\title{
COUPLED SURFACE WATER-GROUNDWATER MODEL TO ANALYZE SUSTAINABILITY OF THE ATASCADERO SUBBASIN
}

\author{
A Thesis presented to \\ the Faculty of California Polytechnic State University, \\ San Luis Obispo
}

\author{
In Partial Fulfillment \\ of the Requirements for the Degree \\ Master of Science in Civil and Environmental Engineering
}

by

Matthew Timothy Klinchuch

June, 2012 
(C) 2012

Matthew Timothy Klinchuch

ALL RIGHTS RESERVED 
COMMITTEE MEMBERSHIP

TITLE:

COUPLED SURFACE WATER-GROUNDWATER MODEL TO ANALYZE SUSTAINABILITY OF THE ATASCADERO SUBBASIN

AUTHOR:

DATE SUBMITTED:

COMMITTEE CHAIR:

COMMITTEE MEMBER:

COMMITTEE MEMBER:
Matthew Timothy Klinchuch

June 2012

Misgana Muleta, Ph. D., P.E.

Shikha Rahman, Ph. D., P.E.

Paul Sorensen, RG, $\mathrm{CHg}$ 


\author{
ABSTRACT \\ Coupled Surface Water-Groundwater Model to Analyze \\ Sustainability of the Atascadero Subbasin \\ Matthew Timothy Klinchuch
}

The Atascadero Subbasin, located on the central coast of California, is a small, hydraulically separated sub-region of the Paso Robles Groundwater Basin. Three local cities operate approximately 40 wells to pump the Subbasin for their entire water supply needs. Past studies have questioned sustainability of the Subbasin as the combined pumping rate by the three cities is nearing the perennial yield of the Subbasin. The studies have been inconclusive as some areas of the Subbasin have seen increases in water table elevation thus questioning the assessment that consumption is nearing perennial yield. The objective of this research was to perform a water balance study for the aquifer and examine sustainability of the Subbasin. Surface water and groundwater models were developed to investigate the interaction between the Salinas River Alluvium Soils and the deeper Paso Robles Formation based on pumping from different shallow and deep wells. Surface water hydrology of the Subbasin was studied using HEC-HMS, and Visual MODFLOW was used to model the aquifer. Both HEC-HMS and Visual MODFLOW was calibrated to improve simulation accuracy. HEC-HMS was used to quantify natural recharge to the aquifer and to simulate streamflow and water level for the Salinas River. HEC-GeoHMS was used to delineate the watershed, create sub-watersheds and channel networks, and to extract sub-watershed inputs that were used to build HECHMS from geospatial data including land use, soil and topography data. Different hydrogeologic layers were defined to represent the alluvium and deeper soils. Results show that currently the Atascadero Subbasin does not appear to be in overdraft as shallow groundwater wells pump Salinas River underflow and the alluvium appears to be providing some recharge to the deeper aquifer. These findings would provide municipal and water managers better understanding of where their water comes from, the effects of their pumping, and could help with developing sustainable management strategies for the Subbasin. 


\section{ACKNOWLEDGMENTS}

I would like to thank my advisor Dr. Misgana Muleta and the rest of my committee Dr. Shikha Rahman and Paul Sorensen.

I would like to thank Dr. Gregg Fiegel for his help and support.

I really appreciate the help and wish to thank the professionals in the field who balanced their busy schedules to help me out - Nels Ruud, Timothy Cleath, and John Neil.

Thank you to several classmates for helping me out along the way, specifically Mike Hopkins and Jake Perry.

Thank you to my Mom and Dad, family and friends for their support during this process.

Thank you to my beautiful bride-to-be for putting up with me finishing this project while also planning for our wedding. 


\section{TABLE OF CONTENTS}

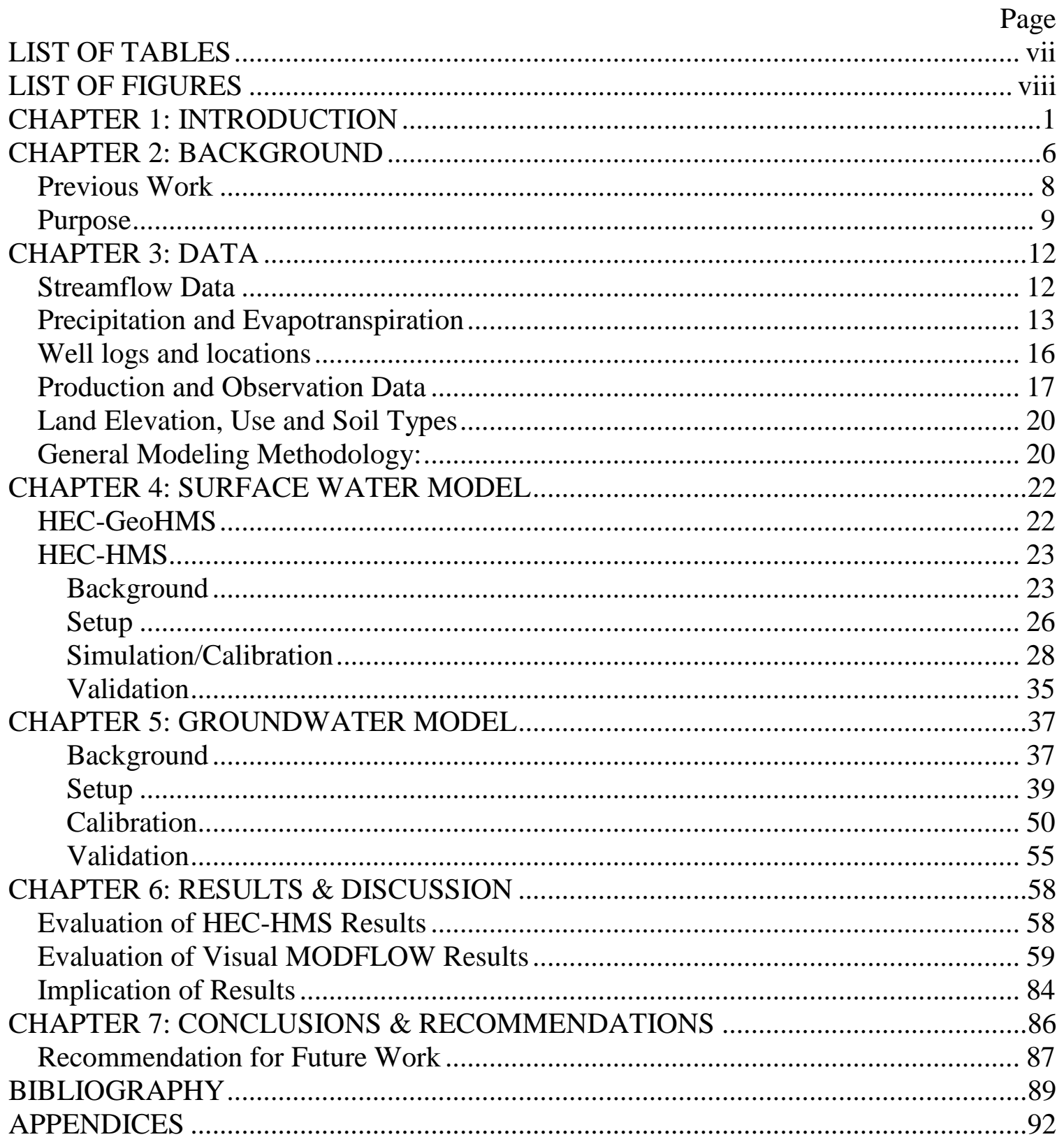




\section{LIST OF TABLES}

Table 1. Initial soil property inputs to the Visual MODFLOW model from Fugro

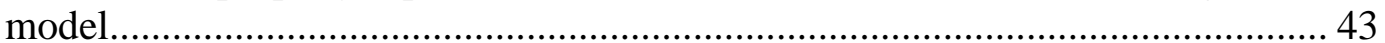

Table 2. Monthly Recharge to groundwater for the year 2004 (HEC-HMS output) ........ 46

Table 3. Comparison of conductivity and storage parameters by soil........................... 55 


\section{LIST OF FIGURES}

Page

Figure 1. Schematic of groundwater well pumping near a stream (USGS)....................... 3

Figure 2. Project Location with hatched Salinas River Watershed overlaying the Atascadero Subbasin portion of the Paso Robles Groundwater Basin. ................... 7

Figure 3. Plot of corresponding precipitation and streamflow in the Atascadero Subbasin for the study period. ......................................................................... 15

Figure 4. Geologic Cross-Section of Atascadero Subbasin (Visual MODFLOW Output)

Figure 5. Combined monthly pumping by Region for a totalized view of

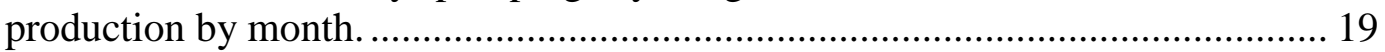

Figure 6. HEC-GeoHMS output after terrain processing. .............................................. 23

Figure 7. Soil Moisture Accounting Algorithm Schematic (HEC-HMS Manual,

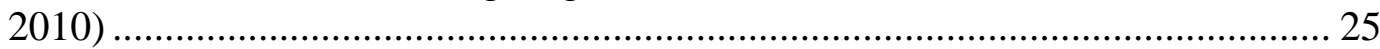

Figure 8. Objective function for HEC-HMS calibration for volume............................... 31

Figure 9. Results for HEC-HMS calibration for volume............................................... 32

Figure 10. Sensitivity results from calibration for volume............................................ 32

Figure 11. Objective function for HEC-HMS calibration for peak flow.......................... 33

Figure 12. Sensitivity analysis for calibration for peak flow........................................... 34

Figure 13. Comparison of observed and simulated streamflow for the calibration period (i.e. for Jan. 2004 to Dec. 2005.) ……………...................................... 35

Figure 14. Comparison of observed and simulated streamflow for 10 year period.......... 36

Figure 15. Visual MODFLOW model domain for the Atascadero Subbasin................... 42

Figure 16. Observation Well Locations for the Visual MODFLOW analysis. ................. 45

Figure 17. Stream package input in Visual MODFLOW model. ...................................... 49

Figure 18. Calculated vs. Observed heads for MODFLOW calibration year 2002.......... 53

Figure 19. Residual distribution for year 2002 model calibration. ................................... 54

Figure 20. Calculated versus Observed Heads for full optimized model. ......................... 56

Figure 21. Residual distribution for full optimized model. ............................................ 57

Figure 22. Head contours and flow direction in Layer 1 in Atascadero in April

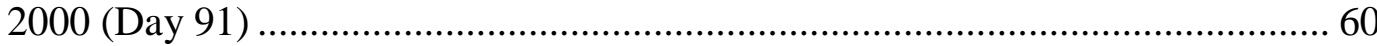

Figure 23. Head contours and flow direction in Layer 1 in Atascadero in October

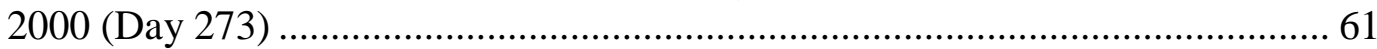

Figure 24. Head contours and flow direction in Layer 1 in Atascadero in April

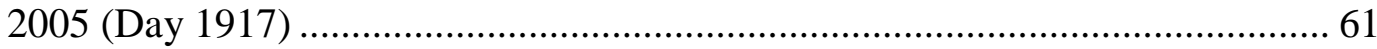

Figure 25. Head contours and flow direction in Layer 1 in Atascadero in October

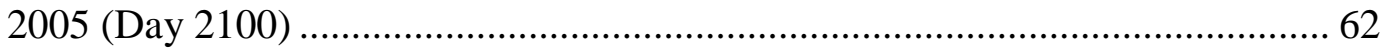

Figure 26. Head contours and flow direction in Layer 1 in Atascadero in April

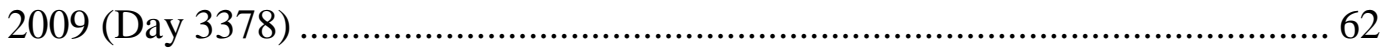

Figure 27. Head contours and flow direction in Layer 1 in Atascadero in October 2009 (Day 3561) 
Figure 28. Head contours and flow direction in Layer 3 in Atascadero in April

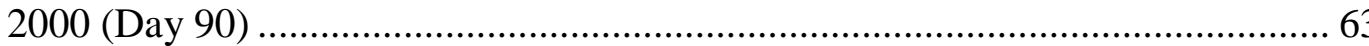

Figure 29. Head contours and flow direction in Layer 3 in Atascadero in October 2000 (Day 273) ........................................................................................ 64

Figure 30. Head contours and flow direction in Layer 3 in Atascadero in April

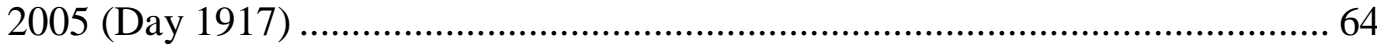

Figure 31. Head contours and flow direction in Layer 3 in Atascadero in October 2005 (Day 2100)

Figure 32. Head contours and flow direction in Layer 3 in Atascadero in April

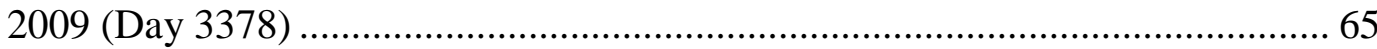

Figure 33. Head contours and flow direction in Layer 3 in Atascadero in October

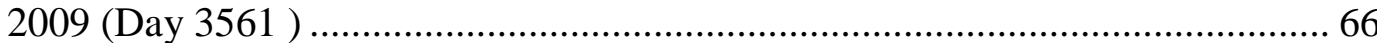

Figure 34. Head contours and flow direction in Layer 1 in Paso Robles in April

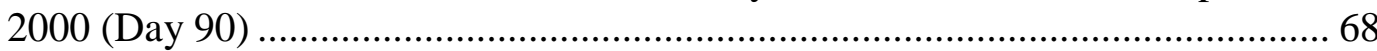

Figure 35. Head contours and flow direction in Layer 1 in Paso Robles in October

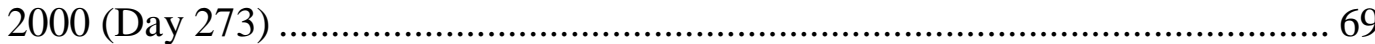

Figure 36. Head contours and flow direction in Layer 1 in Paso Robles in April

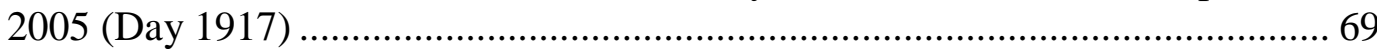

Figure 37. Head contours and flow direction in Layer 1 in Paso Robles in October

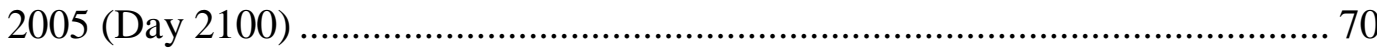

Figure 38. Head contours and flow direction in Layer 1 in Paso Robles in April

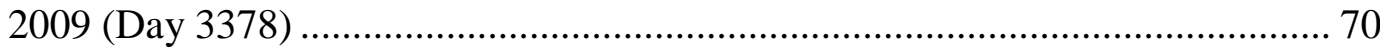

Figure 39. Head contours and flow direction in Layer 1 in Paso Robles in October 2009 (Day 3561) .................................................................................... 71

Figure 40. Head contours and flow direction in Layer 3 in Paso Robles in April

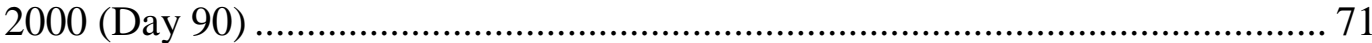

Figure 41. Head contours and flow direction in Layer 3 in Paso Robles in October 2000 (Day 273) ....................................................................................... 72

Figure 42. Head contours and flow direction in Layer 3 in Paso Robles in April

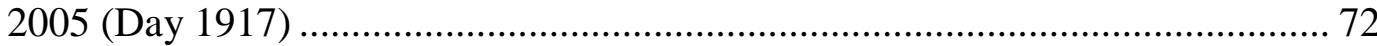

Figure 43. Head contours and flow direction in Layer 3 in Paso Robles in October

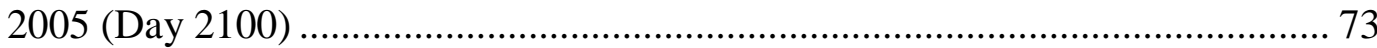

Figure 44. Head contours and flow direction in Layer 3 Paso Robles in April 2009 (Day 3378) ............................................................................................ 73

Figure 45. Head contours and flow direction in Layer 3 in Paso Robles in October

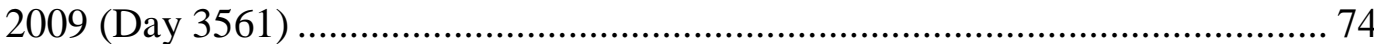

Figure 46. Observed and Simulated head versus time for AMWC 11 ......................... 75

Figure 47. Observed and Simulated head versus time for Davis well ........................... 76

Figure 48. Observed and Simulated head versus time for Platz River well ..................... 77

Figure 49. 10\% increase in pumping in October 2000 showing additional drawdown and influence near Atascadero in Layer 3 ....................................... 79

Figure 50. 20\% increase in pumping in October 2000 showing additional drawdown and influence near Atascadero in Layer 3 ....................................... 79

Figure 51. 10\% increase in pumping in April 2009 showing additional drawdown and influence near Atascadero in Layer 3 
Figure 52. 20\% increase in pumping in April 2009 showing additional drawdown and influence near Atascadero in Layer 3

Figure 53. 10\% increase in pumping in October 2009 showing additional drawdown and influence near Atascadero in Layer 3 ........................................ 81

Figure 54. 20\% increase in pumping in October 2009 showing additional drawdown and influences near Atascadero in layer 3 ..................................... 81

Figure 55. 10\% increase in pumping in October 2005 showing additional drawdown and influence near Paso Robles in Layer 1

Figure 56. 20\% increase in pumping in October 2005 showing additional drawdown and influence near Paso Robles in Layer 1 .................................... 82

Figure 57. 10\% increase in pumping in October 2009 showing additional drawdown and influence near Paso Robles in Layer 1

Figure 58. 20\% increase in pumping in October 2009 showing additional drawdown and influence near Paso Robles in Layer 1 


\section{CHAPTER 1: INTRODUCTION}

Water is a vital resource. In 2005 water use in the United States averaged at 410 billion gallons per day (Bgal/day) and 85\% of that was freshwater (USGS Circular 1344, 2005). This is a very large quantity of water that is in demand by just this country alone. This leads to a great need for better understanding water resources availability and sustainability. Sustainability of water resources has become more questionable in the phases of stressors such as population growth, increased demand for agricultural and urban uses, the need to maintain adequate environmental flows to sustain healthy ecology, potential impacts of human-induced changes such as land development, climate change, and vulnerability of the water infrastructure to natural or intentional disasters.

Freshwater is composed of both surface and groundwater sources. Many water supply systems use a combination of the two sources. Systems that have access to both surface and groundwater tend to be more reliable and sustainable since demand can be satisfied from multiple sources instead of depleting one source. There are some systems, however, that are dependent upon one water source. Usually one source systems that depend on groundwater are located in dryer climates and/or are communities too small to have its own surface water infrastructure. Water infrastructure can be very costly and is usually made up of several components such as storage systems (i.e. dams) and conveyance structures (i.e. channels, pipelines, and pumps) and have associated maintenance costs required for keeping the system and infrastructure up and running. For these reasons many small communities rely on groundwater for most or all of their water 
needs on groundwater, which averages around 350 gallons per day (GPD) for domestic use (AWWA, 1999).

Approximately 79.6 Billion GPD, or 23\% of all freshwater use in 2005 came from pumped groundwater (USGS Circular 1344, 2005). Groundwater supplies several different categories such as public and domestic water supply, water for agriculture and livestock, and other industrial uses. Thirteen percent of all groundwater pumping in 2005 was located in California, the largest of any state (USGS Circular 1344, 2005). 30-40\% of California's water supply is met with groundwater pumping depending upon the water year (California DWR, 2003). This amount is expected to increase with continued growth in population and industry in the state. Increased consumption can lead to several negative impacts on the groundwater supply. Problems associated with over pumping groundwater include: increased pumping costs as water levels drop, pumping wells going dry, reduced surface water, land subsidence, and decreased water quality. With the high possibility of these impacts occurring from over-pumping groundwater, a solution such as integrating surface and groundwater sources needs to be researched and implemented. Understanding the interaction between groundwater and surface water is a topic that fits this need.

Many questions arise amongst engineers, managers, and policy-makers as they decide how to manage and sustain water resources systems. Some of these questions include: "how much water is available?", "how reliable is the source?", and "how can groundwater and surface water be sustained for years to come?" How does a groundwater-surface water system work, specifically, how do they interact with each other? Many of these questions can be answered through research that uses either 
monitoring and/or a modeling approach. For example, the interaction between groundwater and surface water has been previously studied numerous times using monitoring experiments as well as models. Braaten et al. (2003) studied an aquifer in New South Wales. Langhoff et al. (2006) did a study in the Karup catchment in Denmark. Owor et al. (2009) studied the upper Nile Basin in Uganda. Zhang et al. (2011) studied in Northern California. The goal of these studies was to find a greater understanding of the interaction between surface water in the form of a stream, lake, natural or artificial recharge, and the aquifer below.

Analysis of pumping impacts near lakes, rivers, and streams is important because too much pumping can start drawing water flow from both the aquifer and nearby surface water body, as depicted in Figure 1. If the water table is depleted at a well, the flow gradient (direction of flow) changes to flow towards the well instead of downgradient.

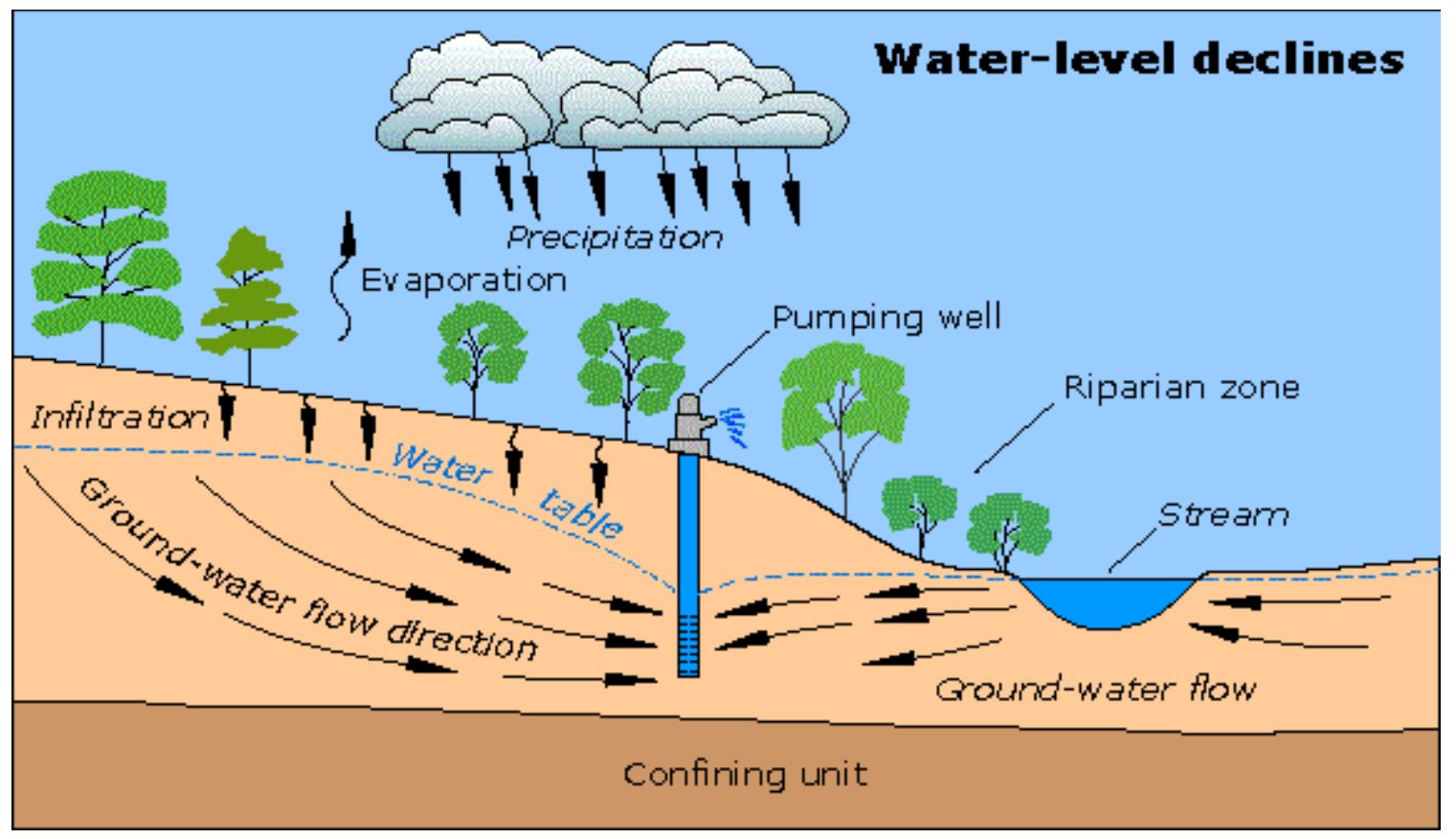

Figure 1. Schematic of groundwater well pumping near a stream (USGS) 
Sustainability is the strategic direction of most water policies today. As the demand for water grows with increasing population, the continued availability of fresh water has been questioned. For this reason, being able to sustain a source for water is very critical. Areas that have groundwater pumping along or near river, like the Atascadero Subbasin, have many interrelated factors that must be considered to successfully sustain the water balance while meeting demand.

Water balance is a method for determining the amount of water entering and exiting a container or volume of water, like a groundwater aquifer. Many inputs and outputs are considered in the mass balance relationship for a groundwater-surface water system. Inputs include recharge from precipitation, intentional recharge, and seepage from streams and lakes. Outputs include evapotranspiration, pumping, and outflow to a stream. The difference between the inflow and outflow is the change in storage of the aquifer. Storage changes throughout a year as the seasons and demand changes. During wet periods, precipitation, recharge, and surface water are more prominent, and pumping demand tends to be less, resulting in a net increase in storage. The opposite occurs in dry periods when surface water and precipitation are not as prevalent and pumping demand increases. Gaining an understanding of these different components is required to determine the dynamics of an aquifer. Once the aquifer dynamics are understood, the sustainability of the aquifer can be assessed.

Many approaches exist in determining and analyzing the dynamics of an aquifer. Two of the most prevalent methods for studying a groundwater aquifer are experimental monitoring of gages and wells or using a computer model. The experimental approach can provide real data but is very time consuming and expensive. Groundwater flows tend 
to be quite slow with velocities measured in days instead of seconds. This leads to needing an extended period of time to retrieve observation data that gives a full picture of the changes that occur. On some occasions new monitoring wells are required to be built, which can lead to increased costs. Modeling, however, can produce reliable results (if properly calibrated) in much less time. Modeling software can simulate a time period very quickly which saves time and money over an experimental monitoring study. For these reasons, the effort to analyze aquifer interactions for this study used modeling software.

This thesis used the Atascadero Subbasin as a case study in analysis of groundwater-surface water interactions. This effort combines two well-known modeling softwares: HEC-HMS by U.S. Army Corp of Engineers for surface water modeling and Visual MODFLOW by Schlumberger Water Services (based on the original U.S. Geological Survey code) for groundwater modeling. The results of this study could possibly help to improve planning and management of the Atascadero Subbasin and to maintain a sustainable future for those dependent on the aquifer. 


\section{CHAPTER 2: BACKGROUND}

Located in Northern San Luis Obispo and Southern Monterey Counties of California, the Paso Robles Groundwater Basin covers an area of approximately 790 square miles. Figure 2 shows a map of the location of the Paso Robles Groundwater Basin. It covers a large portion of the upstream drainage area to the Salinas River. The basin is surrounded by the Santa Lucia Range on the west, the La Panza Range on the south, and the Temblor and Diablo Ranges to the east. A small region of the Paso Robles Groundwater Basin is hydraulically separated by the Rinconada Fault. This inactive fault separates approximately 23 square miles along the Salinas River into a subbasin known as the Atascadero Subbasin (Fugro \& Cleath, 2002). The focus of this study is on the Atascadero Subbasin, also shown in Figure 2. Recharge to the Subbasin is dependent on streamflow of the Salinas River. A vast majority of the aquifer recharge each year is contributed by the River compared to other sources such as infiltration through the land surface from precipitation. 


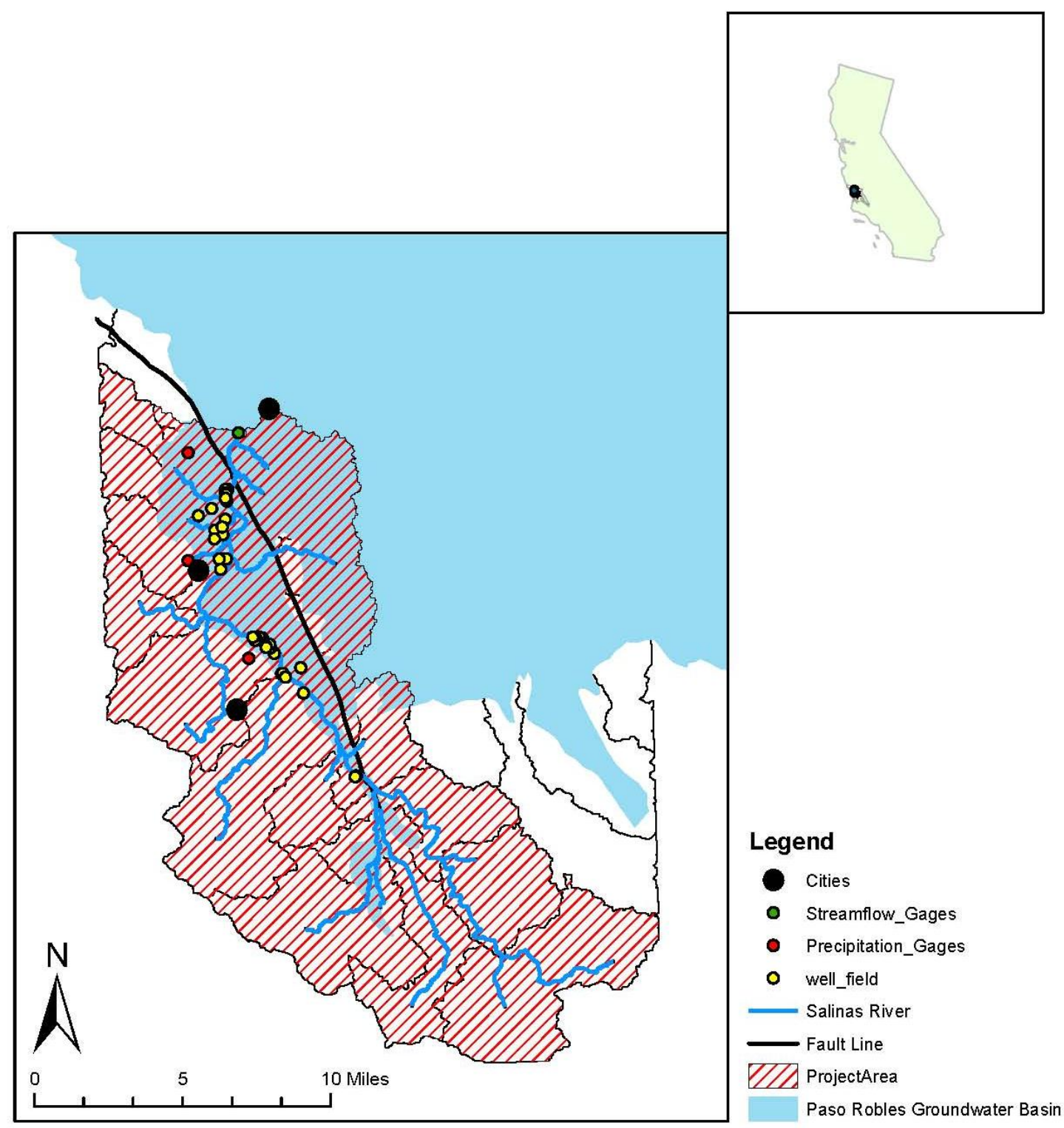

Figure 2. Project Location with hatched Salinas River Watershed overlaying the Atascadero Subbasin portion of the Paso Robles Groundwater Basin.

The cities of Paso Robles, Templeton, and Atascadero rely on the Atascadero Subbasin for their water supply needs. Groundwater pumped from approximately 40 wells in the Atascadero Subbasin is the only water supply used to meet all agricultural, industrial, and residential demands as there are no surface water programs in place for the region at this time. With the entirety of the water supply coming from this one source, sustainability of the aquifer needs to be examined. 


\section{Previous Work}

In 2002, Fugro West, Inc. and Cleath and Associates completed a report on Phase One of a study of the Paso Robles Groundwater Basin. The purpose of the study was to investigate the hydrogeologic conditions and quantify the water supply capability of the basin (Fugro \& Cleath, 2002). The Phase One study covered several aspects of the aquifer to be modeled in a subsequent Phase Two. During the Phase One study, the two companies defined the spatial area and depth of the groundwater basin, determined a water balance, and checked water quality in different regions of the basin. The report took into account several water wells and monitoring wells, precipitation gauges, stream gauges, land uses, and population water demand (Fugro \& Cleath, 2002). All this information was used to determine the hydraulic conductivities for the basin soils, a water balance, and perennial yield estimates for the Paso Robles Groundwater Basin as a whole and the Atascadero Subbasin. From the study, areas of concern were found which included the Atascadero Subbasin. The problem seen with the Atascadero Subbasin was that pumping data were getting closer to the estimated perennial yield (maximum annual pumping capacity) of 16,500 acre-feet per year (AF/yr). The recommendation from findings of this Phase One report was to setup a model to analyze the whole basin for future management purposes (Fugro \& Cleath, 2002).

In 2005, Fugro West completed Phase Two of the Paso Robles Groundwater Basin Study. The model was setup and calibrated based on the data gathered in the first report. The model reaffirmed the problem areas found in the first study. Scenarios were then tried that estimated future demands of the water to determine when the Basin reached and/or surpassed its perennial yield. After determining when pumping would 
reach the level of overdraft for the basin, different methods to appease the level of demand were made. The main recommendation was to use water from Lake Naciemento in the Naciemento Project that is under construction (Fugro \& Cleath, 2005).

Another modeling study was completed in September 2009 for the City of Atascadero and Atascadero Mutual Water Company (AMWC) by GEOSCIENCE Support Services Inc (GEOSCIENCE, 2009). This model was completed covering a portion of the Atascadero Subbasin around the City of Atascadero focusing on AMWC well 2A. The goal of the 2009 study was to evaluate the effects on groundwater quality with increased effluent discharge from a wastewater treatment facility in Atascadero. This model was largely based upon the Fugro MODFLOW model, with addition of newer data and using the MT3DMS solute transport package to analyze total dissolved solids and chloride.

\section{Purpose}

Previous studies and observations by water controllers in the area noticed that the Subbasin was nearing its perennial yield for pumping in the early 2000's. Questions regarding the sustainability of the Subbasin arose and investigations were made into finding possible solutions to meet the demand but also prevent the deterioration of the aquifer. Controversy arose when the investigation discovered groundwater surface elevation data that showed the water surface elevation was staying consistent or rising in some areas. The expectation was to see the depth to water increase as the pumping volume neared the perennial yield (Sorenson, 2010). Previous reports and observed data show that the shallow wells in the Subbasin were pumping Salinas River underflow instead of drawing from the groundwater aquifer and there must be an interaction 
between the shallow river alluvium and the deeper Paso Robles Formation (soil of the deep aquifer).

Overall the 2005 Fugro groundwater model is very good for management of the entire basin, but it is too large to determine the finer aspects. The Atascadero Subbasin makes up approximately $3 \%$ of the entire basin and the interactions occurring are on much too small a scale to obtain accurate estimates from the large model. Building from these previous reports a smaller model was developed in Visual MODFLOW focusing solely on the Atascadero Subbasin. The analysis was performed using more recent data covering the span of January 1, 2000 to December 31, 2009. This ten year study period essentially begins where the previous model ended and generates a model that represents the existing conditions of the Atascadero Subbasin to provide a more definitive explanation of the characteristics of the Subbasin.

Two goals were established for this study:

\section{Determine the interaction between the Salinas River Alluvium and the Paso}

Robles Formation. Determining how groundwater flows between these two geologic formations will help in understanding of the groundwater dynamics in the Subbasin. Only $21 \%$ of the Subbasin is made up of the Alluvial soils, but this fraction of the soils accounts for $60 \%$ of the recharge (Fugro \& Cleath, 2010). These numbers show that much of the recharge of the groundwater aquifer is dependent on the interaction between the shallow alluvium and the Paso Robles Formation. A model that can accurately analyze the effects of the groundwater pumping along with the flow in the Salinas River will be an important tool in 
understanding how this interaction works and give a general idea of when recharge will occur and when it will not.

2. Determine the effect of the shallow wells on the Atascadero Subbasin. Many believe the discrepancy between the groundwater pumping rates and water elevation levels are due to the shallow pumping wells, such as City of Paso Robles' Thunderbird Wells, in the Subbasin. Knowledge of the area indicates that shallow wells are pumping underflow from the Salinas River as opposed to the groundwater aquifer, but presently no study has quantified these results. Building a model to analyze the Subbasin will improve understanding of the interaction between pumping wells and the Salinas River. There are several shallow wells in the region operated by Atascadero, Templeton, and the Thunderbird Wells in Paso Robles. The goal of this study is to determine the impacts of these wells in the Salinas River alluvium in the Subbasin.

By accomplishing these goals the water purveyors controlling groundwater pumping wells will be able to understand the impact of their pumping on the Subbasin, and design future planning and management approaches to minimize adverse effects on the aquifer and the Salinas River. 


\section{CHAPTER 3: DATA}

Several forms of input data are required to build a reliable model that will provide meaningful results for the parties involved. This study required an extensive data gathering period. Salinas River streamflow data, regional precipitation and evapotranspiration data, well logs and location, well production data, ground and surface water elevation, soil types and land use were the different types of information gathered for the mapping and analysis. The spatial data was combined to form a base map generated in ArcMap, a Geographic Information System (GIS) software that allows visual mapping. GIS was used to display several of the region's characteristics such as topography, soil types, rivers, earthquake faults, and monitoring locations (see Figure 2). These data are discussed below.

\section{Streamflow Data}

Flow through the Salinas River is a key component to the analysis of the Atascadero Subbasin as water in the alluvial soils makes up as much as $60 \%$ of the annual recharge to the groundwater (Fugro, 2010). The main parameters needed from the river data are the flow in the river and the stage height, or depth of flow in the river. These data are used in a mass balance analysis effort to determine percolation for recharge. Depth of the water is a parameter is applied in both the surface water analysis of HEC-HMS and the groundwater analysis in Visual MODFLOW analysis. Depth of flow has potential to be a key component in the study. If a link between the surface water and groundwater is found, depth could be important in finding whether water is being 
recharged or removed from the aquifer. In the Subbasin there are two stream flow stations, the Paso Robles Salinas River Gage (downstream) and the Santa Margarita Salinas River Gauge (upstream). The Salinas River Gage in Paso Robles is near the outlet of the Atascadero Subbasin. The gage is maintained by the California Department of Water Resources (DWR) and the U.S. Geological Survey (USGS). Data were recorded at this point for several decades, and provide a complete daily dataset that encompasses the study period. The Salinas River Gage in Santa Margarita is located downstream of the Santa Margarita Reservoir and is maintained by San Luis Obispo County. Data from this station records the flow released from the reservoir into the Salinas River (Graton, 2010). Figure 3 shows net daily streamflow at the Paso Robles gage location. Net daily streamflow was determined by subtracting corresponding Santa Margarita flows from the Paso Robles Gage values.

\section{Precipitation and Evapotranspiration}

San Luis Obispo County has several precipitation stations in the model area. For this project there are three gauges with complete precipitation history during the study period for the analysis. The gauges chosen are: Paso Robles \#10, Templeton \#196, and Atascadero Mutual Water \#34 (Graton, 2010). These gauges had daily rainfall data for the study period (January 2000 to December 2009). More than one gauge was chosen for the region due to spatial precipitation variability in the Subbasin. In Paso Robles the average annual rainfall is approximately 15 inches and for Atascadero and Templeton the average is above 17 inches. Utilizing the different precipitation stations allows for building a model that can more accurately analyze the spatial intricacies of the study 
region. Figure 3 also includes average daily precipitation. The average used in this study was calculated using the daily precipitation data from the three stations.

Evapotranspiration data came from the California Irrigation Management Information System (CIMIS) which is run by the Department of Water Resources Office of Water Use Efficiency. The CIMIS website was developed in 1982, with the help of UC Davis, to "assist irrigators with managing their water resources efficiently" (CIMIS, 2011). Station Atascadero \#163 was used to estimate monthly values for evapotranspiration for the study region since this was the only CIMIS station available in the area. The evapotranspiration data are available at daily time increments. Monthly averages were calculated for each month from the daily readings available. 


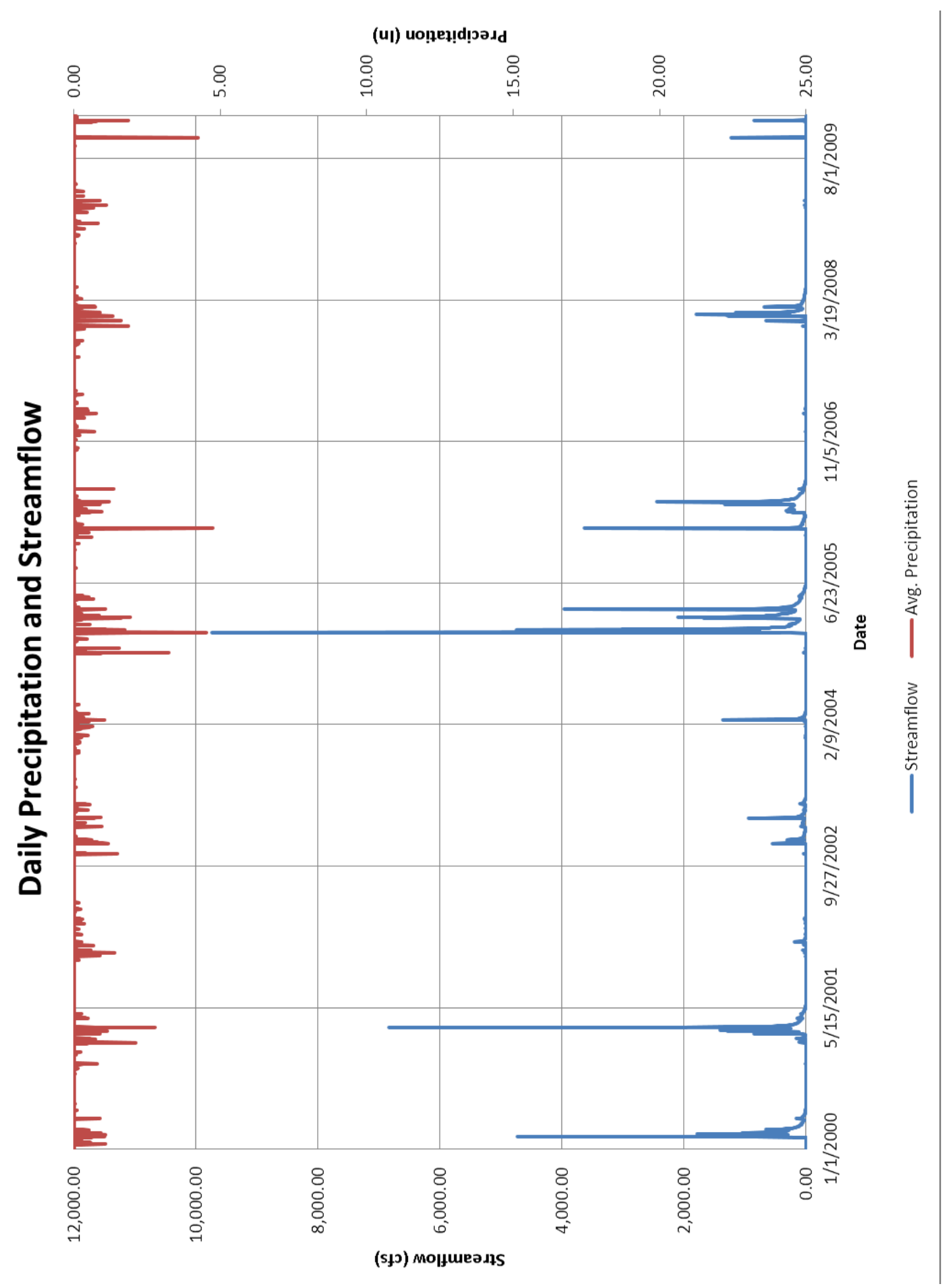

Figure 3. Plot of corresponding precipitation and streamflow in the Atascadero Subbasin for the study period. 


\section{Well logs and locations}

The purpose of the well logs is to determine the different geologic layers to be modeled in Visual MODFLOW. Besides ground surface elevations, the elevations for the bottom of the first and second layers and the bottom impervious layer are needed. These logs show the soils bored into during the drilling of water wells and give the approximate depths at which the soils were found. The most useful logs are from deeper wells as they differentiate soil for a much greater span (Ruud, 2011). The shallow well logs are not able to give as good a picture of the entire depth needed for the model, but are helpful in determining transition between the shallower layers such as the shallow alluvium to clay that occurs throughout the Atascadero Subbasin.

Well logs from the three agencies, City of Paso Robles, Templeton Community Services District, and Atascadero Mutual Water Company, were obtained for most of the water wells located in the Atascadero Subbasin. There are approximately 40 groundwater wells in the region along with several monitoring wells. Four of the logs are for the Thunderbird Wells in Paso Robles. These are the only pumping wells Paso Robles operates in the Subbasin. They produce a major portion water for the City of Paso Robles. In Templeton, the Templeton Community Service District (CSD) operates 14 wells that produce the needed water. Atascadero has the most wells of the three agencies, with over 20 wells operated by the Atascadero Mutual Water Company. This company supplies the water to the City of Atascadero and surrounding areas.

After reviewing well logs and consulting with Paul Sorensen of Fugro West Inc., the layer thicknesses were set to be approximately 100 feet for Layer 1 (mostly Salinas River alluvium), approximately 50 feet for Layer 2 (mostly older alluvium and clay), and 
the remaining depth of approximately 350 feet was for Layer 3 (Paso Robles Formation). The Paso Robles Formation has potential to be split into two separate layers, but the Formation is extremely heterogeneous such that determining where to split would be difficult and not result in significant changes to accuracy (Sorensen, 2010).

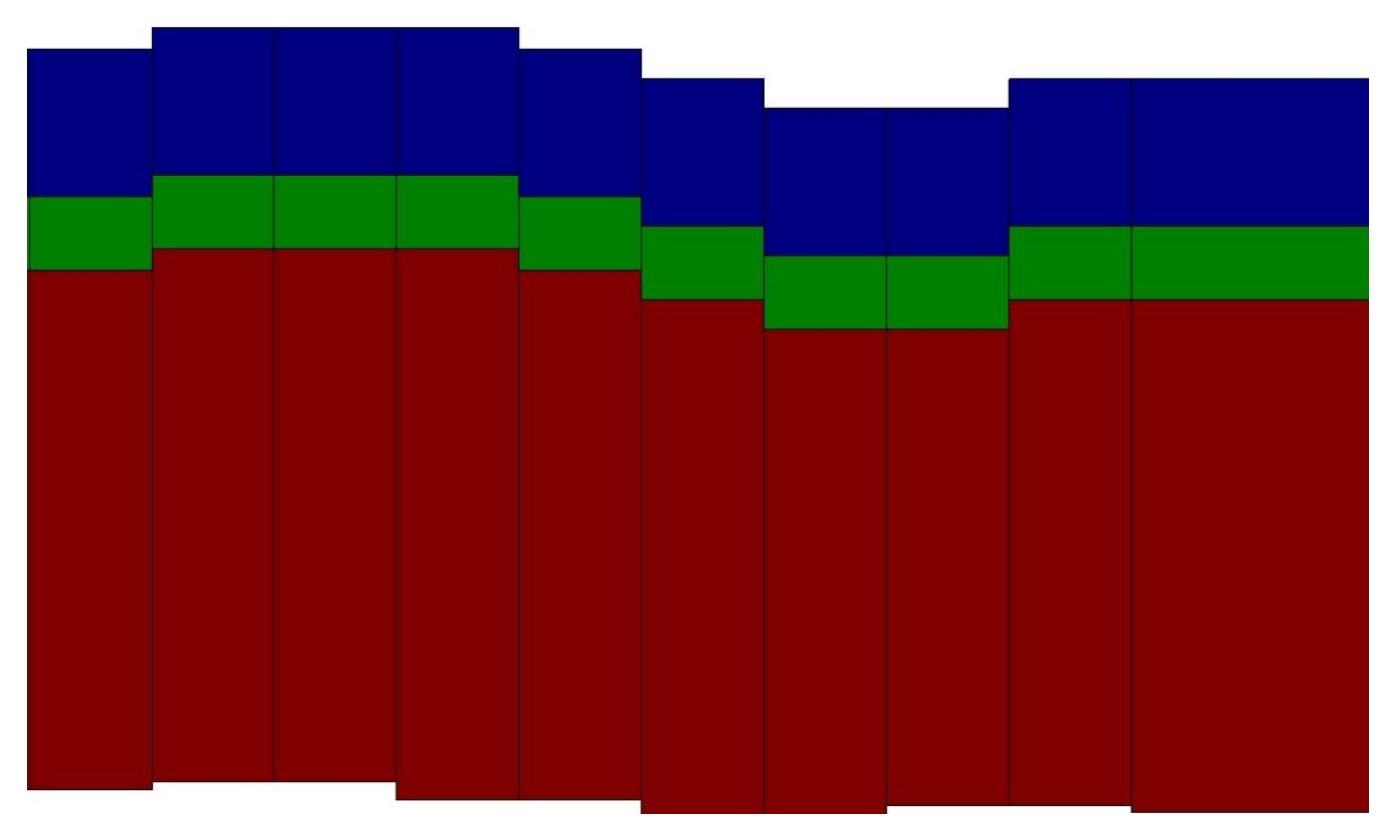

Figure 4. Geologic Cross-Section of Atascadero Subbasin (Visual MODFLOW Output)

\section{Production and Observation Data}

Well production and water elevation data came from the three agencies that control the pumping wells. The City of Paso Robles, Templeton Community Services District and Atascadero Mutual Water Company supplied the data, which are in a monthly format, for the ten year design period. Pumping data include both totalized well production and production rate per well. The production rate per well data is a data input for the MODFLOW model in units of gallons per day (GPD). Water elevation data were used in comparison to the simulated results during calibration of the MODFLOW model. 
Figure 5 shows monthly pumping for the study period. The production data from the three agencies is combined to jointly show the total pumping in each month and show a breakdown of pumping by agency. Looking at Figure 5, there is a cyclical trend that shows more pumping in dry periods (i.e. summer months) and less in wet periods (winter months). This cycle shows the large water demand in the dry summer months.

There is an assumption made by using the pumping data from only these three agencies for the model. There are more wells in the Atascadero Subbasin that are private landowner water wells. Most of these private wells are not regularly monitored and questions would arise about the reliability and quantity of the available information. For this reason these wells were left out of the analysis. Municipal well production from the City of Paso Robles, Templeton CSD, and AMWC make up the vast majority of the pumping but pumping of private wells could create a slightly noticeable difference in total groundwater pumped out of the Subbasin. 


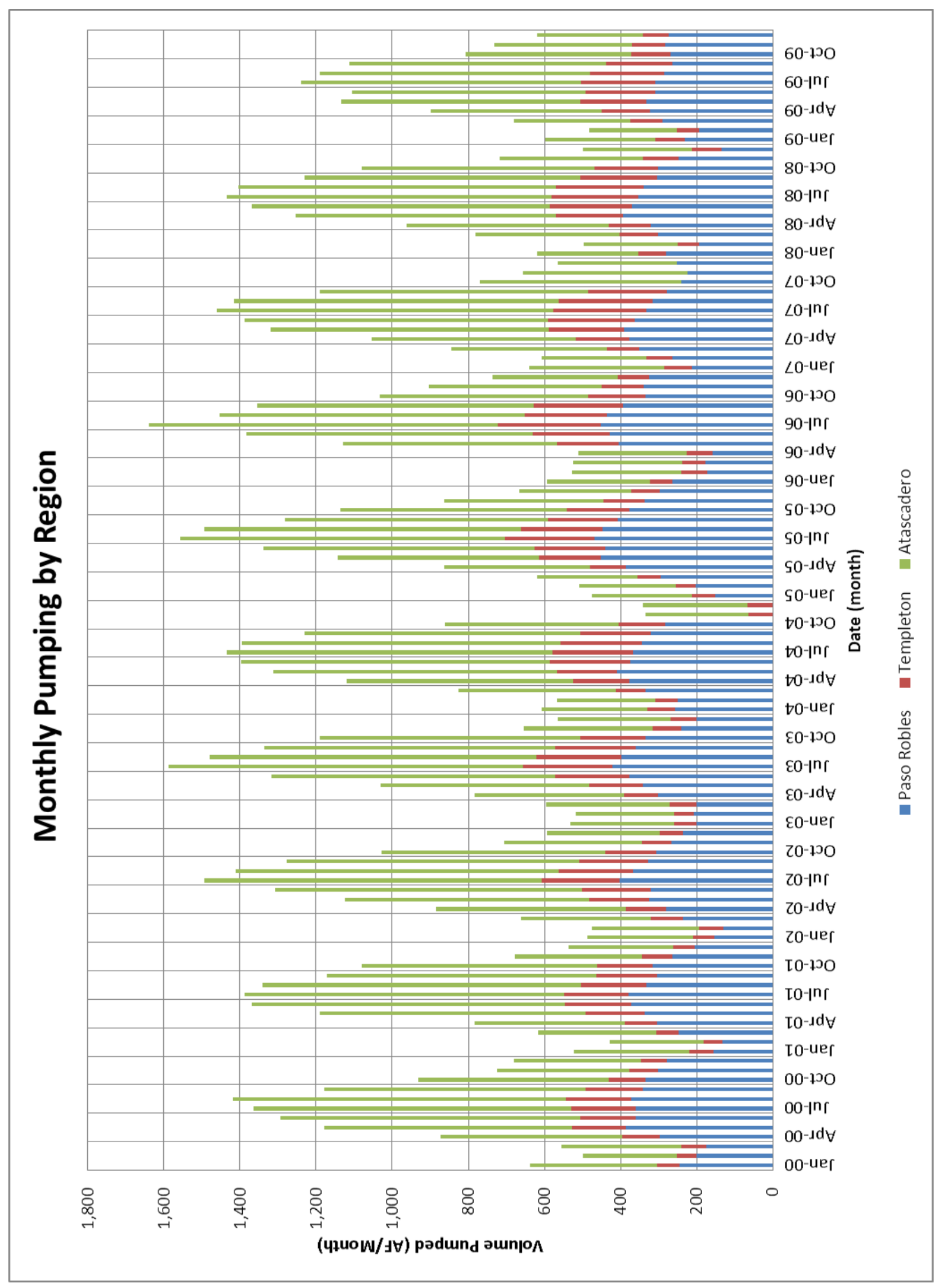

Figure 5. Combined monthly pumping by Region for a totalized view of production by month. 


\section{Land Elevation, Use and Soil Types}

Land elevation and land use data was obtained online from the USGS Seamless Data Warehouse (http://seamless.usgs.gov/). Land elevation is needed for determining the ground surface elevations for both HEC-HMS and Visual MODFLOW, as well as the layer elevations in Visual MODFLOW. The National Elevation Dataset (NED) with 1/3 arc second accuracy was used for both models. A 1/3 arc second is approximately 10 meters (30 feet) in length. This level of accuracy was chosen to allow for more precision in the watershed delineation process to show the elevation difference between the valley floor and surrounding hills and mountains. The Seamless Data Warehouse also has impervious surface data available. Impervious surface data are needed in the HEC-HMS model for determining runoff.

Soil type data was obtained from the Natural Resources Conservation Service Soil Data Mart (http://soildatamart.nrcs.usda.gov/). This is a soil database known as Soil Survey Geographic (SSURGO). The soil type data were used for inputs to both models. The data were used in determining soil runoff and percolation characteristics for the HEC-HMS model and for soil property characteristics such as hydraulic conductivity and storage for the groundwater model.

\section{General Modeling Methodology:}

Several types of software were used for the different stages of the research. The majority of the analysis was completed in HEC-HMS and Visual MODFLOW, but setup was completed using GIS (as mentioned in the previous chapter) and a HEC-HMS extension package known as HEC-GeoHMS. Chapter 4 and 5 will discuss the 
background, model setup/process for each of the three software packages used, and calibration and validation results for the HEC-HMS and Visual MODFLOW models.

Calibration and validation were performed for both the surface water and groundwater models. These two steps are important to modeling as it confirms the reliability and estimation ability of a model. A calibrated and validated model also has more credibility because if it matches well with observed data, then it can be assumed the results produced from the model are more reliable. To satisfy the goals of this study the model was calibrated to fit existing data so that the conclusions made from the results can be credible. 


\section{CHAPTER 4: SURFACE WATER MODEL}

\section{HEC-GeoHMS}

The first data package used for the analysis was the HEC-HMS add-on package HEC-GeoHMS (Hydrologic Engineering Center - Geospatial Hydrologic Modeling System Extension) produced by the U.S. Army Corps of Engineers and is available with the GIS software, ArcMap. HEC-GeoHMS creates background map files, basin model files, meteorologic model files, and grid cell parameter files that are then utilized by the HEC-HMS model (Fleming \& Doan, 2009). The files relevant to the surface water analysis of this study are the basin model files. The basin model files contain data for physical properties of the soil and soil types as well as data for hydraulic elements (subbasins, river junctions, and river reaches) and their connectivity (Fleming \& Doan, 2009).

Basin model files are created by taking input elevation data, soil type data, and impervious surface data, and land use data. HEC-GeoHMS has a sequence of steps for terrain processing that are followed to recreate the basin for the Salinas River Watershed. The output is a watershed made up of sub-watersheds (subbasins) and river channels. After the terrain processing is complete, HEC-GeoHMS helps with determining hydrologic parameters by compiling the elevation, land use, and impervious data from USGS and the soil data from the NRCS into a table that gives the curve number, percent impervious area, and river reach routing parameters used by HEC-HMS (Fleming \& Doan, 2009). The figure below shows the output produced for the Salinas River 
Watershed surrounding the Atascadero Subbasins. After this process was complete, data were imported into HEC-HMS for running the simulation.

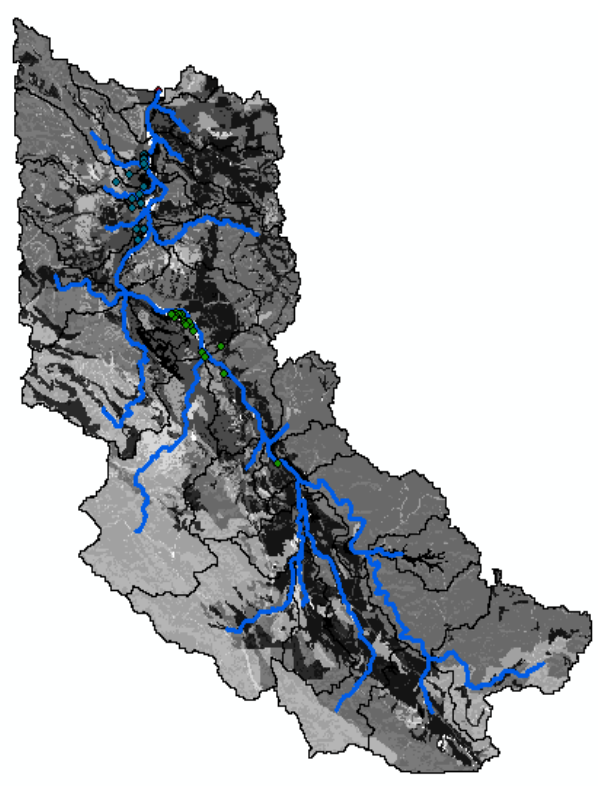

Figure 6. HEC-GeoHMS output after terrain processing.

\section{HEC-HMS}

\section{Background}

Hydrologic Engineering Center - Hydrologic Modeling System (HEC-HMS) is software developed by the U.S. Army Corps of Engineers and has an extension tool bar in the GIS software ArcMap (Scharffenberg \& Fleming, 2010). The HEC-HMS Model is used in this study for the surface water simulation of the Salinas River flows. The purpose of the simulation is to determine the flow to calculate stage height and determine the amount of water percolating to the aquifer along the length of the Salinas River and surrounding watersheds based on precipitation during the study period January 1, 2000 to December 31, 2009. This analysis is beneficial in understanding the surface water impacts to the water budget in the Subbasin. 
As part of this surface water simulation to determine the amount of water percolated to the groundwater from the Salinas River and surrounding watershed a rainfall-runoff package in HEC-HMS known as Soil Moisture Accounting (SMA) was used. This package was chosen because a continuous hydrologic model was needed rather than an event model. A continuous model accounts for a watershed's soil moisture balance over a long-term period as is suitable for simulating daily, monthly, and seasonal streamflow (Fleming \& Neary, 2004). The SMA package allows for moisture accounting for complete simulation of the ten year study period.

SMA conceptualizes potential path of rainfall into five zones (Fleming \& Neary, 2004). These zones can be seen in Figure 7, and represent (in descending order), canopy interception storage, surface depression storage, soil profile storage, groundwater 1 and groundwater 2 storage (combined to one groundwater storage zone in schematic). The parameter of interest is percolation from the soil profile to groundwater. The percolation results are chosen instead of the soil infiltration data because the SMA process also accounts for soil storage and evapotranspiration. The amount of water percolated to the groundwater is dependent upon the moisture of the soil and will not always be the same as the soil infiltration rate. Soil infiltration and percolation to groundwater will only be the same when the soil is saturated after extended wet periods. Percolation results from the HEC-HMS simulation were input into Visual MODFLOW as recharge. Since the SMA method accounts for evapotranspiration, this information is not input into the Visual MODFLOW model to avoid double counting. 


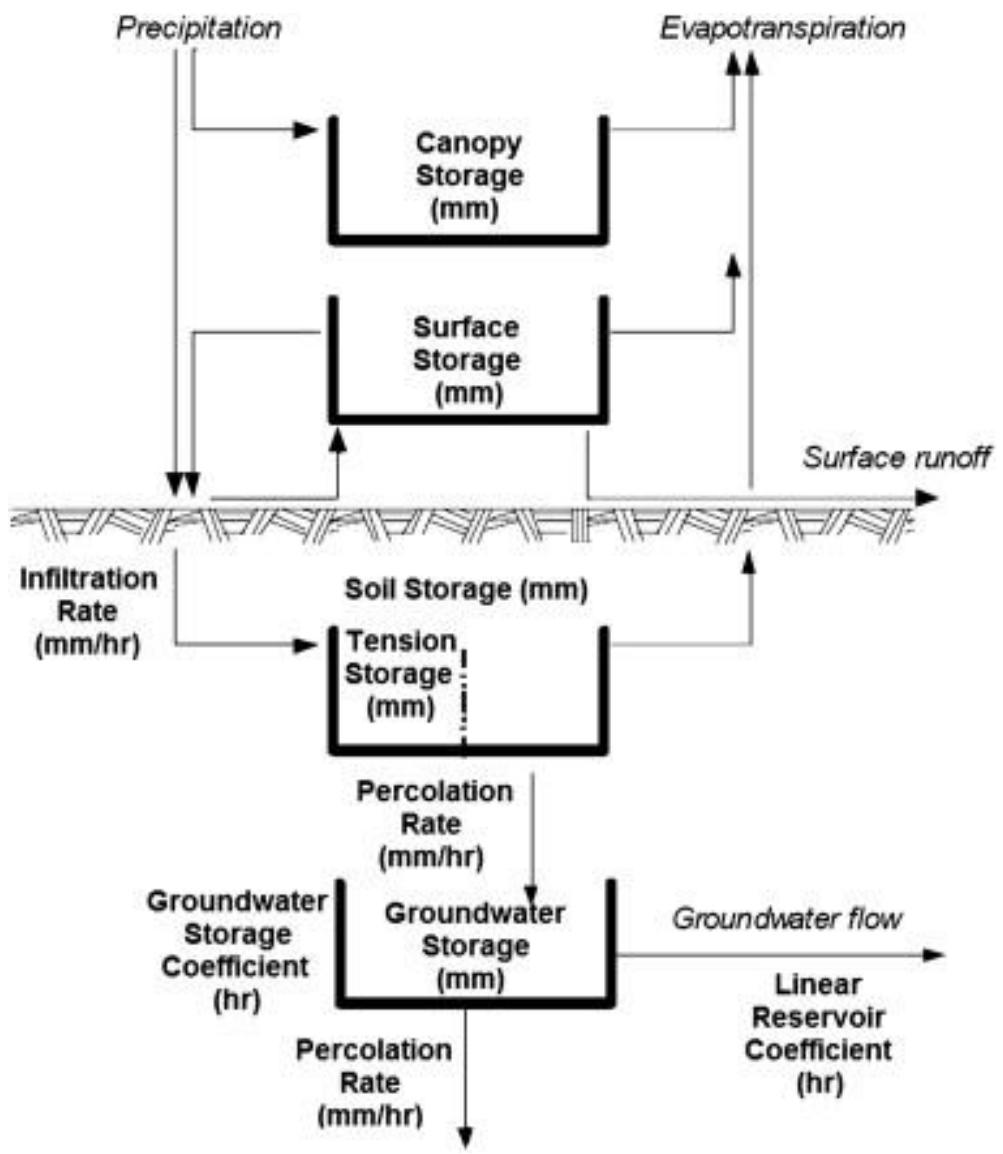

Figure 7. Soil Moisture Accounting Algorithm Schematic (HEC-HMS Manual, 2010)

SMA has 12 parameters that need to be determined for the sub-watersheds before simulating rainfall-runoff relationship of the watershed. These parameters represent: canopy interception storage, surface depression storage, maximum infiltration rate, maximum soil storage, tension zone storage, soil zone percolation rate, groundwater 1 percolation, groundwater 1 and 2 storage depths and storage coefficients, and evapotranspiration. Precipitation and evapotranspiration data came from the San Luis Obispo County and CIMIS stations mentioned in the previous chapter. Initial or baseline values of the other parameters were determined using GIS as described in the previous section. 
The SMA software has helpful tools that allow the inputs to be adjusted for seasonal change (Fleming \& Neary, 2004). Utilizing these tools the surface water model can be adjusted for the parameters to better fit the wet or dry periods that occur throughout the year. These adjustments help minimize model error by fitting the parameters to a shorter time period rather than creating an annual average that is a fit of both wet and dry periods.

To estimate the flow in the Salinas River, the Lag Routing Method was selected for the river reach segments. This is a method that represents translation of flood waves and does not include any representation of attenuation or diffusion processes (Scharffenberg \& Fleming, 2010). The Lag Routing Method was chosen for simplicity in translating the water in the river from upstream to downstream. Although this method is best suited for short stream segments with predictable travel time (Scharffenberg \& Fleming, 2010), for the purposes of this study the method was deemed adequate and this assumption is confirmed through the calibration and validation process shown in the next sections. The only parameter is the lag time in minutes. HEC-HMS delays the inflow in a reach by the length of time specified for lag in the river reach and then the flow becomes outflow (Scharffenberg \& Fleming, 2010).

\section{Setup}

The HEC-HMS model was built by forming and recreating the sub-watersheds and Salinas River using the HEC-GeoHMS described previously. After the delineation of the sub-watershed and river reach shapes and properties the information was exported from HEC-GeoHMS to HEC-HMS. The imported HEC-HMS model receives subwatershed characteristics such as area, slope, infiltration parameters, river routing 
parameters, and sub-watershed-stream network connectivity information created by the HEC-GeoHMS program. Additional watershed data that are needed to develop the HECHMS model were then specified.

The additional inputs included precipitation, evapotranspiration and historical streamflow for the Salinas River. Precipitation and Salinas River flow data are input as time-series data controls. Time-series data are used for specifying time dependent data that comes from different gage types. HEC-HMS can accept several different types of time-series data that range from precipitation and discharge (used in this study) to windspeed, snow water equivalent, crop coefficient, and concentration options (Scharffenberg \& Fleming, 2010). The required information for time-series input are the start and stop times and dates, the time interval between readings, and the data values. The time interval can vary from one minute to one day, with several options in between (Scharffenberg \& Fleming, 2010). Both precipitation and flow time-series data for this analysis were input as daily data from midnight (00:00) January 1, 2000 to midnight January 1, 2010.

HEC-HMS also has meteorological controls to define and format (e.g., observed vs. statistical rainfall) and spatial pattern (e.g. gridded or gauge location based) of precipitation and evapotranspiration data. This control allows for different methods for analyzing and applying precipitation to a watershed. For precipitation data, for example, four methods are supported: specified hyetograph, gage weights, Thiessen Polygons, and gridded precipitation (Scharffenberg \& Fleming, 2010). The specified hyetograph (i.e., observed rainfall pattern) was selected for this study. Using this method, a precipitation gage was specified for each sub-watershed. Based on proximity criteria, the Paso Robles 
\#10 data were applied to Paso Robles sub-watersheds to the north (or downstream on the Salinas River). The Templeton \#196 data were applied just to the south of the Paso Robles \#10 region around the town of Templeton, and the Atascadero Mutual Water Company \#34 gage data were applied to the southern sub-watersheds (upstream area of Salinas River). Like precipitation, four options are available to specify evapotranspiration input, which include: specifying no evapotranspiration, monthly average, Priestly-Taylor and Gridded Priestly-Taylor (Scharffenberg \& Fleming, 2010). The monthly average method is used for this study with the calculated monthly evapotranspiration rates from the Atascadero \#163 CIMIS Station applied to all subwatersheds.

\section{Simulation/Calibration}

After all model inputs are assigned, there is one more step before starting simulations, which is setting the Control specifications. The Control specifications determine when a simulation begins and ends and the time step for calculations. The Control Specification for this study spans from January 1, 2000 to December 31, 2009 with a time increment of one day. Other Control specifications were set for the calibration attempts. The calibration Control specifications are shorter than the full analysis period to minimize computational demand. Since calibration is an iterative process to minimize an objective function (Fleming \& Neary, 2004), trying to calibrate for the full model period could take a significant amount of time. An initial simulation was performed after model setup to obtain a base point for the calibration to start from. After the calibration and validation is complete, the model was simulated again for the 
entire period and the flows used to derive the river/stream boundary inputs to the Visual MODFLOW model.

HEC-HMS has a built-in optimization package for calibrating models (Fleming \& Neary, 2004; Scharffenberg \& Fleming, 2010). To calibrate, an optimization trial is developed by selecting a previous simulation trial wished to be calibrated and the observed dataset trying to be matched. Once the optimization trial is created several parameters can be chosen for the software to use during the calibration process. The twelve parameters of the SMA and river lag times were used to calibrate the HEC-HMS model. The goal of the calibration is to identify optimal value of model parameters (i.e., non-measurable inputs that conceptually describe rainfall runoff process of the watershed) so that model-simulated streamflow closely matches observed streamflow for the watershed.

Calibration was performed using data from January 2004 to December 2005. This period was selected as it contains the typical rainfall pattern of the area. Two types of calibration runs were completed for the two year time period of January 2004 through December 2005 with a time interval set at one hour for better resolution of the daily data. The first calibration attempt aimed at reducing the discrepancy in volume of streamflow simulated by HEC-HMS and the volume of observed streamflow at the Paso Robles gage. The second calibration was aimed at closely matching observed and simulated peak flows. The objective function for the volume calibration was set to Percent Error in Volume. This objective function ignores timing considerations to reduce the difference in total volume over the calibration period (Scharffenberg \& Fleming, 2010). The objective function for the peak flow calibration was Sum of Absolute Residuals. This 
objective function gives equal weight to residuals resulting from high and low flows in an effort to reduce the total residuals (Scharffenberg \& Fleming, 2010). Reduction of residuals means the observed and simulated flows are forced to get closer. The mathematical equations that describe these two error functions are listed below. Percent Error in Volume:

$$
Z=\frac{q_{s} t-q_{o} t}{q_{o} t} \times 100
$$

where

$\mathrm{Z} \quad$ is the percent error in volume listed as a percentage

$\mathrm{q}_{\mathrm{s}}(\mathrm{t}) \quad$ is the volume of runoff simulated from HEC-HMS at a given time $(\mathrm{L})$

$\mathrm{q}_{\mathrm{o}}(\mathrm{t}) \quad$ is the observed runoff from historical data at a given time (L)

Sum of Absolute Residuals

$$
Z={ }_{i=1}^{N Q} q_{o} i-q_{s} i
$$

where

$\mathrm{Z} \quad$ is the percent error of the objective function (L)

$\mathrm{NQ} \quad$ Is the number of computed hydrograph oordinates

Qo (i) Is the observed flow from historical data(L)

$\mathrm{Q}_{\mathrm{s}}(\mathrm{i}) \quad$ Is the simulated flow from HEC-HMS (L)

Calibration for runoff volume was performed first and it produced very good results. The resulting objective function was $0 \%$ difference between the simulated and observed flow volumes at the Paso Robles stream gage on the Salinas River. The model adjusted the SMA parameters for each subbasin (sub-watershed) through multiple 
iterations to identify optimal SMA parameter values. The sensitivity analysis shows that four of the calibrated parameters (groundwater 2 storage coefficient, soil percolation rate, groundwater 1 storage coefficient and surface capacity) resulted in larger changes in streamflow when that parameter value was changed. The groundwater 2 storage coefficient was the most sensitive at $+74.11 \%$. This means that for every $1 \%$ change in the parameter (groundwater 2 storage) a $74.11 \%$ change occurred in the error function resulted (Scharffenberg \& Fleming, 2010). Increasing the storage coefficient for groundwater level 2 shows that there was originally more simulated runoff than observed and more water ought to be infiltrating into the soil than becoming runoff. The following figures show outputs from the HEC-HMS calibration for volume.

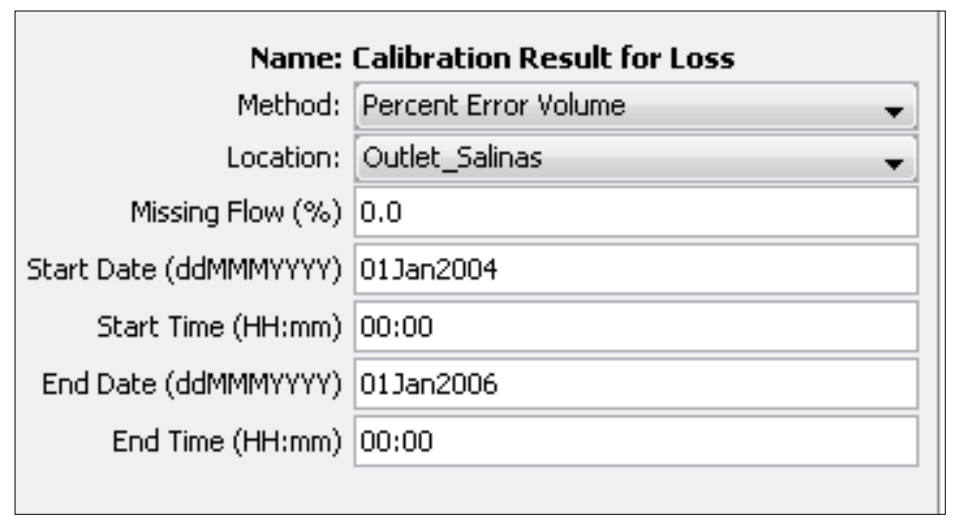

Figure 8. Objective function for HEC-HMS calibration for volume. 


\begin{tabular}{|c|c|c|c|c|}
\hline \multicolumn{4}{|c|}{ 四 Objective Function Results for Trial "Calibration Result for Loss" } & 口 國 $\mathbf{x}$ \\
\hline \multicolumn{4}{|c|}{ ptimization Trial: Calibration Result for Lo } & \\
\hline \multicolumn{2}{|c|}{$\begin{array}{ll}\text { Start of Trial: } & 01 \text { Jan2004, 00:00 } \\
\text { End of Trial: } & 01 \text { Jan2006, 00:00 } \\
\text { Compute Time: 08Apr2012, 22:30:30 }\end{array}$} & $\begin{array}{l}\text { Basin Model: } \\
\text { Meteorologic Model: } \\
\text { Control Specification }\end{array}$ & $\begin{array}{l}\text { ProjSalinas } \\
\text { Met } 1 \\
\text { ]an2004_De }\end{array}$ & $e c 2005$ \\
\hline \multicolumn{5}{|c|}{ Objective Function at Basin Element "Outlet_Salinas" } \\
\hline \multicolumn{5}{|c|}{$\begin{array}{l}\text { Start of Function : 01 Jan2004, 00:00 } \\
\text { End of Function : } 01 \operatorname{Jan} 2006,00: 00\end{array}$} \\
\hline \multicolumn{5}{|c|}{ Volume Units: (-) IN $\bigcirc \mathrm{AC}-\mathrm{FT}$} \\
\hline Measure & Simulated & Observed & Difference & $\begin{array}{l}\text { Percent } \\
\text { Difference }\end{array}$ \\
\hline Volume (IN) & 17.62 & 17.62 & 0.00 & 0.00 \\
\hline Peak Flow (CFS) & 10898.2 & 9740.0 & 1158.2 & 11.9 \\
\hline Time of Peak & 31Dec2004, 00:00 & 31Dec2004, 00:00 & & \\
\hline Time of Center of Mass & 23Nov2004, 07:33 & 25]an2005, 22:41 & & \\
\hline
\end{tabular}

Figure 9. Results for HEC-HMS calibration for volume.

\begin{tabular}{|c|c|c|c|c|c|c|}
\hline \multicolumn{7}{|c|}{ 四 Optimized Parameter Results for Trial "Calibration Result for Loss" } \\
\hline & & \multicolumn{2}{|c|}{ Project: SalinasRiverSMA } & \multicolumn{3}{|c|}{ Optimization Trial: Calibration Result for Loss } \\
\hline & & \multicolumn{2}{|c|}{$\begin{array}{ll}\text { Start of Trial: } & 01 \operatorname{Jan} 2004,00: 00 \\
\text { End of Trial: } & 01 \operatorname{Jan} 2006,00: 00 \\
\text { Compute Time: 08Apr2012, 22:30:30 }\end{array}$} & \multicolumn{3}{|c|}{$\begin{array}{ll}\text { Basin Model: } & \text { ProjSalinas } \\
\text { Meteorologic Model: } & \text { Met } 1 \\
\text { Control Specifications: Jan2004_Dec2005 }\end{array}$} \\
\hline Element & Parameter & Units & $\begin{array}{l}\text { Initial } \\
\text { Value }\end{array}$ & $\begin{array}{l}\text { Optimized } \\
\text { Value }\end{array}$ & $\begin{array}{c}\text { Objective Function } \\
\text { Sensitivity }\end{array}$ & \\
\hline All Subbasins & Groundwater 1 Capacity Scale Fa... & & 1.00 & 1.0050 & -0.41 & \\
\hline All Subbasins & Groundwater 1 Initial Storage Per... & & 1.00 & 1.5000 & -5.88 & \\
\hline All Subbasins & Groundwater 1 Percolation Rate S... & & 0.60 & 0.60000 & -1.38 & \\
\hline All Subbasins & Groundwater 1 Storage Coefficie... & & 1.0242 & 1.0340 & 20.86 & \\
\hline All Subbasins & Groundwater 2 Capacity Scale Fa... & & 1.0130 & 1.0130 & 0.98 & \\
\hline All Subbasins & Groundwater 2 Percolation Rate S... & & 0.6 & 0.60000 & -0.76 & \\
\hline All Subbasins & Groundwater 2 Initial Storage Per... & & 1.1552 & 1.1552 & -1.24 & \\
\hline All Subbasins & Groundwater 2 Storage Coefficie... & & 0.65687 & 0.66003 & 74.11 & \\
\hline All Subbasins & Soil Infiltration Rate Scale Factor & & 0.29673 & 0.29673 & 1.33 & \\
\hline All Subbasins & Soil Capacity Scale Factor & & 0.90829 & 0.90829 & -2.21 & \\
\hline All Subbasins & Soil Percolation Rate Scale Factor & & 1.3477 & 1.3477 & 32.40 & \\
\hline All Subbasins & Surface Capacity Scale Factor & & 2.2050 & 2.2050 & -10.00 & \\
\hline All Subbasins & Tension Zone Capacity Scale Factor & & 0.98 & 0.98000 & 1.23 & \\
\hline All Subbasins & Canopy Capacity Scale Factor & & 0.95229 & 0.95229 & 4.31 & \\
\hline All Subbasins & Canopy Initial Storage Percentag... & & 1.00 & 1.00000 & 0.00 & \\
\hline All Subbasins & Surface Initial Storage Percentag... & & 1.00 & 1,00000 & 0.00 & \\
\hline
\end{tabular}

Figure 10. Sensitivity results from calibration for volume. 
Calibration for peak flow was performed next to improve peak flow prediction capability of the model, which also produced very good results. The resulting percent difference for the Sum of Absolute Residuals objective function was $-0.16 \%$. In this calibration, the SMA parameters identified by the first calibration attempt were utilized, and the model was calibrated by adjusting the lag times in each of the river reaches. Changing the length of time it takes for runoff to flow through the river reaches alters when flow gets to junctions to combine with flows coming from other reaches. Adjusting lag times to offset the flows could result in a smaller peak flow, instead of multiple flows combining to form a very large peak flow. The sensitivity analysis table shows none of the river reaches were substantially sensitive to the simulated streamflow, even with drastic changes of up to (50\%) adjustment between initial and optimized values. The following figures are outputs from the HEC-HMS calibration for peak flow.

\begin{tabular}{|c|c|c|c|c|}
\hline \multicolumn{4}{|c|}{ Objective Function Results for Trial "Calibration Result for Loss" } & $\square \quad \square$ \\
\hline \multicolumn{5}{|c|}{ Project: SalinasRiverSMA } \\
\hline \multicolumn{2}{|c|}{$\begin{array}{ll}\text { Start of Trial: } & 01 \operatorname{Jan} 2004,00: 00 \\
\text { End of Trial: } & 01 \mathrm{Jan} 2006,00: 00 \\
\text { Compute Time: 09Apr2012, 09:13:50 }\end{array}$} & $\begin{array}{l}\text { Basin Model: } \\
\text { Meteorologic Model: } \\
\text { Control Specifications }\end{array}$ & $\begin{array}{l}\text { ProjSalinas } \\
\text { Met } 1 \\
\text { Jan2004_De }\end{array}$ & ec2005 \\
\hline \multicolumn{5}{|c|}{ Objective Function at Basin Element "Outlet_Salinas" } \\
\hline \multicolumn{5}{|c|}{$\begin{array}{l}\text { Start of Function : } 01 \operatorname{Jan} 2004,00: 00 \\
\text { End of Function : } 01 \operatorname{Jan} 2006,00: 00\end{array}$} \\
\hline \multicolumn{5}{|c|}{ Volume Units: $\odot$ IN $\bigcirc \mathrm{AC}-\mathrm{FT}$} \\
\hline Measure & Simulated & Observed & Difference & $\begin{array}{c}\text { Percent } \\
\text { Difference }\end{array}$ \\
\hline Volume (IN) & 17.59 & 17.62 & -0.03 & -0.16 \\
\hline Peak Flow (CFS) & 9688.9 & 9740.0 & -51.1 & -0.5 \\
\hline Time of Peak & 31Dec2004, 00:00 & 31Dec2004, 00:00 & & \\
\hline Time of Center of Mass & 23Nov2004, 03:59 & 25]an2005, 22:41 & & \\
\hline
\end{tabular}

Figure 11. Objective function for HEC-HMS calibration for peak flow. 


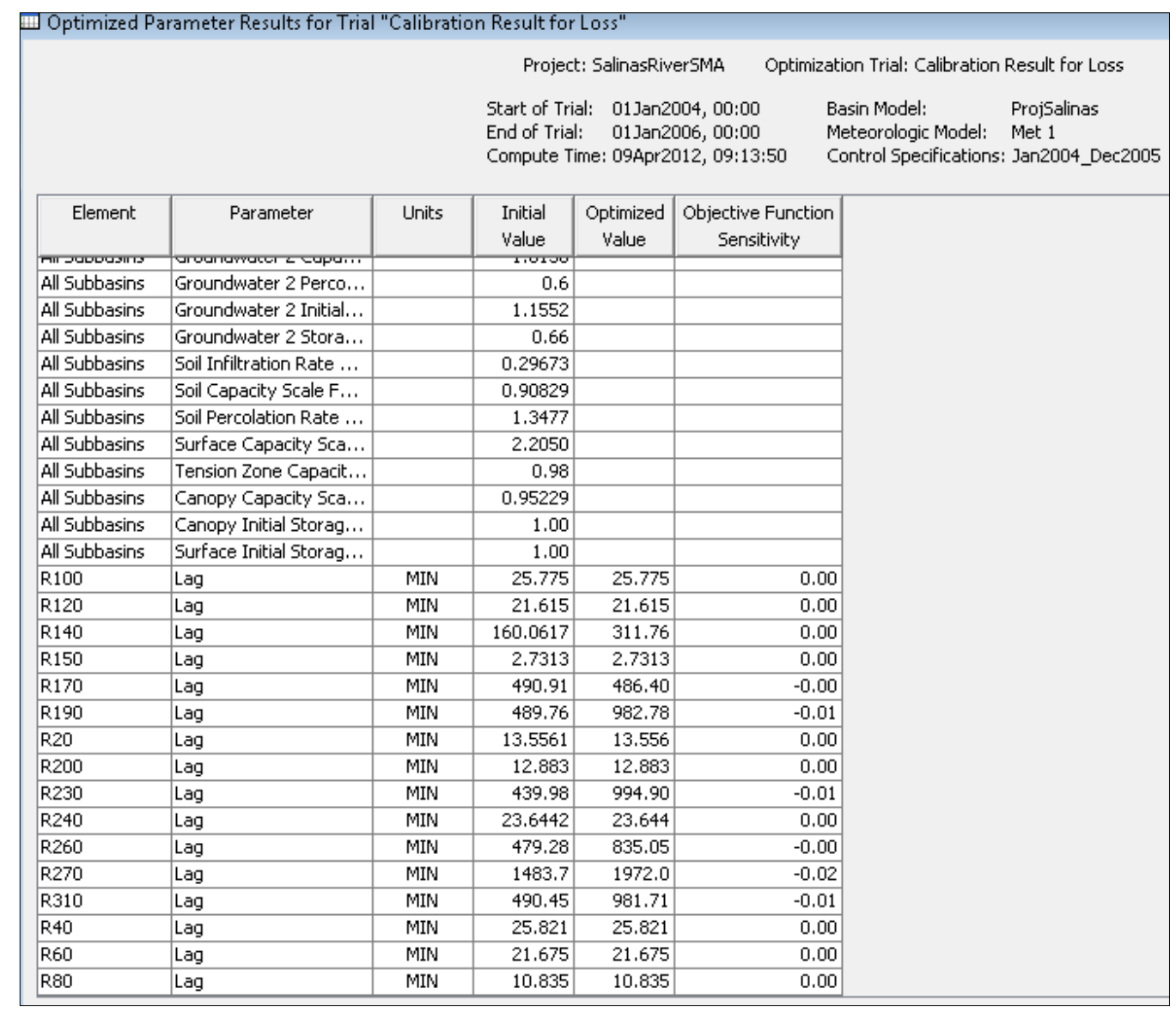

Figure 12. Sensitivity analysis for calibration for peak flow.

After two calibration attempts, the HEC-HMS model reasonably simulated streamflow for the Atascadero Subbasin for the January 2004 to December 2005 calibration period as shown in Figure 13. Prediction accuracy of the model was further examined through the validation process. Validation refers to the process of testing the calibrated model for a period other than the calibration period. If the model can reasonably simulate for this test (validation) period, then the model simulations may be judged satisfactory for the other time period as well. 


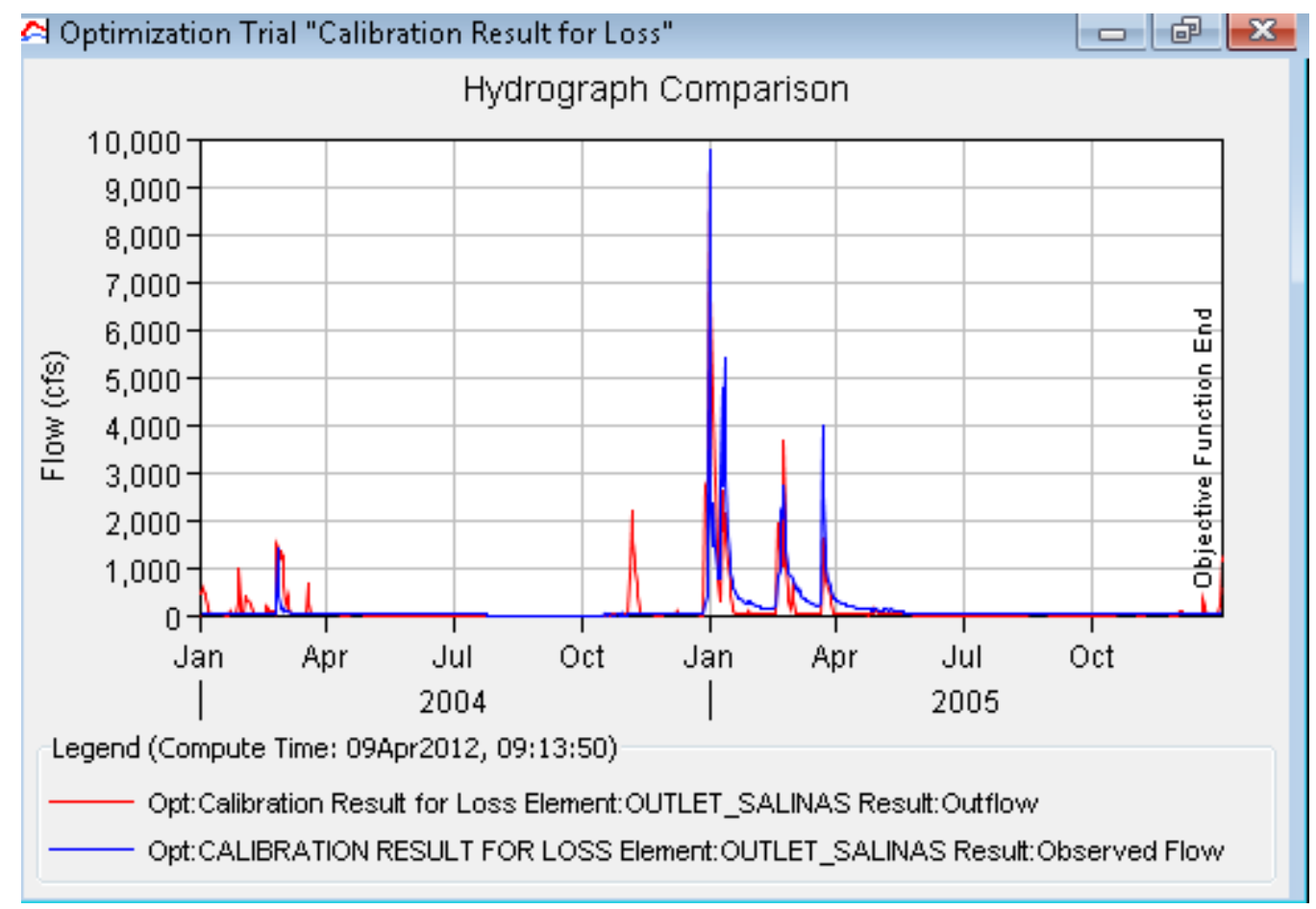

Figure 13. Comparison of observed and simulated streamflow for the calibration period (i.e. for Jan. 2004 to Dec. 2005.)

\section{Validation}

The validation of the HEC-HMS model was completed by simulating the model for the full 10-year period with the optimized SMA parameters and river reach lag times. Figure 14 compares model simulated and observed streamflow for the 10 -year period. The comparison shows that the model simulations are satisfactory. There are some storm events that show significant residuals between simulated and observed but the overall percent difference for the full simulation was $3 \%$. For the purpose of this study, the model parameters identified by the calibration process were considered acceptable to use for the full simulation and based on the validation results, are considered acceptable to use for further analysis. 


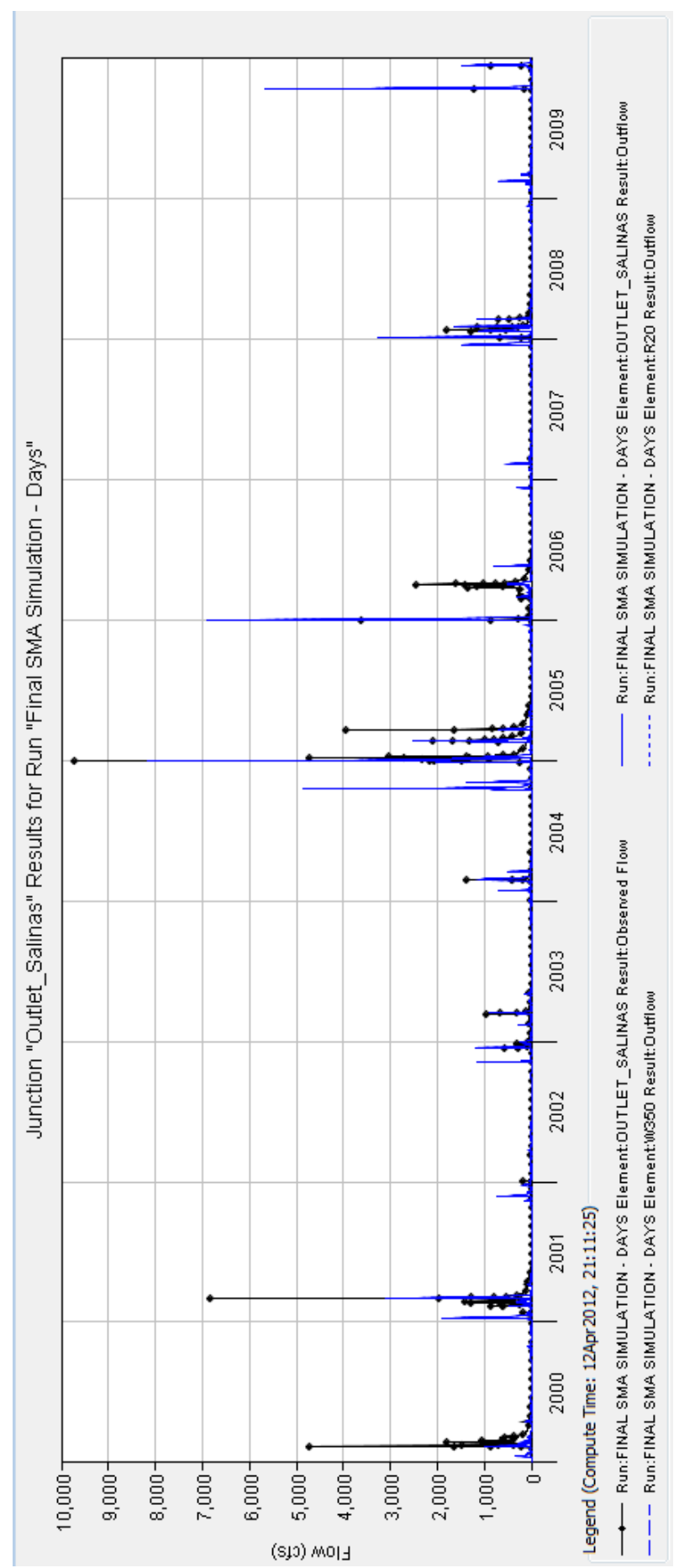

Figure 14. Comparison of observed and simulated streamflow for 10 year period. 


\section{CHAPTER 5: GROUNDWATER MODEL}

\section{Background}

This study used Visual MODFLOW to model the groundwater flow characteristics of the Atascadero Subbasin. Visual MODFLOW is a graphical user interface developed by Schlumberger Water Services to model groundwater flow and contaminant transport (Visual MODFLOW Man., 2004). Visual MODFLOW is a more user friendly version of the MODFLOW software first developed by the USGS in 1981 (Harbaugh 2005). Visual MODFLOW uses the MODFLOW program as its computational engine to simulate groundwater hydraulics as well as contaminant transport processes. Visual MODFLOW is modular, meaning it is broken up into different packages to account for different variations to the groundwater simulation. The different packages allow for a model to be created that can analyze impacts to the groundwater aquifer by streams and rivers, groundwater pumping, and recharge areas. Groundwater flow equations are derived from the following partial differential equation for three-dimensional flow through a porous material (Harbaugh, 2005):

$$
\frac{\partial}{\partial x} K_{x x} \frac{\partial h}{\partial x}+\frac{\partial}{\partial y} K_{y y} \frac{\partial h}{\partial y}+\frac{\partial}{\partial z} K_{z z} \frac{\partial h}{\partial z}+W=S_{s} \frac{\partial h}{\partial t}
$$

where

$\mathrm{K}_{\mathrm{xx}}, \mathrm{K}_{\mathrm{yy}}$, and $\mathrm{K}_{\mathrm{zz}} \quad$ are values of hydraulic conductivity along the $\mathrm{x}, \mathrm{y}, \mathrm{z}$ coordinate axes, which are assumed to be parallel to the major axes of hydraulic conductivity (L/T);

$h \quad$ Is the potentiometric head (L);

W Is a volumetric flux per unit volume representing sources and/or sinks of 
water, with $\mathrm{W}<0.0$ for flow out of the groundwater system, and $\mathrm{W}>0.0$ for flow into the system $\left(\mathrm{T}^{-1}\right)$;

$\mathrm{S}_{\mathrm{s}}$ is the specific storage of the porous material $\left(\mathrm{L}^{-1}\right)$; and is time $(\mathrm{T})$

This equation results in an analytical solution to represent groundwater flow through a heterogeneous, anisotropic medium under non-equilibrium conditions (Harbaugh, 2005). This approach is usually only applied to very simple systems. For complex systems, such as the Atascadero Subbasin system a numerical approach is needed.

The numerical approach used in MODFLOW is finite-difference. The model uses a finite difference scheme over a grid made up of many cells with known dimensions. This method computes following the thermodynamic law of continuity which must be maintained; meaning the rate into and out of the system must equal the rate of change in storage. As the model simulates it computes a mass balance on each cell by taking all the information going into and out of the cell and determines the overall change in storage for the cell. The equation to describe the mass balance of each cell is (Harbaugh, 2005):

$$
\Sigma Q_{i}=S S \frac{\Delta h}{\Delta t} \Delta V
$$

where

$\mathrm{Q}_{\mathrm{i}} \quad$ is a flow rate into the cell $\left(\mathrm{L}^{3} \mathrm{~T}^{-1}\right)$;

SS has been introduced as the notation for specific storage in the finite-difference formulation; its definition is equivalent to that of $\mathrm{S}_{\mathrm{s}}$ in the 3-D groundwater movement equation - that is, SS is the volume of water that can be injected per unit volume of aquifer material per unit change in head $\left(\mathrm{L}^{-1}\right)$;

$\Delta \mathrm{V} \quad$ is the volume of the cell $\left(\mathrm{L}^{3}\right)$; and 
This equation is the driving force of the model and is computed for every cell for each stress period and time step.

Stress periods introduce new data, or stresses, to the model and are generated by the input data to the model. A stress period is the smallest, common time interval of all time-series, or transient, MODFLOW input data (Visual MODFLOW Man., 2004). For example in this model, the pumping, recharge and streamflow data were input on a monthly basis so the stress periods range from $28,29,30$, or 31 days depending on the month. Time steps are increments within a stress period where the model calculates a head solution (Visual MODFLOW Man., 2004). The number of time steps within a stress period are set at 10 by default, but can be manually adjusted to have more or less. Time steps are adjusted by a multiplier, usually greater than one. For this model the number of time steps in a stress period ranged from 20 (beginning of simulation) to 10 , with the time increment adjusted by a 1.2 multiplier. A higher number of time steps and larger multiplier in a stress period makes the actual time step increment smaller at the beginning of a stress period and larger at the end. This helps the model converge when new data stresses are added at a new stress period. The maximum amount of stress periods in the Visual MODFLOW model is 1,000. This limit was restricting when it came to the stream flow data for the Salinas River since daily data for 10 years would require over 3,600 stress periods.

\section{Setup}

Building the Visual MODFLOW model, like HEC-HMS, began in GIS. GIS was used to map the spatial extent of the subbasin, the earthquake fault, well locations, the 
rivers and creeks delineated from the HEC-GeoHMS process, and to build the layer elevations. Most of the spatial data was supplied as a GIS shapefile from either the County of San Luis Obispo or Fugro.

After review of the well logs, the 2002 report by Fugro and Cleath \& Associates, and discussions with Paul Sorensen (a local hydrogeologist), it was determined that there should be three layers built for this model. The three layers and their thicknesses are: Layer 1 spanning the top 100 feet below ground surface and focused on the Salinas River alluvium, Layer 2 covers the next 50 feet of thickness and represents the thin layer of older alluvium and clay separating the river alluvium from the Paso Robles Formation, and Layer 3 covers the remaining model depth, approximately 350 feet thick, and represents the Paso Robles Formation (see Figure 4). The previous Fugro model had four layers; the difference was an added layer to refine the Paso Robles Formation into "upper Paso Robles Formation" and "lower Paso Robles Formation." The Paso Robles Formation is an extremely heterogeneous mixture of clay, sand, and gravel making it very difficult to model (Sorensen, 2010). Due to this extreme heterogeneity, the Paso Robles Formation was left as one layer to gain a general average of the entire layer.

To create the layers, the elevation information was input at the well locations as depth from ground surface. The bottom of Layer 1/top of Layer 2 was set as ground surface minus 100 feet. The bottom of Layer 2/top of Layer 3 was set as ground surface minus 150 feet. The bottom of Layer 3 (the base of permeable soils) was set as ground surface minus 500 feet. GIS was then used to interpolate the surfaces from the wells using the inverse distance method. The inverse distance method estimates an elevation by giving a weight to the known elevation points based upon the distance away from the 
interested location. As the distance of a known point increases, the weight of that point on the interpolation estimation decreases.

After completing spatial data and layer setup in GIS, the information was brought into Visual MODFLOW to create the model domain. Figure 15 shows the model domain of the Atascadero Subbasin. The small circles notate the location of the pumping wells for the City of Paso Robles, Templeton CSD, and AMWC. The Salinas River and its tributary creeks generally flow from south to north to the location of the Paso Robles Stream gage just beyond the boundary of the Subbasin. The cells outside the boundaries of the Atascadero Subbasin were selected to be inactive. The model does not take inactive cells into effect, and they do not alter any of the adjacent active cells. Choosing to make cells inactive allows the Atascadero Subbasin to be treated as hydraulically separate from outside impacts such as the remainder of the Paso Robles Groundwater Basin. The boundary between the Subbasin and main basin is along the Rinconada Fault (eastern boundary). This boundary is not a perfect boundary and leakage does occur. The leakage, however, is minimal compared to losses out of the Subbasin through the Salinas River (Fugro \& Cleath, 2005). For this reason the model was simplified to not allow leakage along the fault line. 


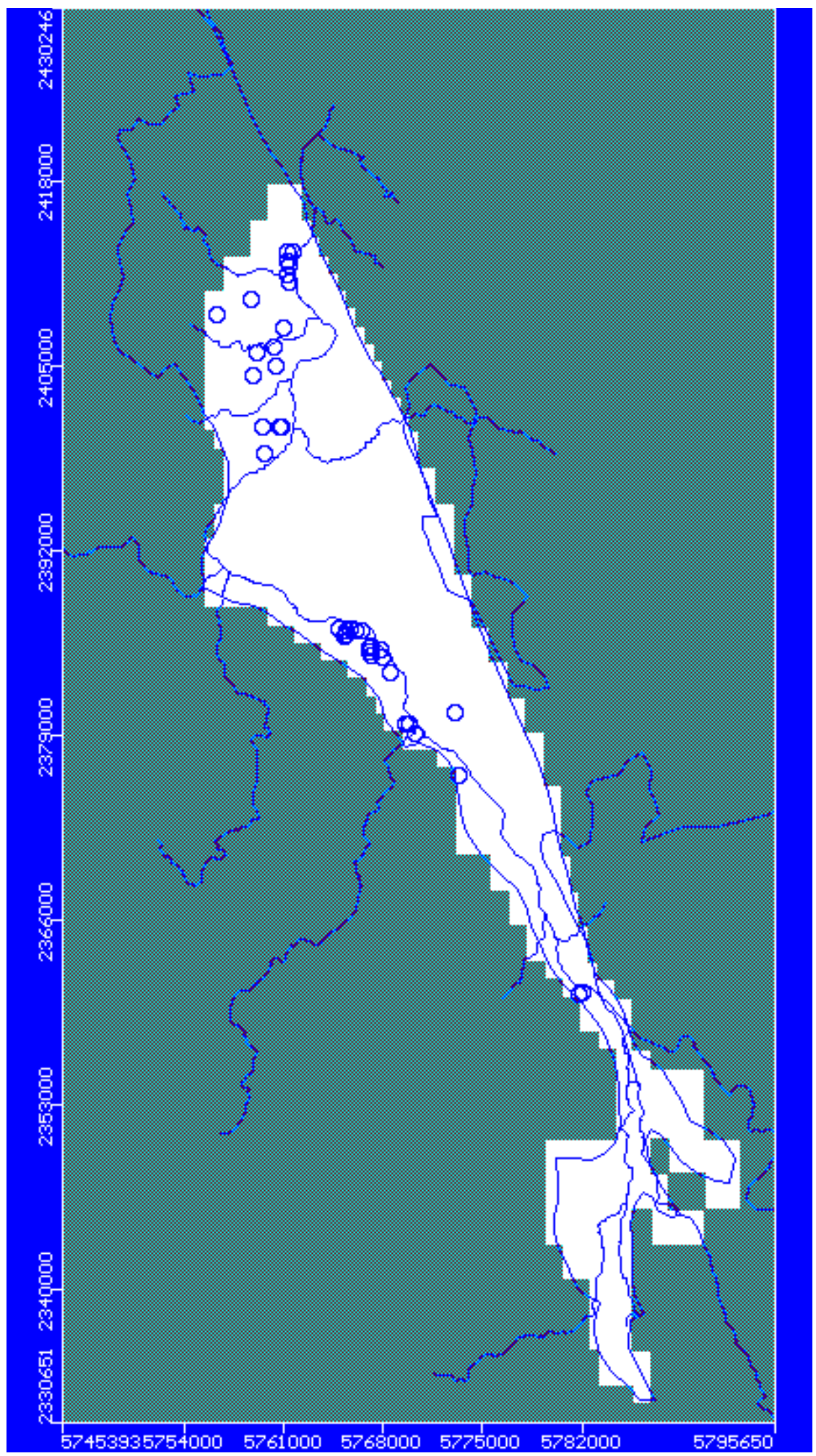

Figure 15. Visual MODFLOW model domain for the Atascadero Subbasin. 
After the model domain was set, soil properties and model stressing data were brought in. Soil properties, hydraulic conductivity, storage coefficient, and total and effective porosity are the required parameters. The initial values for hydraulic conductivity and storage input to the model were from the optimized Fugro model since both that model and the model created for this study are for the same area. The table below summarizes the initial parameters.

Table 1. Initial soil property inputs to the Visual MODFLOW model from Fugro model.

\begin{tabular}{|l|rrcc|}
\hline \multirow{2}{*}{ Soil/Zone } & \multicolumn{5}{|c|}{ Initial Values (Fugro) } \\
\cline { 2 - 5 } & Kx [ft/d] & Kz [ft/d] & Sy & Ss [1/ft] \\
\hline Salinas River Alluvium & 250.000 & 25.000 & 0.200 & - \\
Older Alluvium/Clay 1 & 0.200 & 0.100 & 0.100 & $1.0 \mathrm{E}-05$ \\
Older Alluvium/Clay 2 & 0.010 & 0.001 & 0.100 & $1.0 \mathrm{E}-05$ \\
Paso Robles Formation & 8.000 & 1.000 & 0.100 & $1.0 \mathrm{E}-05$ \\
\hline
\end{tabular}

In the Fugro model there is a slight change in the clay hydraulic conductivity near Atascadero. South of Atascadero is a less conductive layer and is noted with a "2" in the table above. North of Atascadero the clay layer becomes more conductive as is noted with a "1." This may be due to more of the older alluvium present that is not as consolidated. However, previous reports indicate the clay in Layer 2 surrounding Templeton increases in thickness and retards vertical flow percolation (Fugro \& Cleath, 2002). Soil porosity for the different soils was estimated from recommended ranges based on soil type. The alluvium effective porosity is equal to the specific yield, $20 \%$, and the total porosity was estimated to be $30 \%$. The total porosity for the clay was set higher than the alluvium at $35 \%$, but the effective porosity was set at $5 \%$. The Paso Robles Formation was similar to the clay layer, with total porosity of $35 \%$, but a higher effective porosity of $10 \%$. 
Next, the pumping well data were input at the locations shown above. The data required for this input were the screen interval elevations and pumping rates at their various time intervals. The pumping rates were input in the model in gallons per day (GPD). Visual MODFLOW can model both extraction and recovery wells, it depends on the sign convention used. Extraction wells, which include all wells in this model, are input as negative numbers to show water is taken out of the groundwater (Visual MODFLOW Man., 2004). Following input of the pumping wells, the observation well data were brought into the model.

Most observation data were located at a pumping well. This created problems for observations when the well was on and pumping. A limitation to Visual MODFLOW is that the model cannot model drawdown at a pumping well; instead it calculates drawdown for the entire cell based on the initial head observation minus calculated head (Visual MODFLOW Man., 2004). To get past this problem, observation data were only used when a well was not pumping. This reduced the number of useable observation readings, but allowed for model convergence and better calibration. Another issue was that all of the observation data available were in the northern half of the model domain. Water levels and changes could be analyzed for the region surrounding the three cities involved, which are near the outlet downstream on the Salinas River, but the lack of data in the upstream portion of the Subbasin means that the water elevation in this area could not be verified. The following figure shows the location of the available observation locations. 


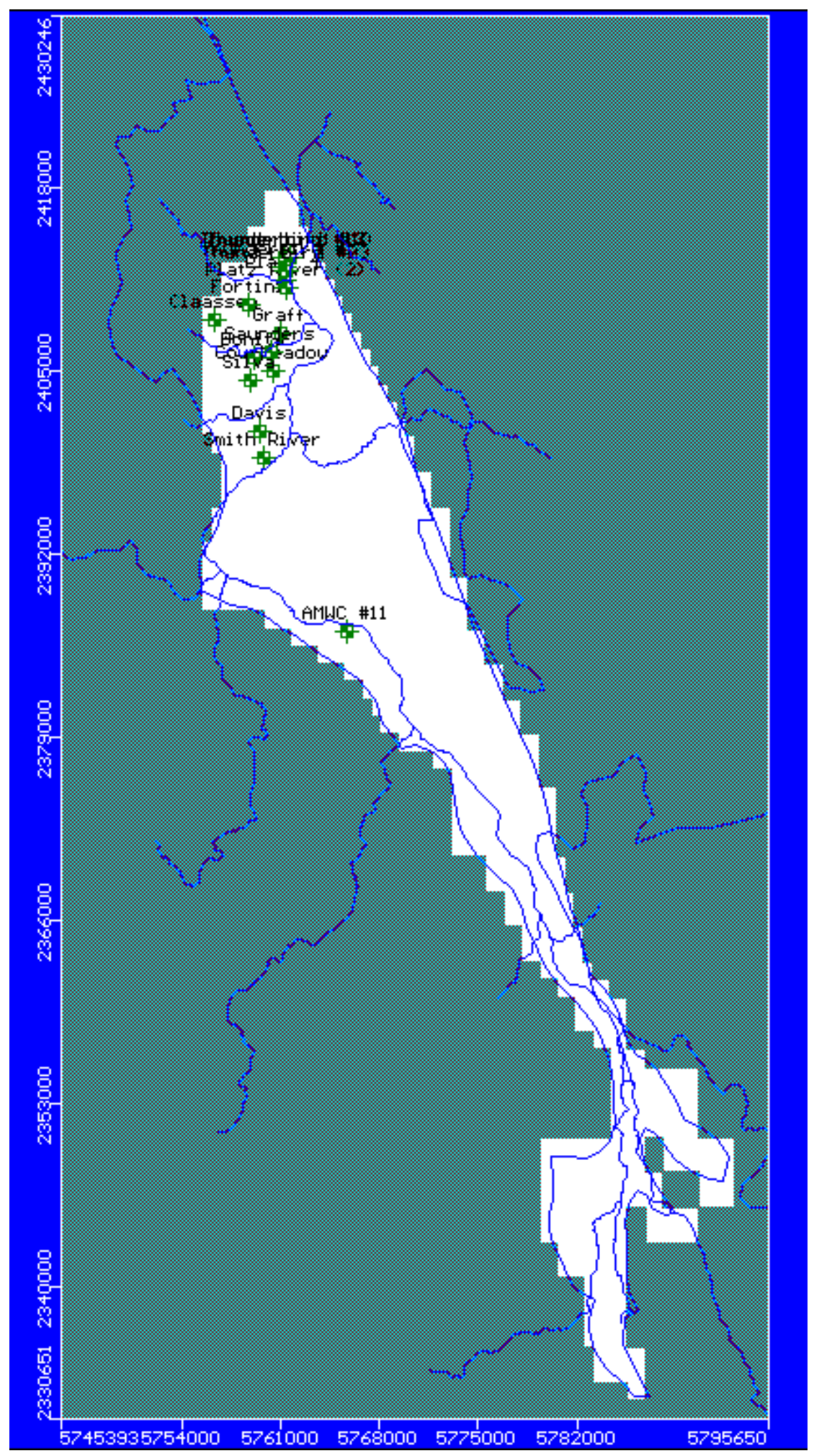

Figure 16. Observation Well Locations for the Visual MODFLOW analysis. 
Recharge is also crucial data that needs to be specified. The Recharge package in Visual MODFLOW was used to input the recharge data generated from the HEC-HMS model. Rates varied depending on the amount of rainfall that fell during the month. The wet months (December through March) generally saw the highest recharge rates. The table below shows an example of the monthly recharge variability during 2004.

Table 2. Monthly Recharge to groundwater for the year 2004 (HEC-HMS output)

\begin{tabular}{|c|c|c|c|}
\hline \multirow{2}{*}{ Month } & \multicolumn{3}{|c|}{ Recharge by Region (in) } \\
\cline { 2 - 4 } & Atascadero & Templeton & Paso Robles \\
\hline January & 0.84 & 0.54 & 2.85 \\
February & 3.08 & 3.29 & 1.86 \\
March & 0.12 & 0.00 & 2.85 \\
April & 0.00 & 0.00 & 0.39 \\
May & 0.00 & 0.00 & 0.00 \\
June & 0.00 & 0.00 & 0.00 \\
July & 0.00 & 0.00 & 0.00 \\
August & 0.00 & 0.00 & 0.00 \\
September & 0.00 & 0.00 & 0.00 \\
October & 3.03 & 2.02 & 2.02 \\
November & 1.06 & 1.65 & 1.65 \\
December & 4.06 & 4.23 & 4.23 \\
\hline
\end{tabular}

Finally, streamflow and stage (flow depth) data for the Salinas River needs to be specified. Originally the River Package in Visual MODFLOW was to be used to simulate the river interaction with the groundwater, but the river package was very rigid in the way that flow data were provided and did not allow for tributary flows to be defined to the river at the confluences along the River length. The Stream Package was more flexible with input of flows for different segments and also allows for flows from tributary creeks to be added. The river and tributary creeks were drawn in from upstream to downstream, which is required for the model to understand direction of flow (Visual MODFLOW Man, 2004). 
The stream package requires several pieces of information to run a river simulation: the start and stop times of a flow at a specified rate (cubic feet per day for the stream package), channel width, stage height elevation, the top and bottom of streambed elevation, and the vertical hydraulic conductivity of the streambed soil. Daily flow rate data were generated in the HEC-HMS model. The daily data were averaged for each month and put into the monthly stress periods of Visual MODFLOW in order to not exceed the maximum amount of stress periods. This average decreases the peak flow that the groundwater model will see during its simulation, but is necessary to allow the model to run.

The channel width for all Salinas River segments was selected to be 50 feet and the channel width for all tributary creeks was selected to be 10 feet. The stream channels change widths as they meander through the subbasin. The Salinas River channel was based upon dimensions at the Paso Robles gage station and aerial mapping. A single channel width was chosen for the river and stream for simplicity to determine stage height. Channel widths were kept on the smaller end of the spectrum for both the tributary creeks and the Salinas River. The width of the Salinas River varies from approximately 40 feet to over 200 feet while the tributary creek widths range from about six feet to approximately 50 feet. The reason for choosing smaller widths was to allow for more variation in height with flow and to account for the low flow channel since several months near the end of the summer period have little to no flow. Stage height was calculated using a simple rectangular cross section, since that is the shape Visual MODFLOW treats rivers and streams. The longitudinal slope and streambed top elevation were determined at each segment by the elevation data from USGS. The 
streambed thickness was arbitrarily picked as four feet for all segments, making all streambed bottom elevations four feet less than the streambed top elevation. The vertical conductivity of the streambed was set the same as the vertical conductivity of the Salinas River alluvium of 25 feet per day. The following figure shows the river and creeks in the Subbasin. There are several larger creeks in the area, the Paso Robles Creek, Graves Creek, and Atascadero Creek, that do not have flow gages on them. The flow from these creeks and other tributary inflows is simulated using the HEC-HMS model. 


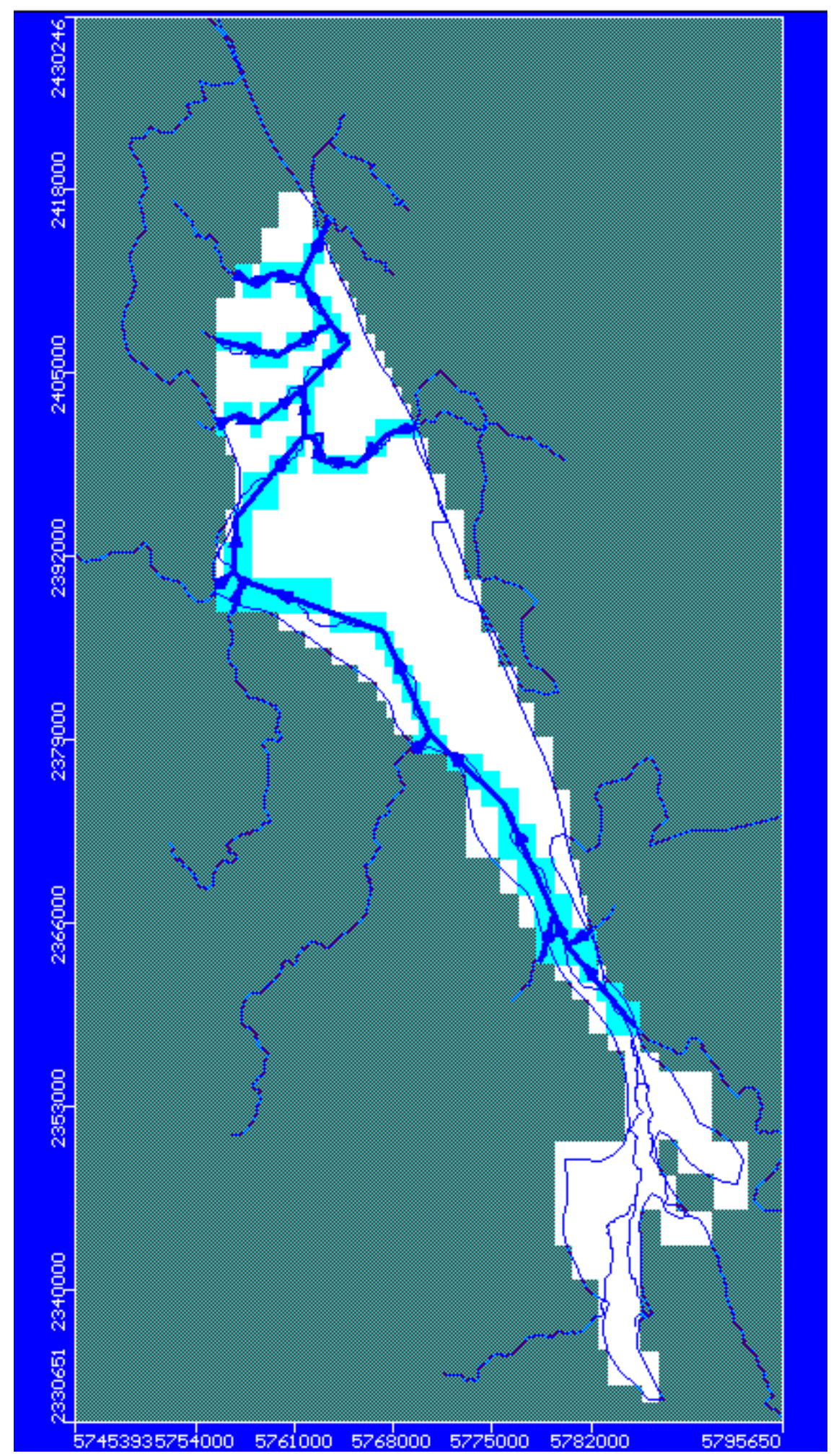

Figure 17. Stream package input in Visual MODFLOW model. 
The stream package calculates the conductance along a linear gradient from the up and downstream points for each reach (cell) the stream flows through. Conductance is a numerical parameter representing the resistance to flow between the surface water body and the groundwater caused by the specified riverbed. The equation that the model uses to calculate conductance in each cell is (Visual MODFLOW Man, 2004):

$$
C=\frac{K \times L \times W}{M}
$$

where

C is the conductance through the streambed $\left(\mathrm{L}^{2} \mathrm{~T}^{-1}\right)$

$\mathrm{K} \quad$ is the vertical hydraulic conductivity of the streambed material $\left(\mathrm{LT}^{-1}\right)$

$\mathrm{L} \quad$ is the length of the reach through a cell (L)

W is the stream channel width (L)

M is the thickness of the streambed (L)

This conductance calculation plays a key role in determining the interaction between the surface water and groundwater and which direction the water moves. If the conductance value is large there is less resistance between the two water bodies and they will act more like a single water body during the model simulation.

\section{Calibration}

A second groundwater model was built for the calibration process. The model was chosen to be calibrated using the 2002 year as a sample year, so the second model is identical but only contains data for the 2002 calendar year. This year was chosen because it had the most available non-pumping observation data in an effort to try and match the actual groundwater elevations. Calibration was performed using a built-in software package within Visual MODFLOW known as PEST, which stands for Parameter 
ESTimation. PEST allows the modeler to optimize parameters much faster than a manual method. PEST allows the model to be calibrated based upon hydraulic conductivities, storage coefficients, and recharge (WinPEST Man., 1999). For this model the hydraulic conductivities and storage coefficients for each layer were considered for calibration, resulting in 13 calibrable parameters. The goal of the PEST calibration is to generate a factor, known as a Marquardt Lambda, that when applied to the matrix of initial parameter values will reduce the error function of the model. The error function is known as the "phi value" in PEST. PEST tries to reduce this phi value by increasing or decreasing the Marquardt Lambda. By minimizing the phi value the residual differences between the simulated and observed data are reduced (WinPEST Man., 1999). The PEST objective function is based upon a sum of squared deviations. The phi equation in PEST is:

$$
\Phi=c-X b^{t} c-X b
$$

where

$\Phi \quad$ is the resulting phi objective function

c is the set of observed data

$\mathrm{X}$ is the matrix of disturbances that change the parameters

b is a vector of the system parameters

$\mathrm{t}$ Indicates the matrix transpose operation

For the 2002 model calibration some assumptions were made regarding the hydraulic conductivities. First, the horizontal hydraulic conductivity was assumed to be equal in the $\mathrm{x}$ and $\mathrm{y}$ directions. These parameters were linked in PEST so that for each parameter, the original $\mathrm{K}_{\mathrm{x}}$ and $\mathrm{K}_{\mathrm{y}}$ values would be adjusted by the same amount. This is 
a typical assumption when dealing with hydraulic conductivity. Usually horizontal conductivities are fairly similar in the $\mathrm{x}$ and $\mathrm{y}$ directions and are combined to one horizontal conductivity value, $\mathrm{K}_{\mathrm{h}}$. Another assumption made was that the horizontal conductivity is 10 times larger than the vertical conductivity. The 10:1 ratio is typical between horizontal and vertical conductivities, and this relationship was previously used in the Fugro groundwater model (Fugro \& Cleath, 2005). This was built into PEST in a previous information tab using this logarithmic formula:

$$
\log K_{x}-\log K_{z}=1
$$

This relationship was given a weight of $75 \%$ to allow PEST an option to adjust to a parameter that was slightly different than the 10:1 assumption. This was allowed since the soil properties are very heterogeneous and changes are not uniform.

The calibration of the 2002 year data resulted in a very good fit. The correlation and residuals can be seen in the following figures. Overall the correlation for the entire one year period was 0.973 with a Normalized Root Mean Squared percentage of $6.219 \%$. The residuals ranged from -10.5 to 21.1 feet with an average residual being -0.084 feet. 


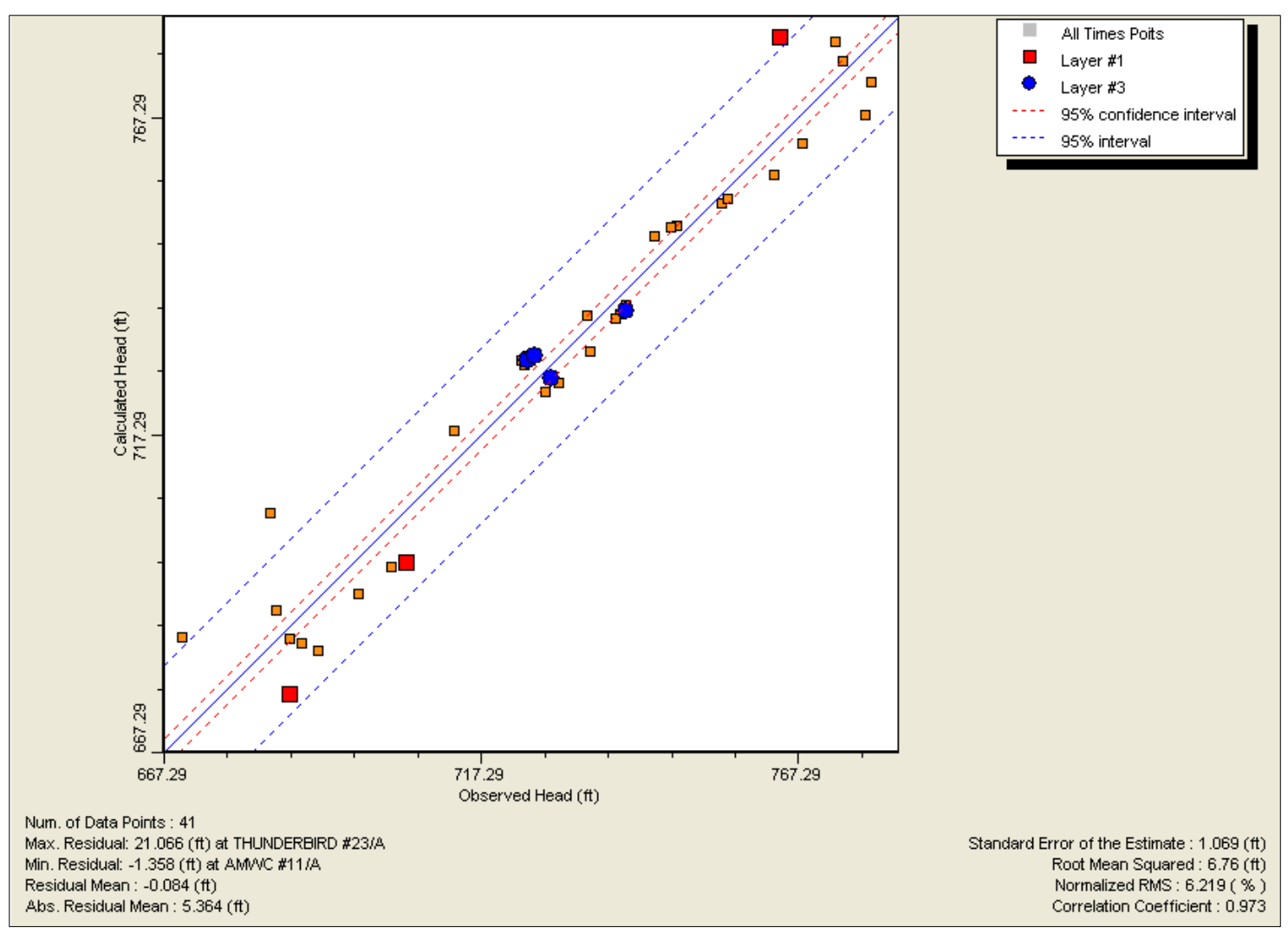

Figure 18. Calculated vs. Observed heads for MODFLOW calibration year 2002. 


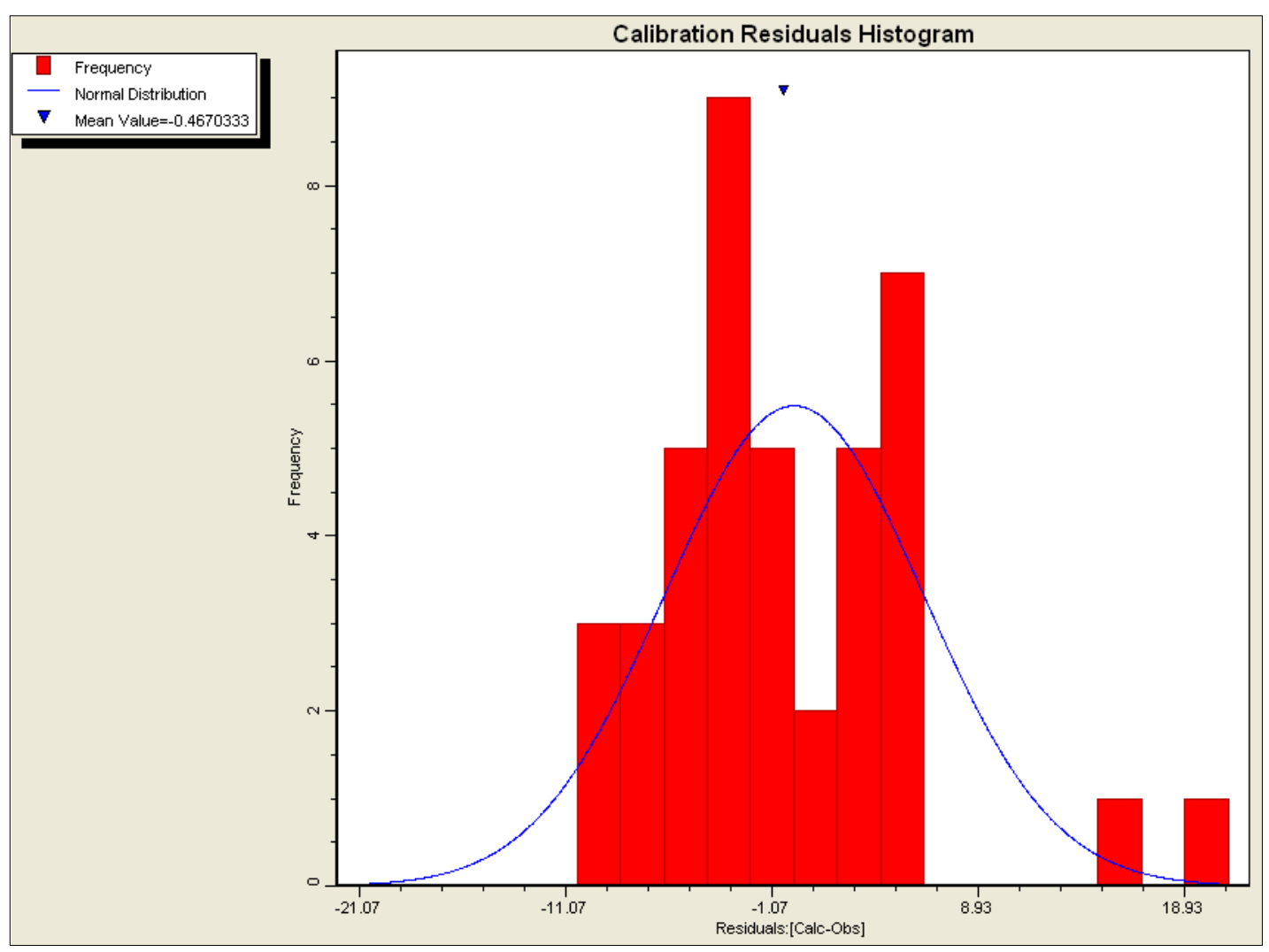

Figure 19. Residual distribution for year 2002 model calibration.

The optimized parameters from the 2002 model were entered into the 10 -year model for validation. The table below shows a comparison of the original parameters and how they changed after calibration. There was a significant increase in the horizontal conductivity for the older alluvium/clay 1 soil (soil north of Atascadero). This could indicate there is more influence by the older alluvium than the clay. The horizontal conductivity of the Paso Robles Formation increased significantly indicating water in this layer is more likely to flow laterally across the Subbasin rather than up and out. Overall the storage coefficients were reduced. 
Table 3. Comparison of conductivity and storage parameters by soil.

\begin{tabular}{|l|rrr|r|rrr|r|}
\hline & \multicolumn{4}{|c|}{ Initial Values (Fugro) } & \multicolumn{4}{c|}{ PEST Calibrated Values } \\
\cline { 2 - 9 } \multicolumn{1}{|c}{ Soil/Zone } & Kx [ft/d] & Kz [ft/d] & \multicolumn{1}{c|}{ Sy } & Ss [1/ft] & Kx [ft/d] & Kz [ft/d] & \multicolumn{1}{c|}{ Sy } & Ss [1/ft] \\
\hline Salinas River Alluvium & 250.000 & 25.000 & 0.200 & - & 208.935 & 31.880 & 0.0553 & - \\
Older Alluvium/Clay 1 & 0.200 & 0.100 & 0.100 & $1.0 \mathrm{E}-05$ & 10.000 & 3.9242 & 0.00001 & $1.9 \mathrm{E}-08$ \\
Older Alluvium/Clay 2 & 0.010 & 0.001 & 0.100 & $1.0 \mathrm{E}-05$ & 0.55688 & 0.15072 & 0.00001 & $1.9 \mathrm{E}-08$ \\
Paso Robles Formation & 8.000 & 1.000 & 0.100 & $1.0 \mathrm{E}-05$ & 15.002 & 0.0279 & 0.05637 & $1.0 \mathrm{E}-08$ \\
\hline
\end{tabular}

\section{Validation}

The 10-year model was simulated after input of the 2002 optimized parameters. The resulting fit and residuals were not as good as the calibration fit but was still deemed acceptable. There appeared to be some data from 3 wells drilled into the third layer that did not match well. These three wells are located near Templeton, and are also near other deep wells that appeared to fit with the observed values. It is unknown at this point whether the observation data for these wells are questionable or if there is a localized change in the soil properties around these three wells.

The Normalized Root Mean Squared percentage is $18.368 \%$ with all the data, which is shown in Figure 21 below. Without the three bad fitting wells the percentage drops down to approximately $12 \%$. These wells also affected the correlation. The total correlation for the 10 -year simulation was 0.715 , but jumps up near 0.9 when these wells are taken out. The residuals ranged from -64.4 to 128.8 feet but the majority of the data (75\%) was in the range of 0 to 38.6 feet and averaged at 21.249 feet. The positive residual indicates the simulated head values are slightly higher than the observed data. 


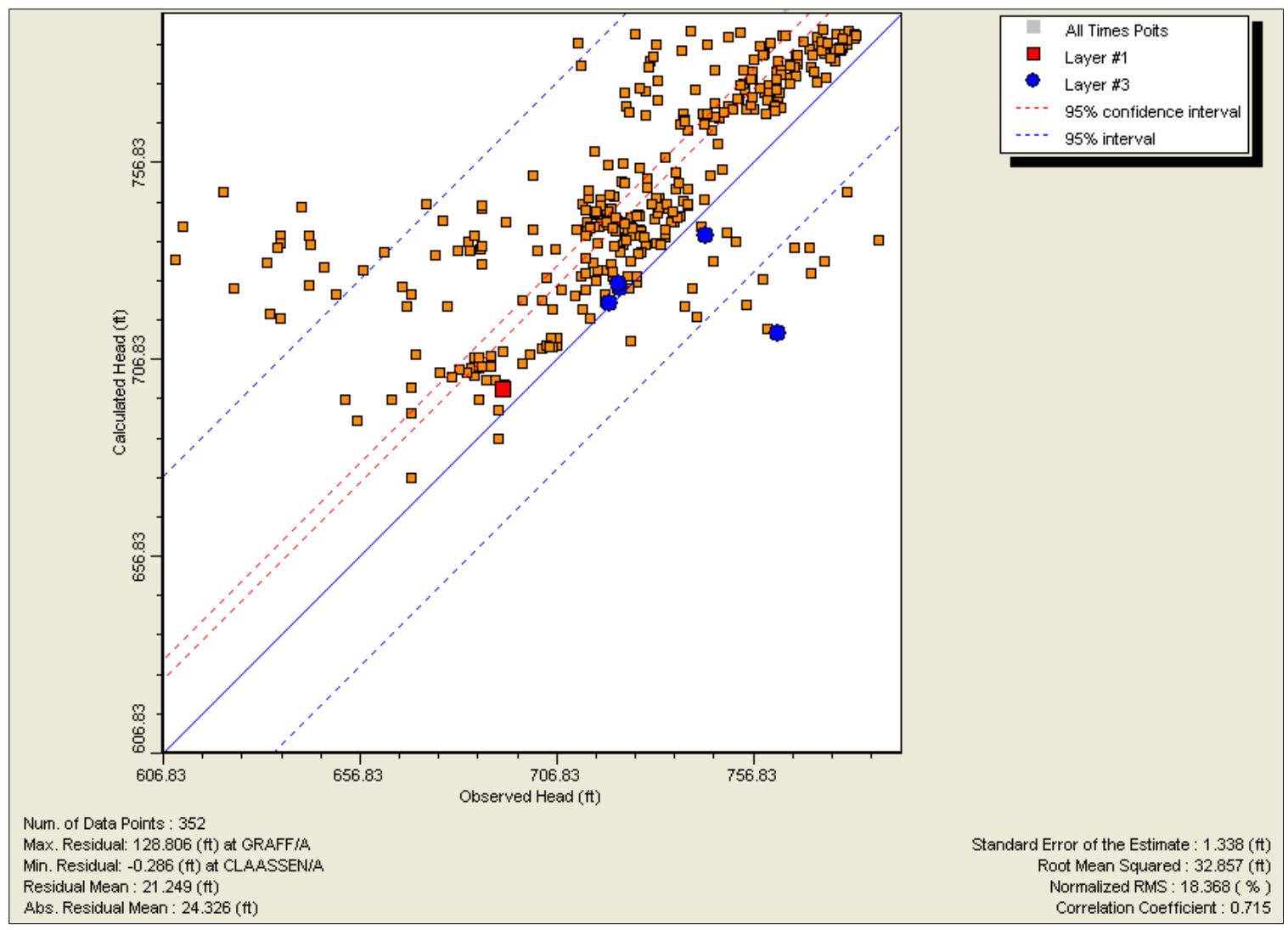

Figure 20. Calculated versus Observed Heads for full optimized model. 


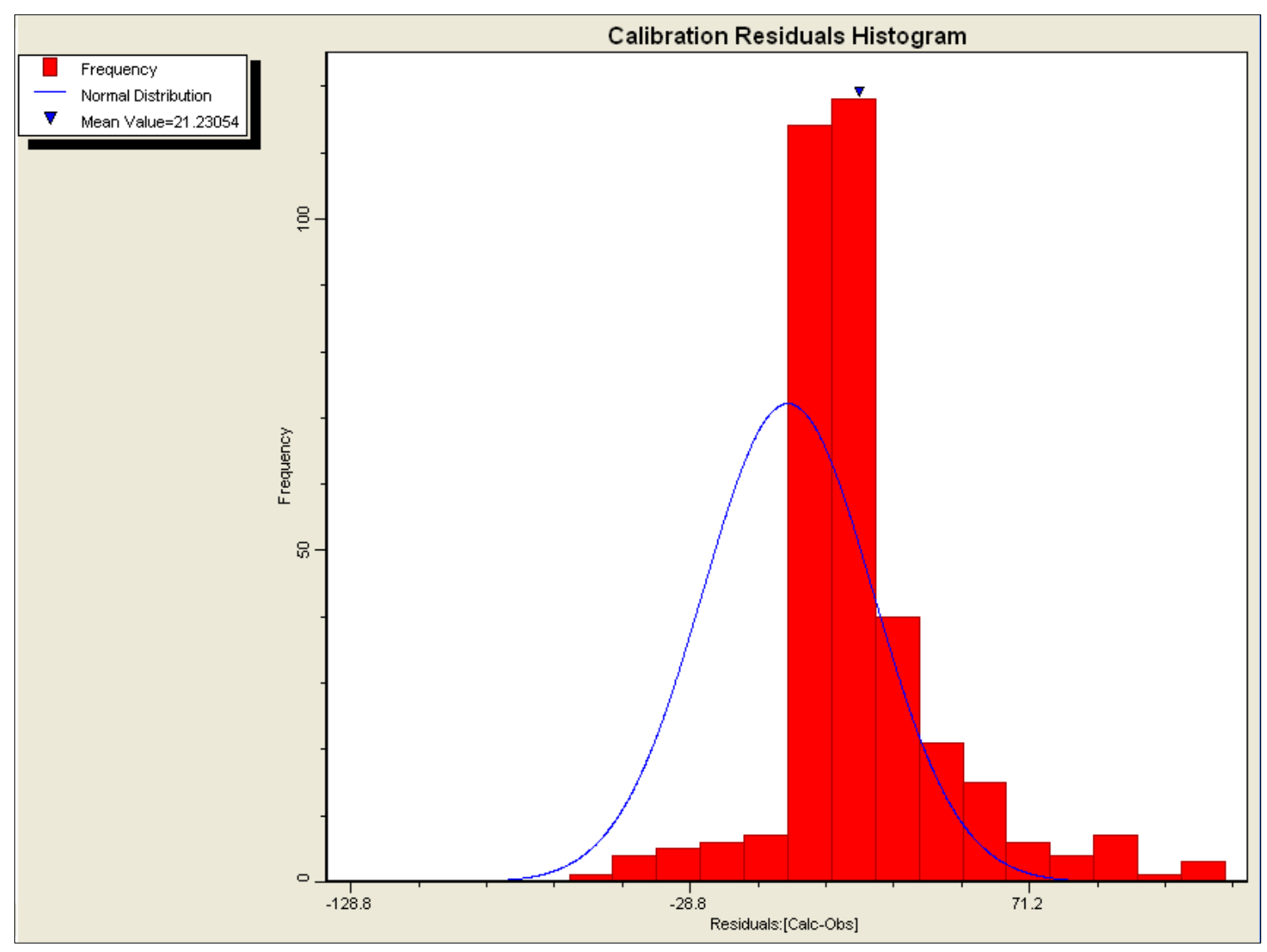

Figure 21. Residual distribution for full optimized model. 


\section{CHAPTER 6: RESULTS \& DISCUSSION}

This chapter discusses the results from the surface water and groundwater analyses after both models were calibrated and validated.

\section{Evaluation of HEC-HMS Results}

The HEC-HMS model simulation was successful as the simulated results fit the observed data very well. Peak and low flows occur at approximately the same time for both simulated and observed. The peak flow occurs during the wet winter from 2004 to 2005, while the low flows occur almost every dry period as there is no flow in the Salinas River for much of the summer months. The SMA method was able to generate valuable information regarding percolation to groundwater. The amount percolated to groundwater was dependent on the type of water year (wet or dry). As expected, wet years produced more percolation to groundwater while dry years percolated less. The interesting result was the quantity of water percolated to groundwater. The average rainfall for the area ranges from 15 to 17 inches per year. The average amount of water percolated to groundwater was just above 10 inches per year. The majority of the rainfall in this region is delivered to the groundwater. This is most likely due to the significant amount of agricultural, range, and natural areas in the sub-watershed and to the presence amount of hills and valleys that trap water rather than create runoff like impervious surfaces do. Given these results the groundwater aquifer receives a significant percentage of the precipitation each year through percolation. 


\section{Evaluation of Visual MODFLOW Results}

Analysis of the Visual MODFLOW model focused on reviewing the model at time steps believed to be at the high and low groundwater elevations during a year. April is believed to be the month with the highest groundwater elevations and October the month with the lowest groundwater elevations. The October to April time period is characterized by having low or no pumping from wells and significant amounts of recharge as these are wet (winter) months where most precipitation occurs over the area. April to October is characterized by high levels of pumping and negligible recharge as this is dry (summer) months where there is little to no precipitation and water demand is high. Selecting a date at the end of each period results in the largest extremes for each year. Both Layer 1 (alluvium) and Layer 3 (Paso Robles Formation) were analyzed in this way to determine how they each changed over time and their relationship to each other.

The first analysis was to evaluate the flow direction in localized areas with groundwater pumping near the Salinas River. The areas chosen were near each of the three cities in the area: Atascadero, Templeton, and Paso Robles. In the area chosen for Atascadero there are six wells. Three of the wells (AMWC 4, 16, and 19) are shallow pumping wells and the other three are deep pumping wells (AMWC 7, 9, 10). The area chosen for Templeton had four pumping wells. Three of these wells were deep pumping wells (Silva, Cow-Meadow, and Davis) and one was a shallow pumping well (Creekside River). The region analyzed for Paso Robles had six wells. Five wells were shallow pumping wells (Platz River and the four Thunderbird wells) and one deep well (Platz 4). 
The objective of this first analysis was to determine if the Salinas River was flowing to the aquifer or if water in the aquifer was flowing to the Salinas River. Year 2000 was first analyzed to determine the direction of flow at the start of the model. Analysis then moved to year 2005, which was the wettest year of the study period, to assess how increased recharge changed direction of groundwater flow. Year 2009 was then analyzed since it was near the end of a 3 year dry period during the study period. Analyzing this period allowed for assessment on direction of flow with increased pumping and minimal flow. The following figures show a time series from April to October for each of the three years analyzed for both Layer 1 and Layer 3. Larger arrows signify a larger magnitude of flow. Layer 1 saw larger flows than Layer 3, which was expected given the hydraulic conductivities of the two layers. Red arrows notate flow is leaving the layer and blue arrows show flow entering the layer.

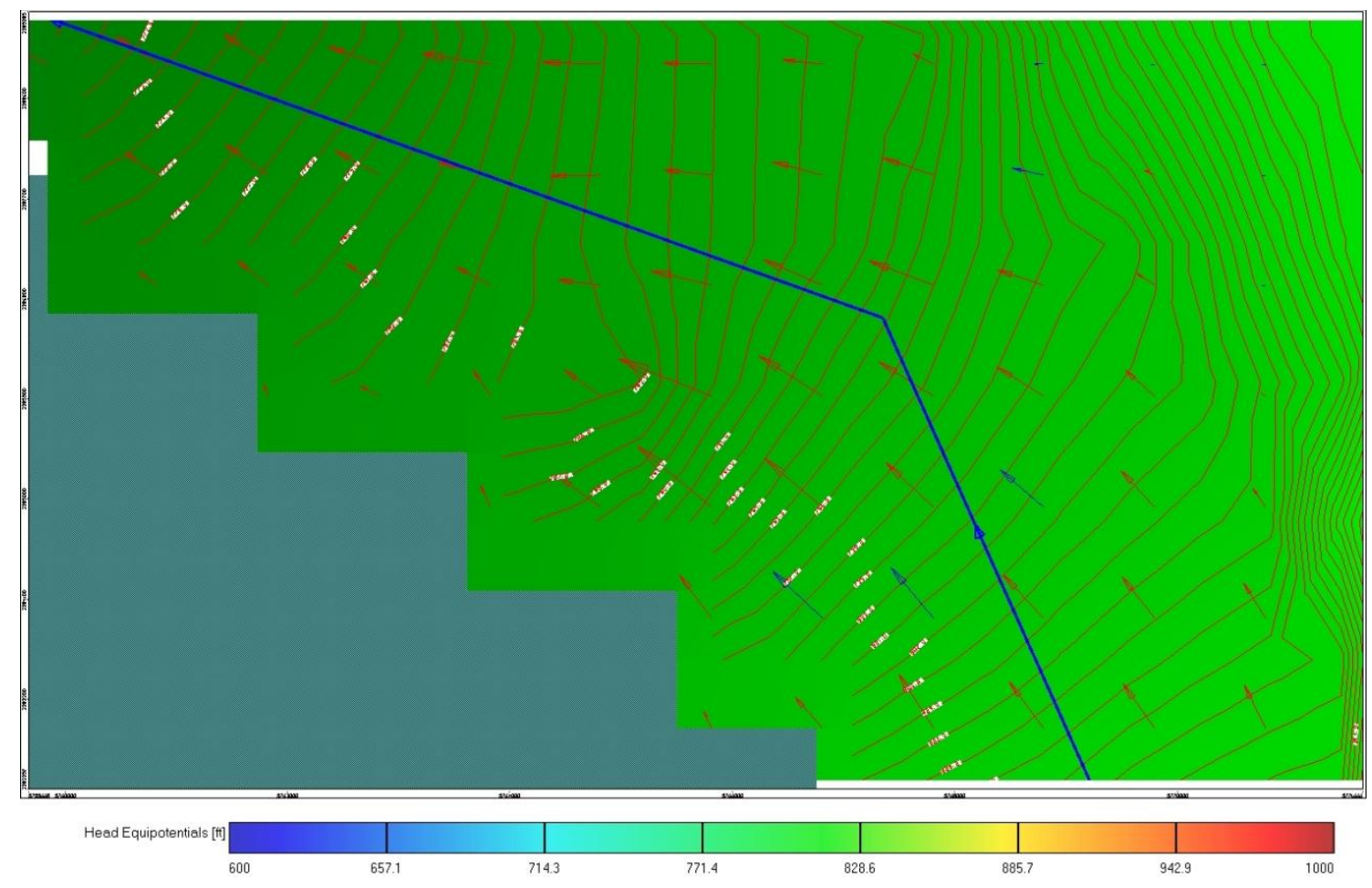

Figure 22. Head contours and flow direction in Layer 1 in Atascadero in April 2000 (Day 91) 


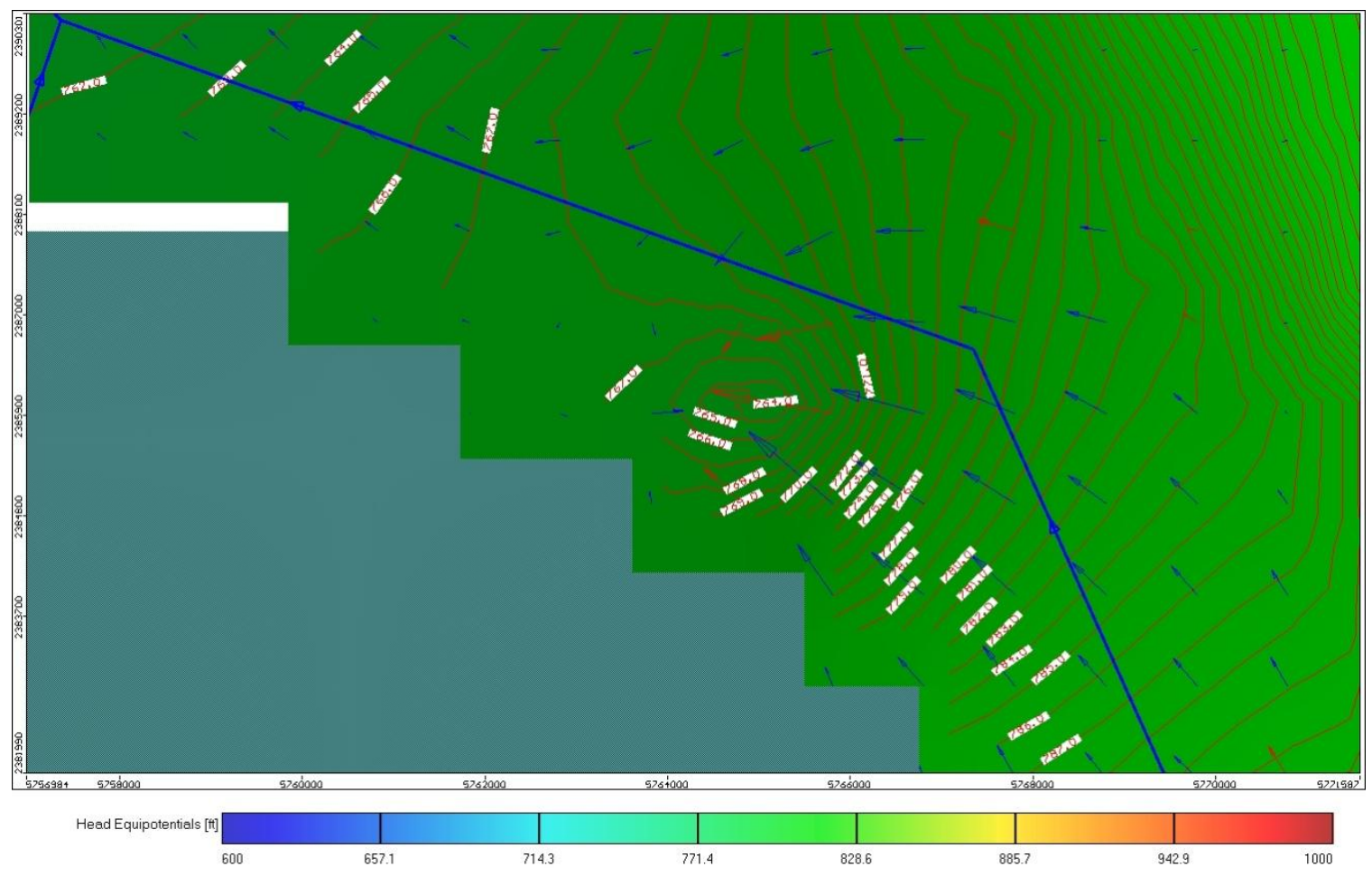

Figure 23. Head contours and flow direction in Layer 1 in Atascadero in October 2000 (Day 273)

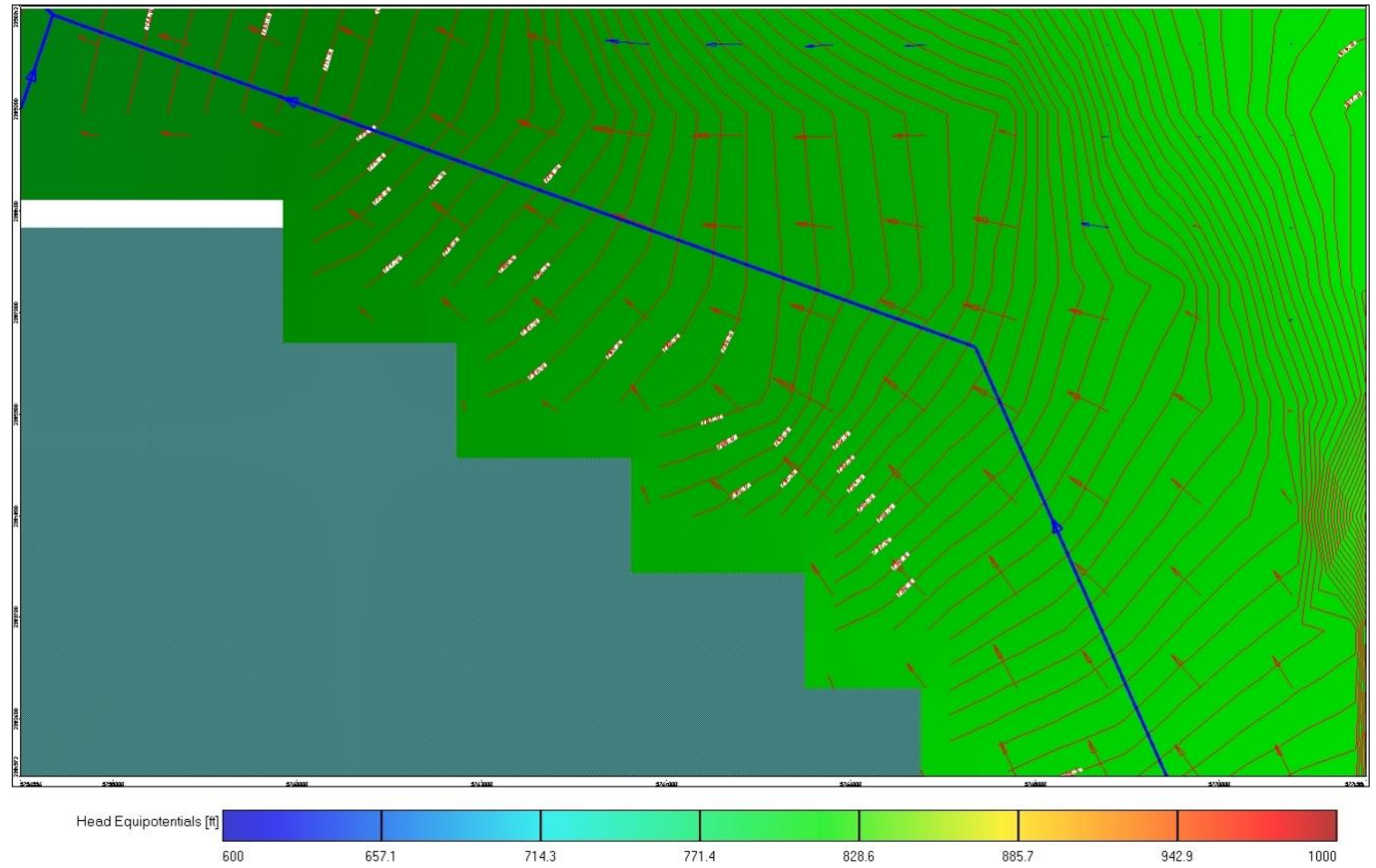

Figure 24. Head contours and flow direction in Layer 1 in Atascadero in April 2005 (Day 1917) 


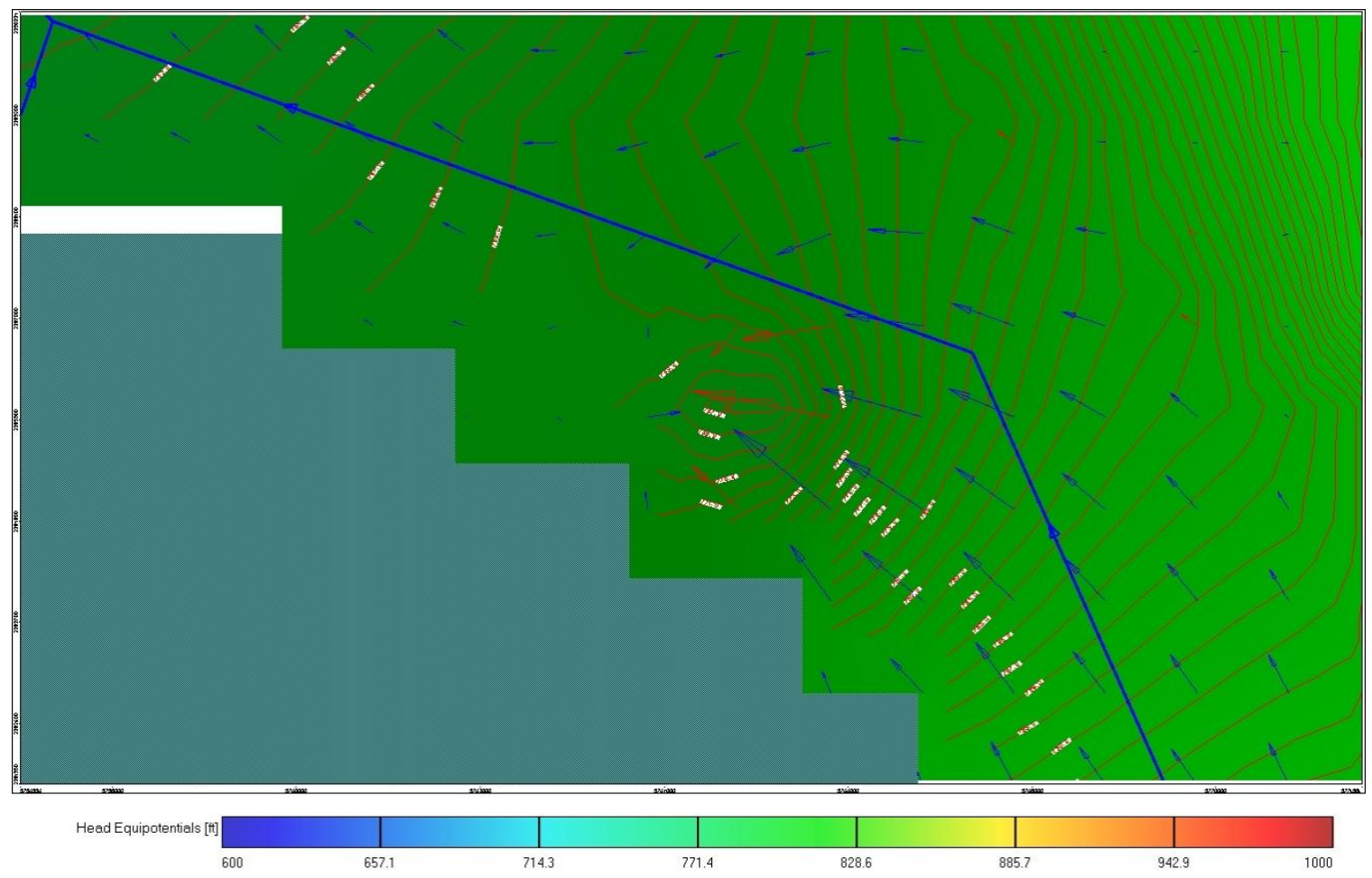

Figure 25. Head contours and flow direction in Layer 1 in Atascadero in October 2005 (Day 2100)

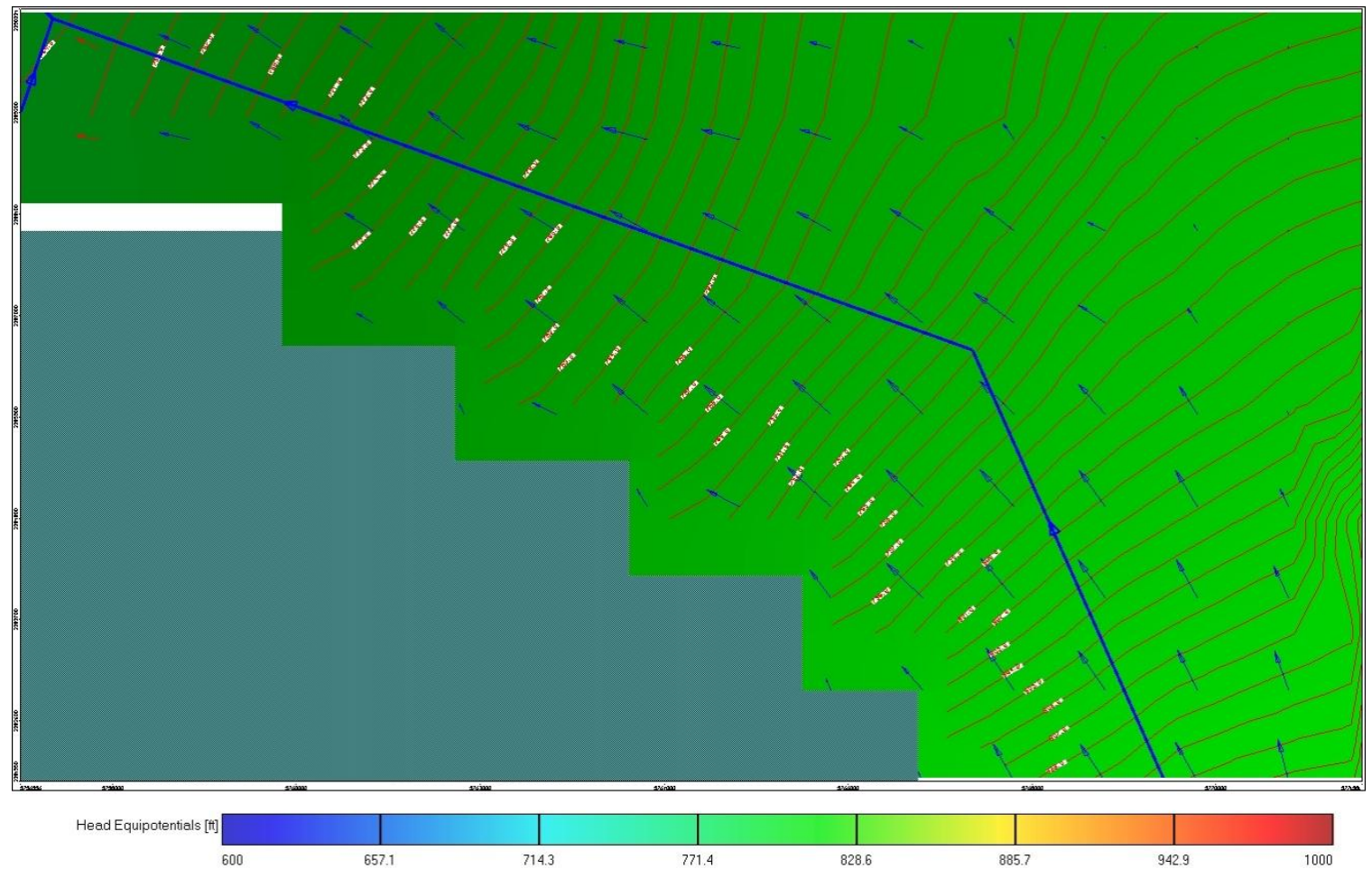

Figure 26. Head contours and flow direction in Layer 1 in Atascadero in April 2009 (Day 3378) 


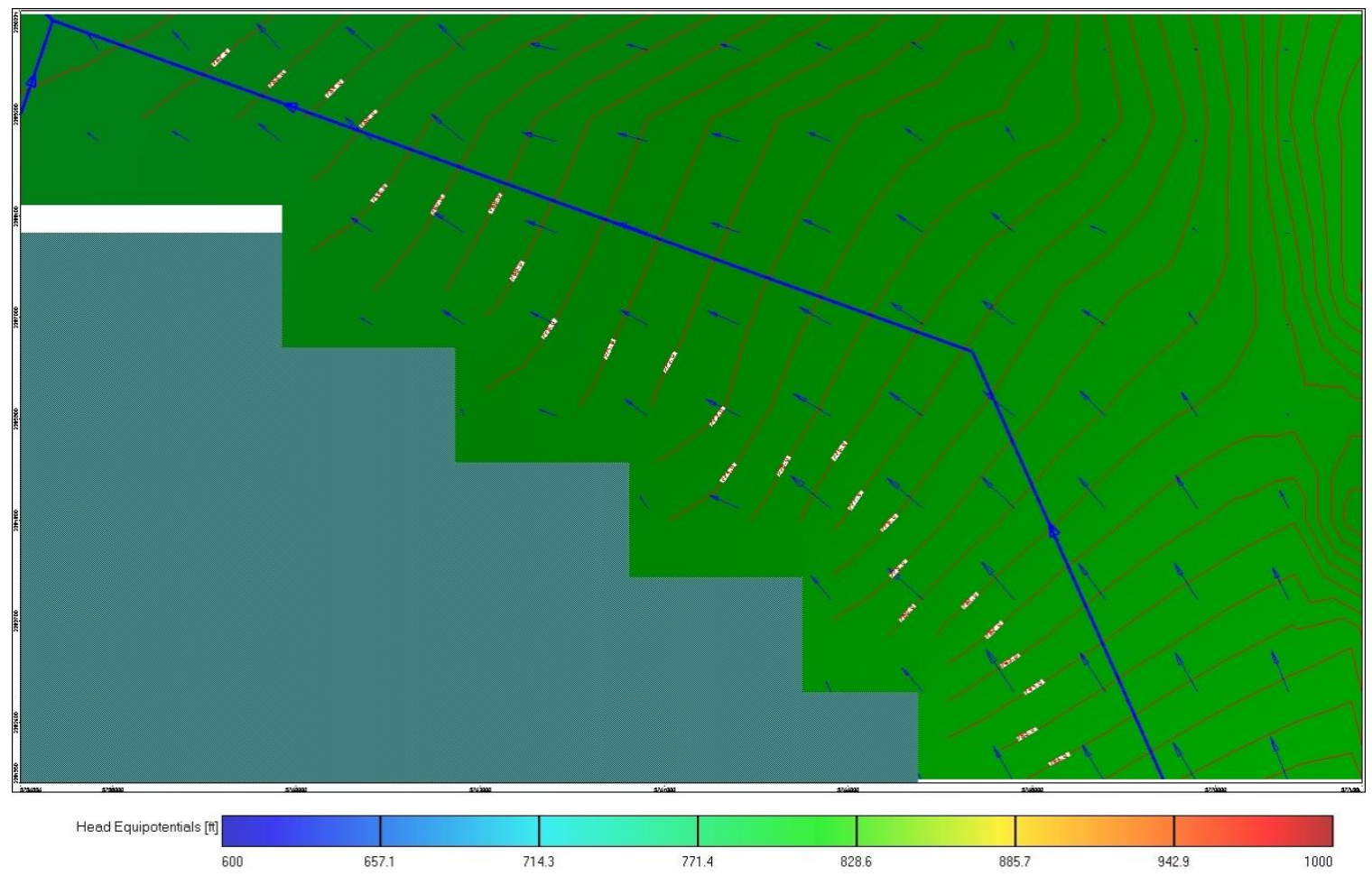

Figure 27. Head contours and flow direction in Layer 1 in Atascadero in October 2009 (Day 3561)

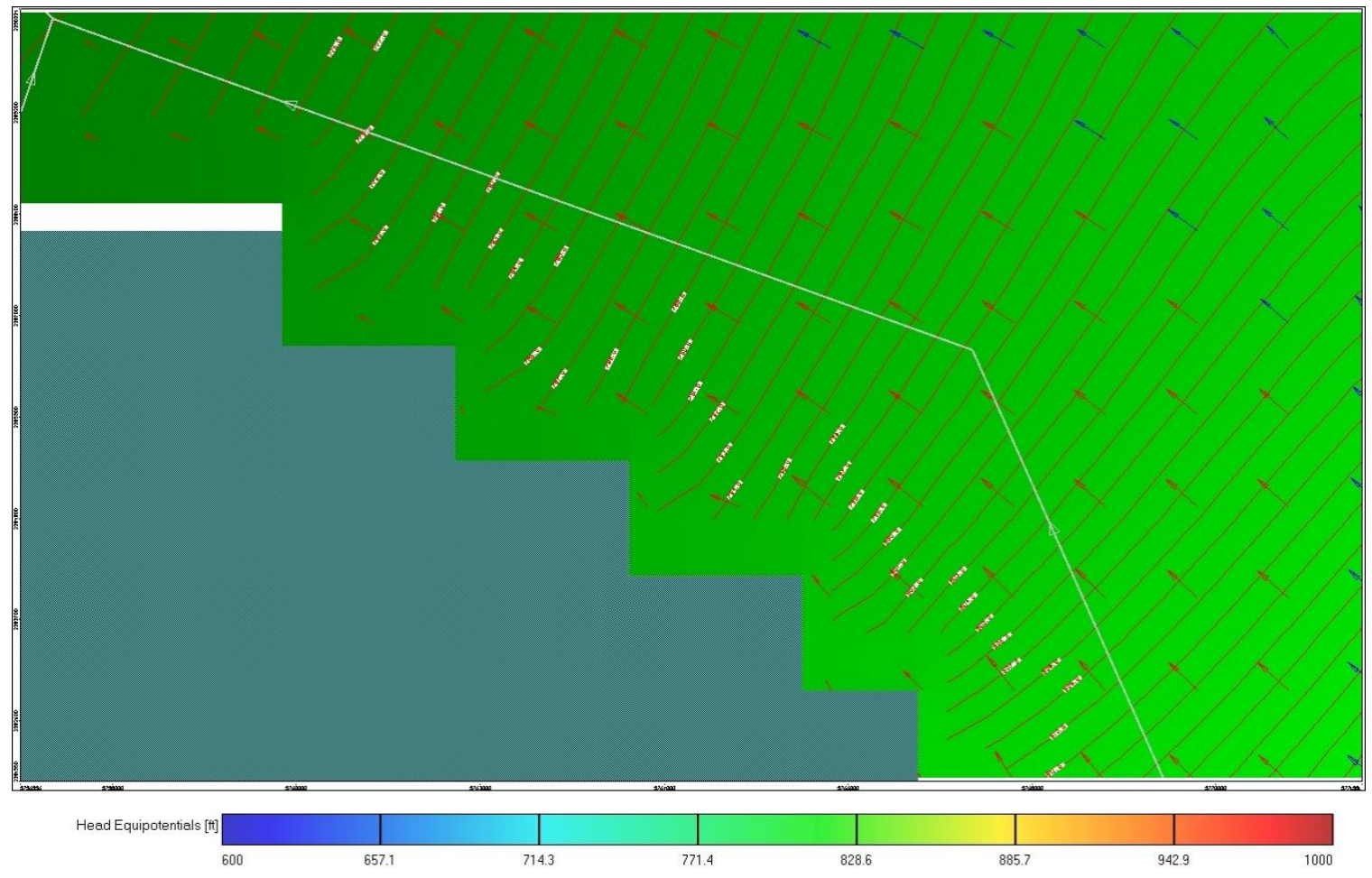

Figure 28. Head contours and flow direction in Layer 3 in Atascadero in April 2000 (Day 90) 


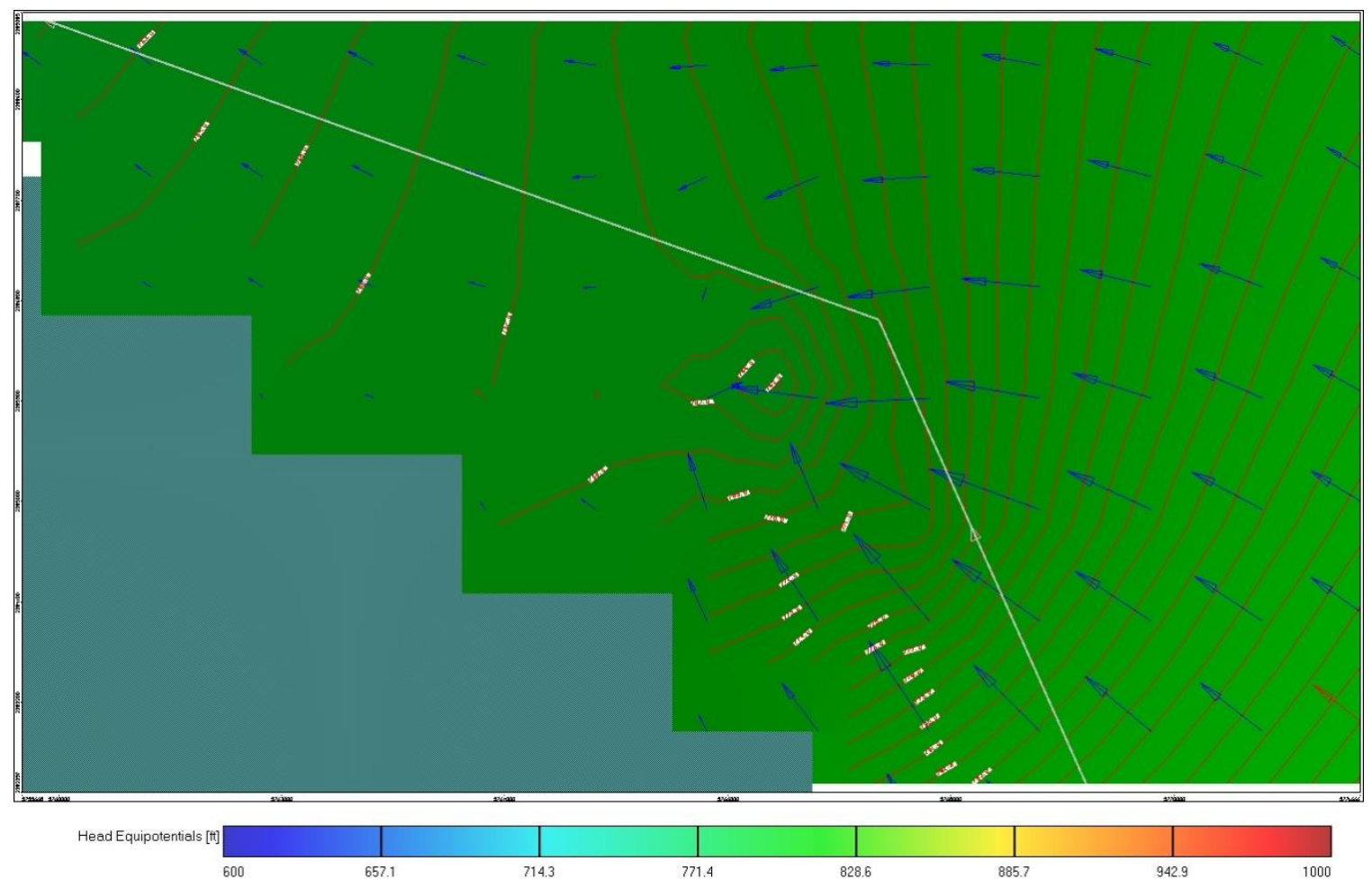

Figure 29. Head contours and flow direction in Layer 3 in Atascadero in October 2000 (Day 273)

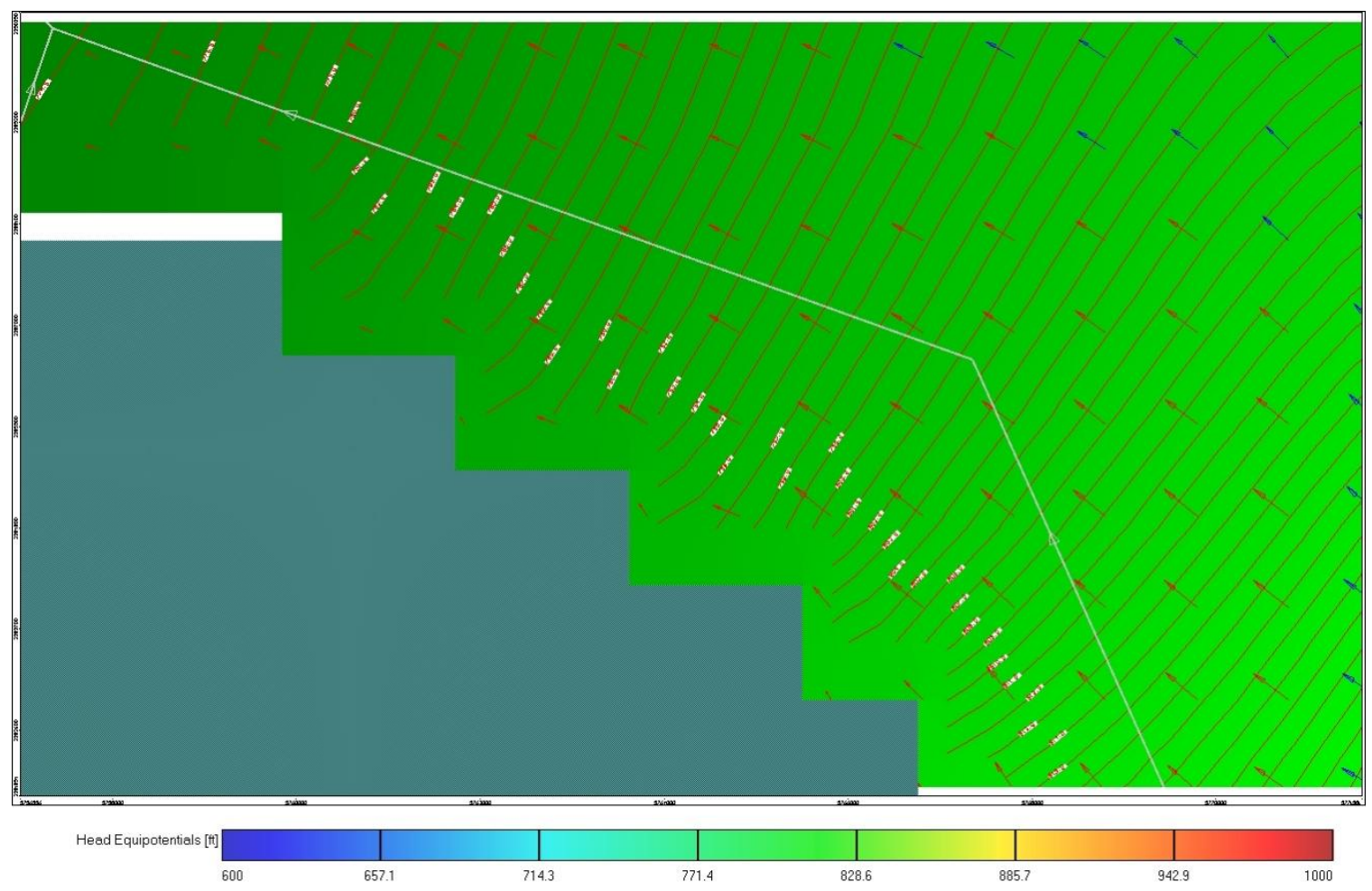

Figure 30. Head contours and flow direction in Layer 3 in Atascadero in April 2005 (Day 1917) 


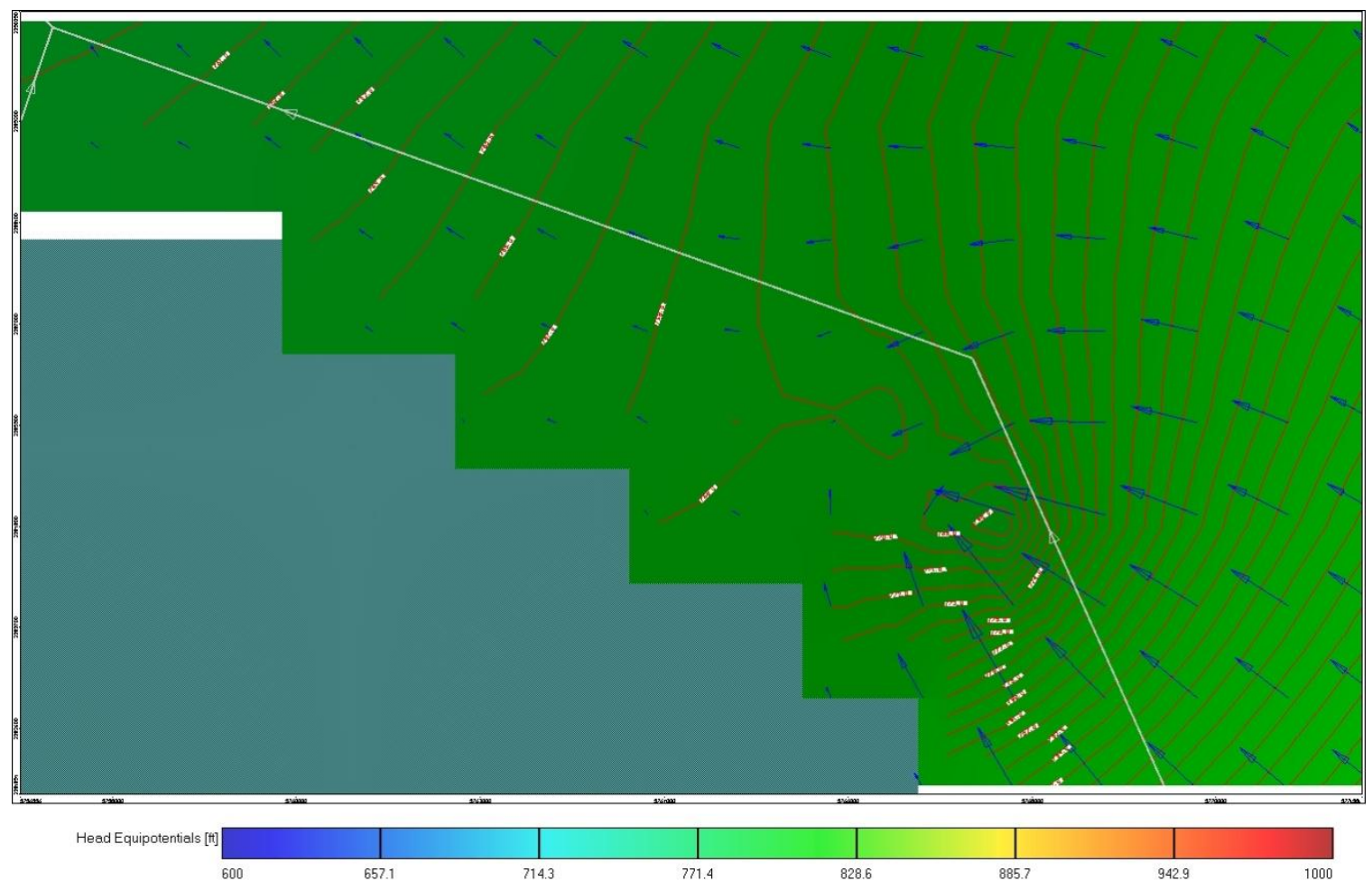

Figure 31. Head contours and flow direction in Layer 3 in Atascadero in October 2005 (Day 2100)

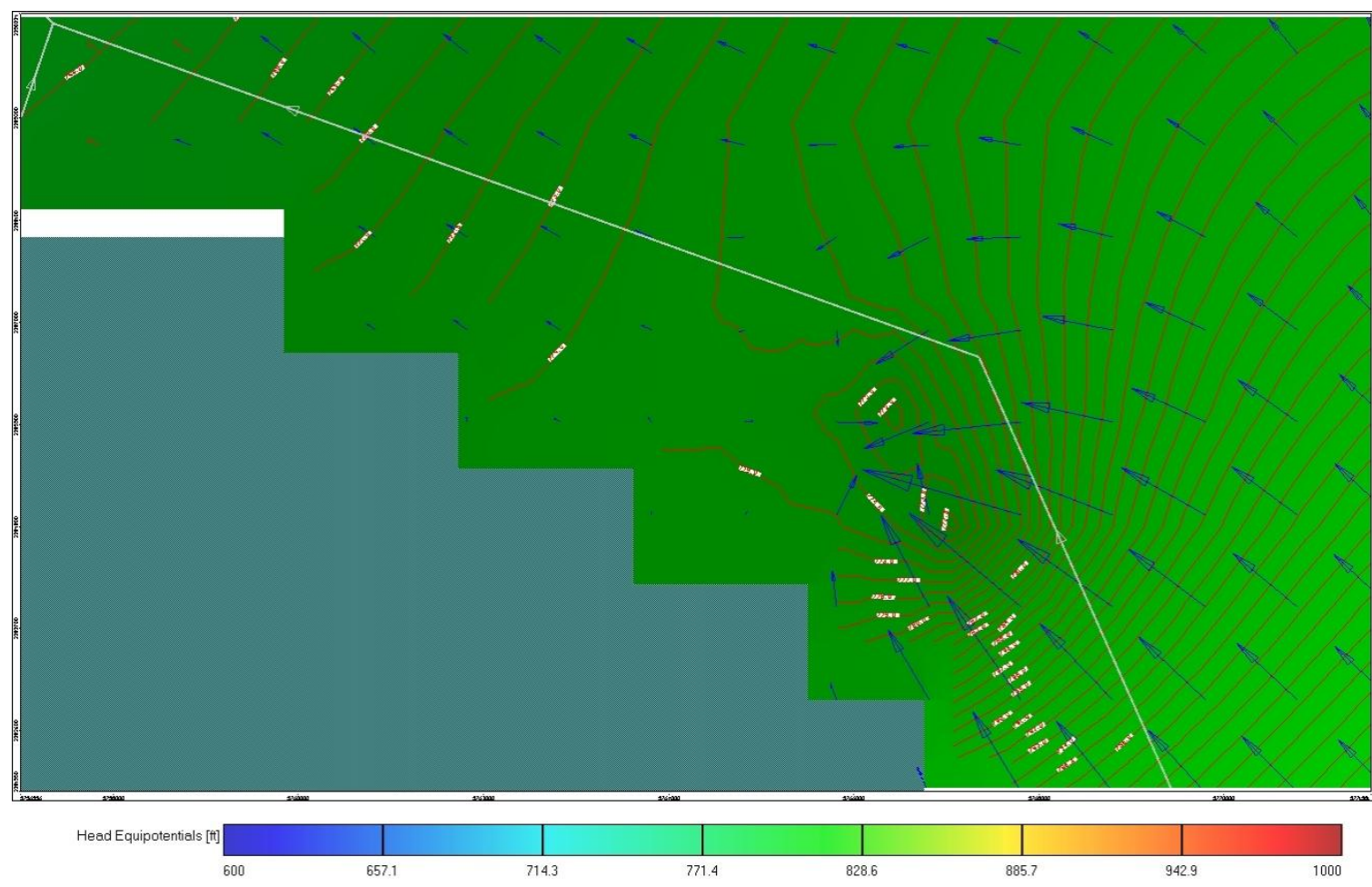

Figure 32. Head contours and flow direction in Layer 3 in Atascadero in April 2009 (Day 3378) 


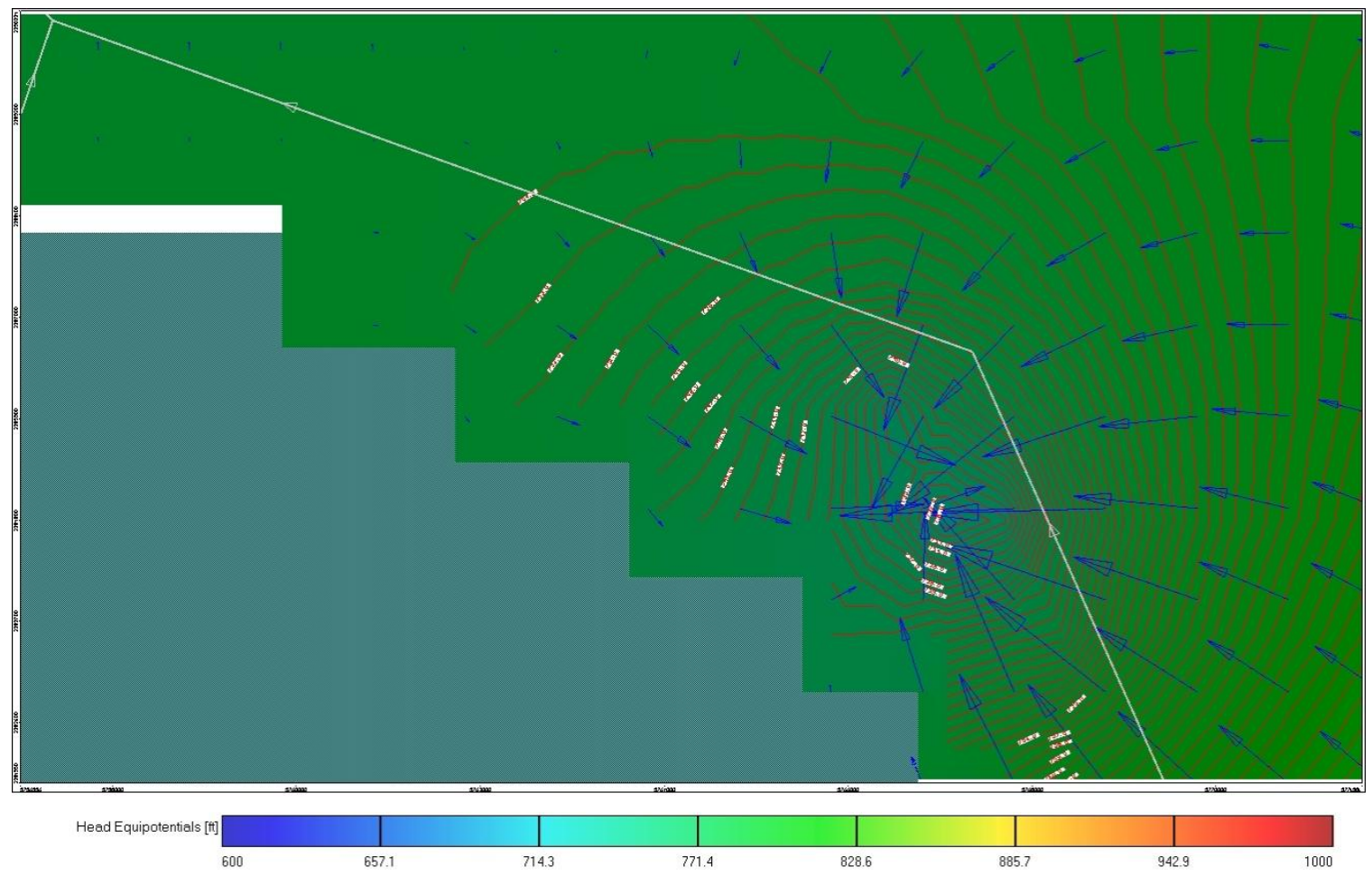

Figure 33. Head contours and flow direction in Layer 3 in Atascadero in October 2009 (Day 3561 )

The head contours and groundwater flow direction in the Atascadero area shows that pumping in both layers causes an effect on the groundwater. The magnitude of the effect depends on the amount of recharge and pumping in a given year. In 2000 the difference in heads was approximately 20 feet in Layer 1 and 25 feet in Layer 3. There is also a noticeable change in flow direction from being directed along the Salinas River, to being directed toward the pumping wells. In 2005, the increased recharge does not appear to drastically increase the heads in either layer as both April 2000 and April 2005 contours are approximately the same. The increased recharge did create an effect on the amount of drawdown in 2005. Difference in heads between April 2005 and October 2005 were approximately 15 feet in Layer 1 and 20 feet in Layer 3. Drastic decreases were seen in Layer 3 in 2009. Due to the extended period with little recharge the head in April 2009 was approximately 15 feet lower than in 2000 and 2005, and then was 
reduced by an additional 40 feet by October 2009. Layer 1 in 2009 showed little change in starting head in April and was reduced by only 10 feet in October 2009, partly due to the fact that the wells in this area were not pumping in this month. The minor decrease in heads, however, could be due to pumping from the deep aquifer drawing water from the River and Layer 1.

Pumping in the Templeton area did now show significant effects on head contours and flow direction. The heads in April of 2000, 2005, and 2009 were all within 15 feet and each year the heads were reduced between 20 and 30 feet. Flow direction was minimally altered in Layer 3 by the three deep pumping wells in this area but was not as drastic as in the Atascadero area. The results from this analysis in the Templeton area suggest this region is going through a consistent annual cycle instead of being in overdraft. Due to the consistency of the Templeton head contours and flow direction, these figures were not included in this report.

The Paso Robles analysis showed that pumping in the area has an effect on the groundwater. This region was different than the rest, however, in that the heads for Layer 3 were higher than Layer 1. This can be expected between an unconfined and confined aquifer as is the case in this scenario. This may also mean that the shallow pumping wells are pumping from the deeper groundwater aquifer as well as from the Salinas River if confining pressure creates a vertically upward gradient from deeper to shallower groundwater. The heads remained fairly consistent during the different years analyzed. In 2005 the heads did increase over the year 2000 heads, but in 2009 heads remained approximately the same as the year 2000 heads. At the end of the dry period in 2009 , the heads for both Layer 1 and Layer 3 were higher than in October 2000. The Salinas River 
appears to be keeping the groundwater levels relatively consistent regardless of the recharge in a given year. The direction of flow did change significantly between wet and dry periods. In wet periods the flow generally followed the path of the River. During dry periods the groundwater movement changed directly toward the groundwater wells in the area, creating a depression in the region of the Thunderbird Wells of the City of Paso Robles. The following figures show the head contours and flow direction from the Paso Robles area analysis.

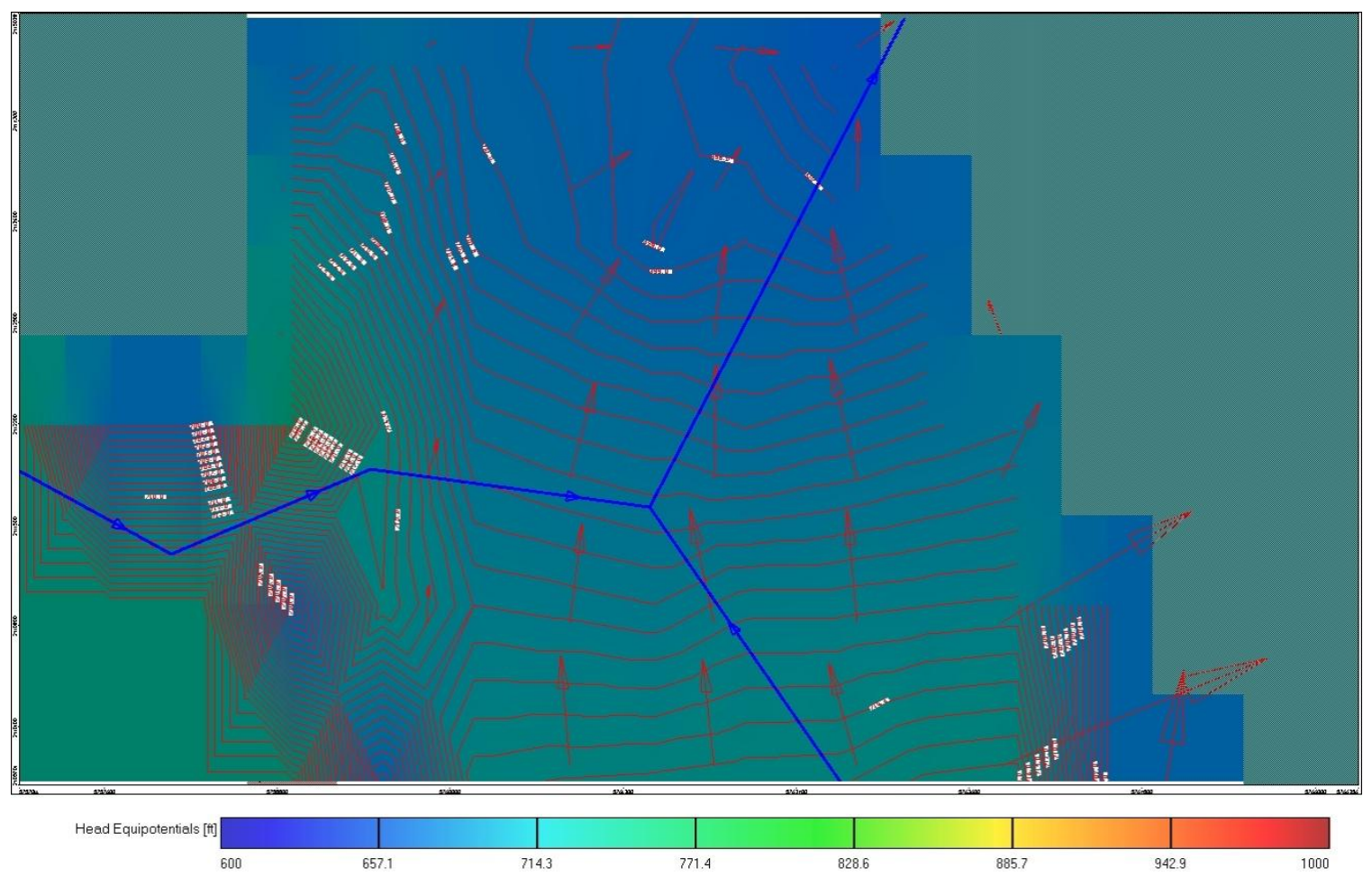

Figure 34. Head contours and flow direction in Layer 1 in Paso Robles in April 2000 (Day 90) 


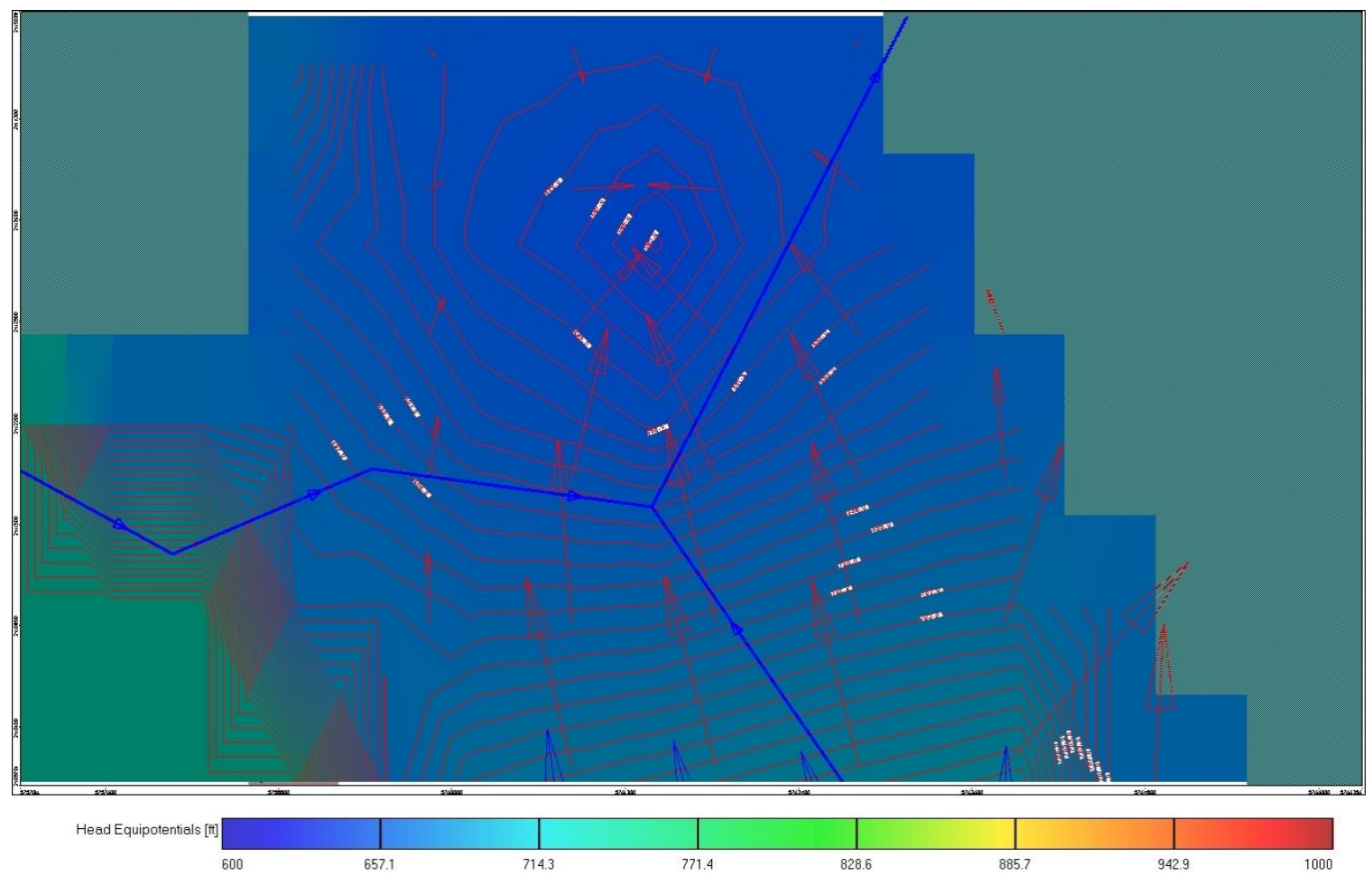

Figure 35. Head contours and flow direction in Layer 1 in Paso Robles in October 2000 (Day 273)

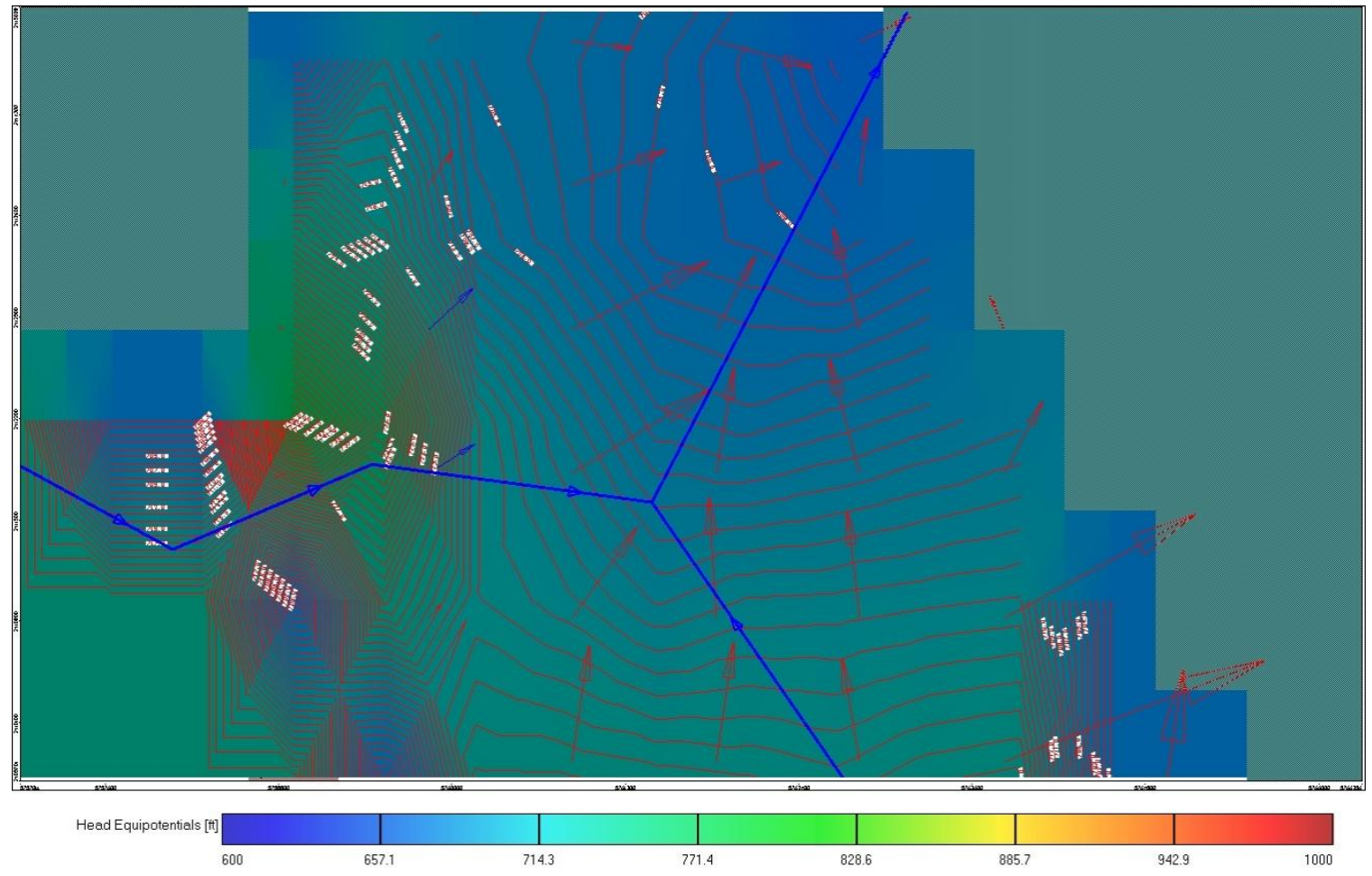

Figure 36. Head contours and flow direction in Layer 1 in Paso Robles in April 2005 (Day 1917) 


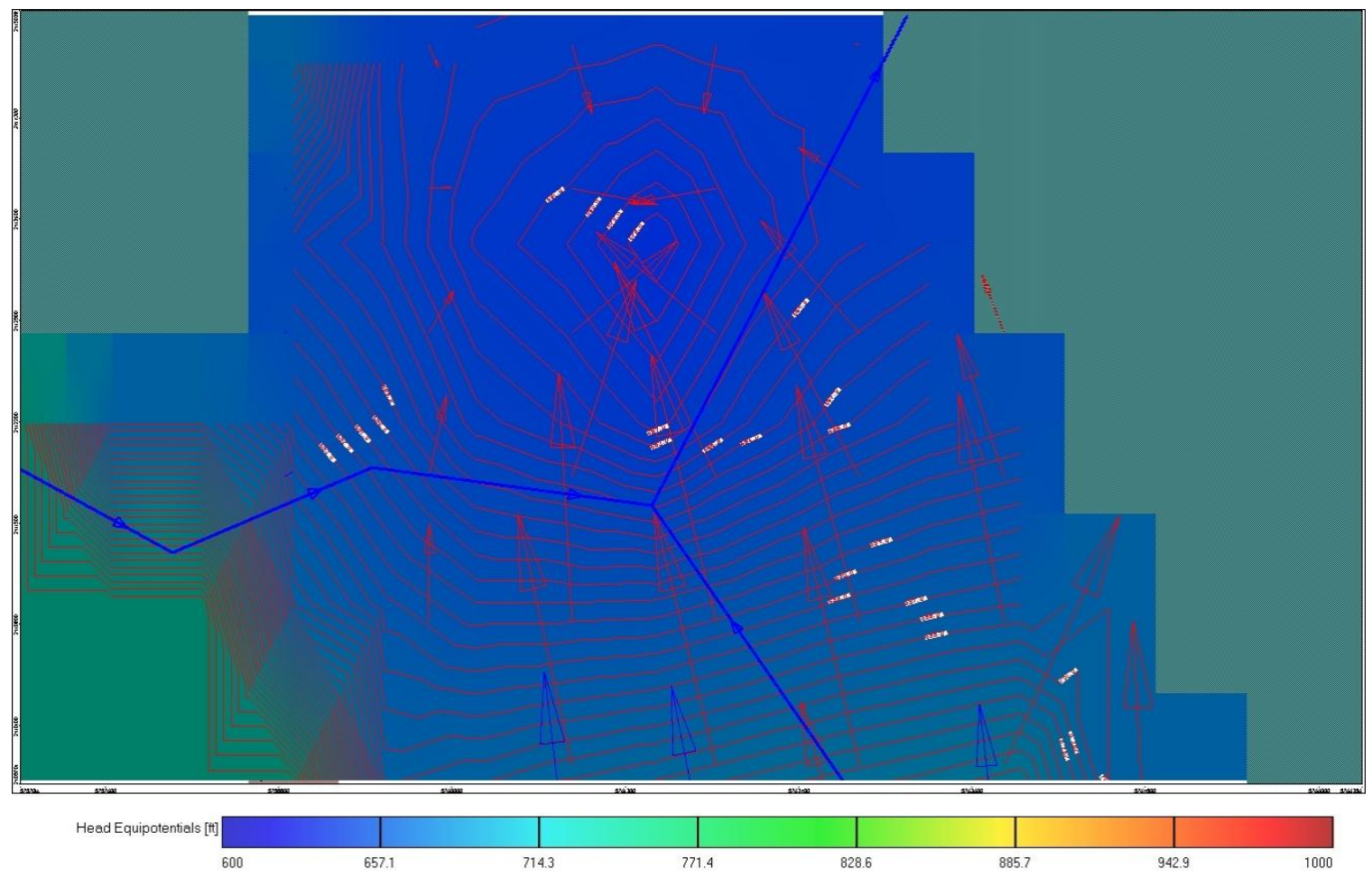

Figure 37. Head contours and flow direction in Layer 1 in Paso Robles in October 2005 (Day 2100)

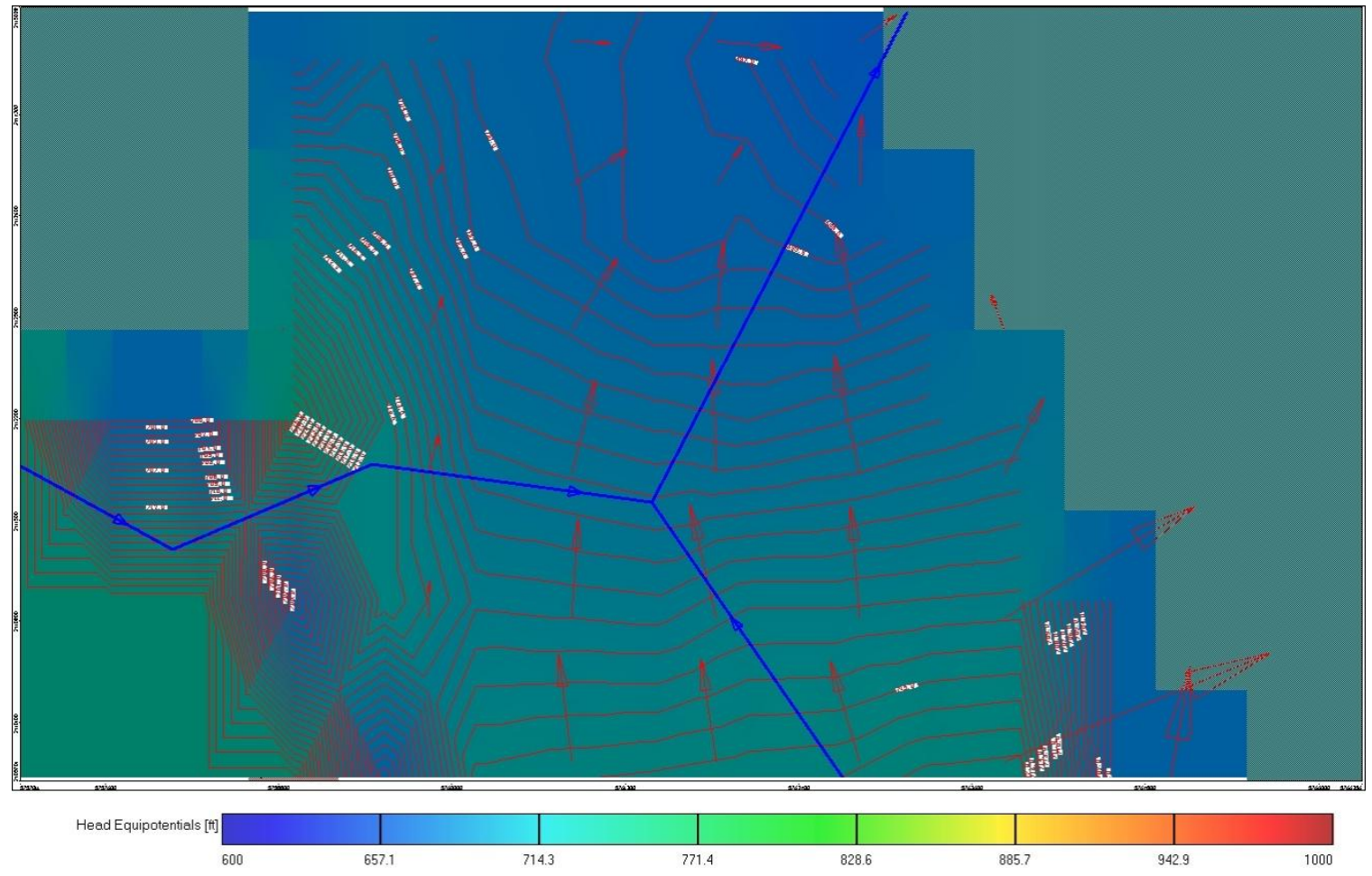

Figure 38. Head contours and flow direction in Layer 1 in Paso Robles in April 2009 (Day 3378) 


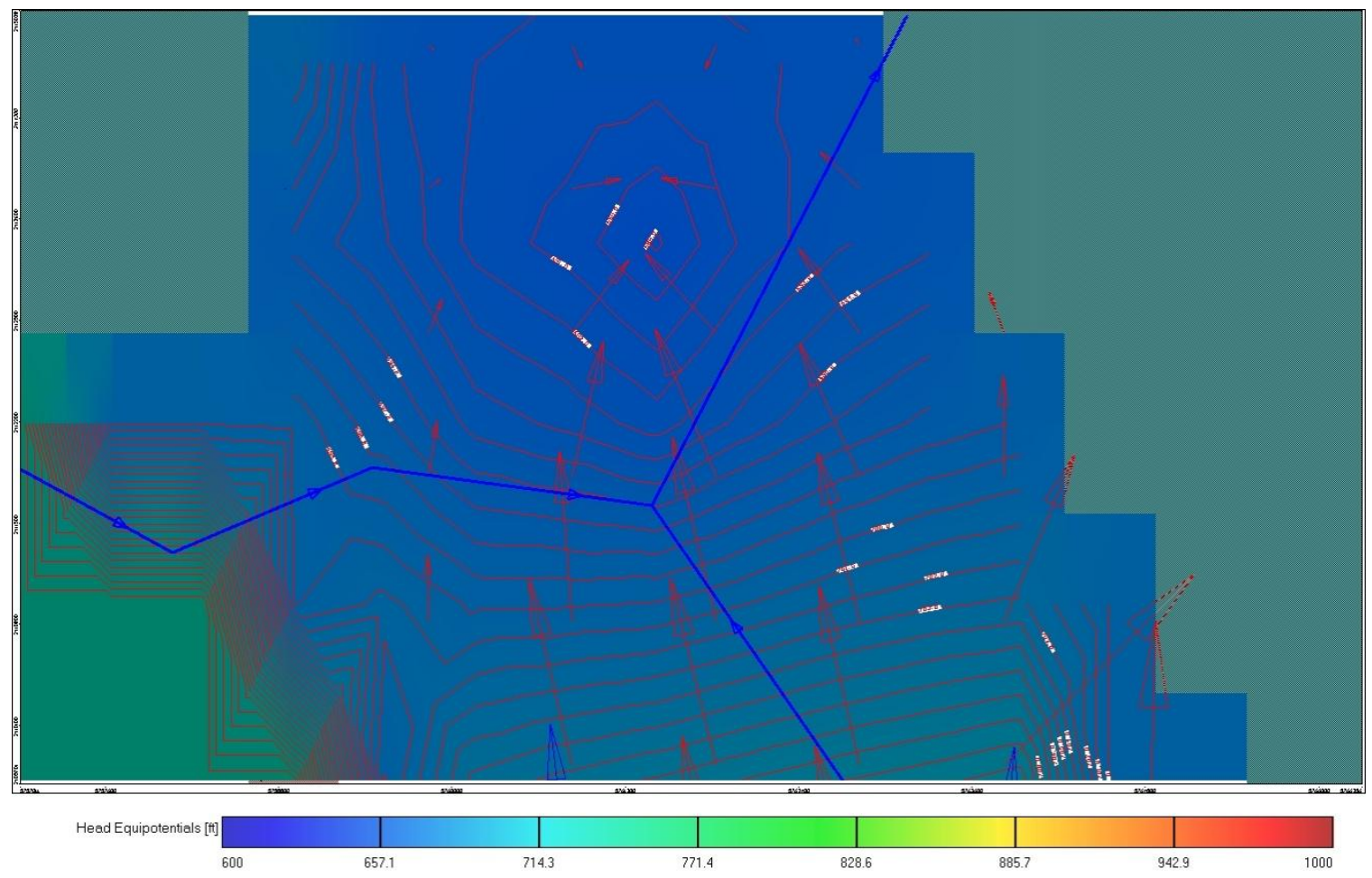

Figure 39. Head contours and flow direction in Layer 1 in Paso Robles in October 2009 (Day 3561)

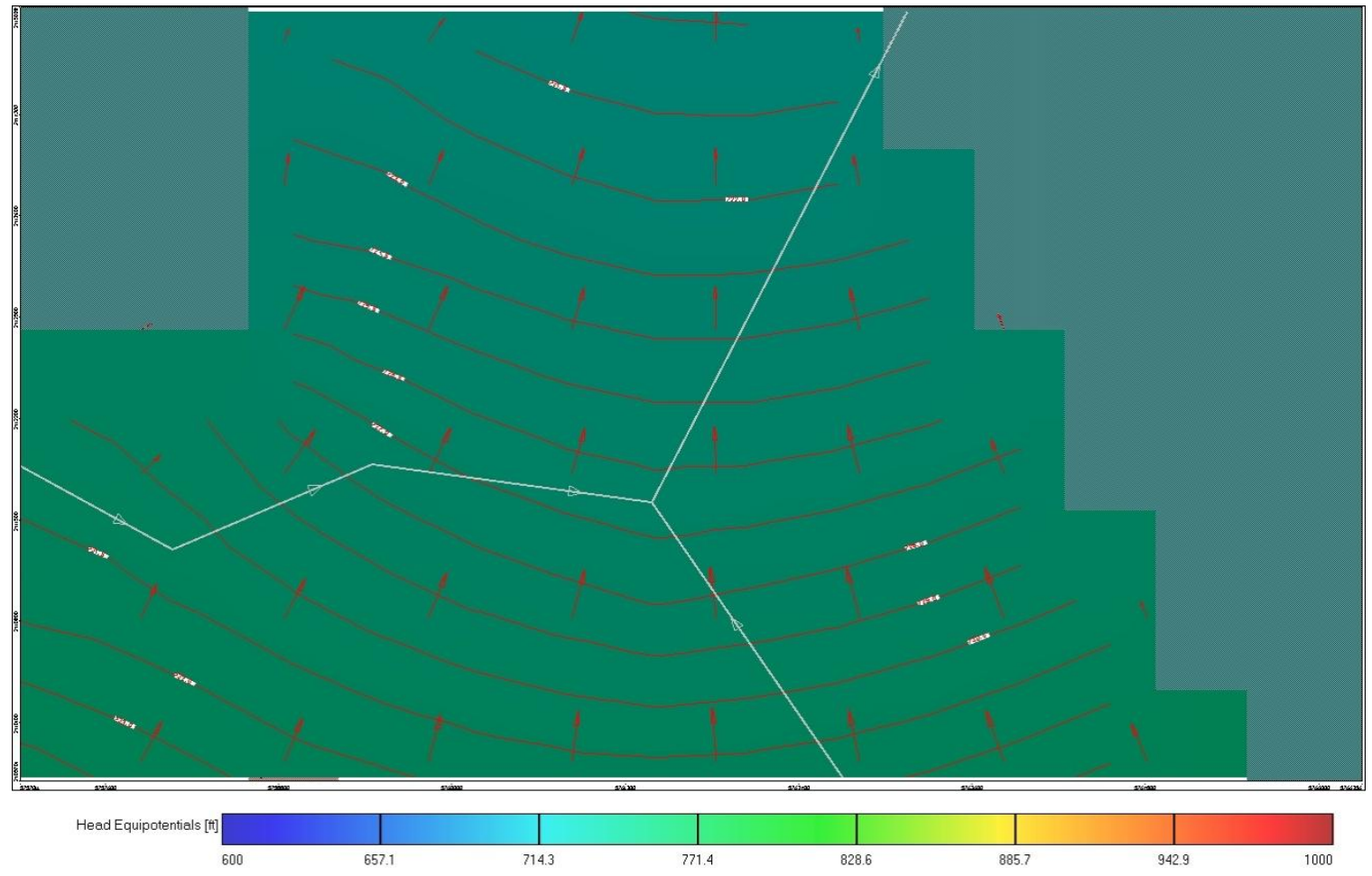

Figure 40. Head contours and flow direction in Layer 3 in Paso Robles in April 2000 (Day 90) 


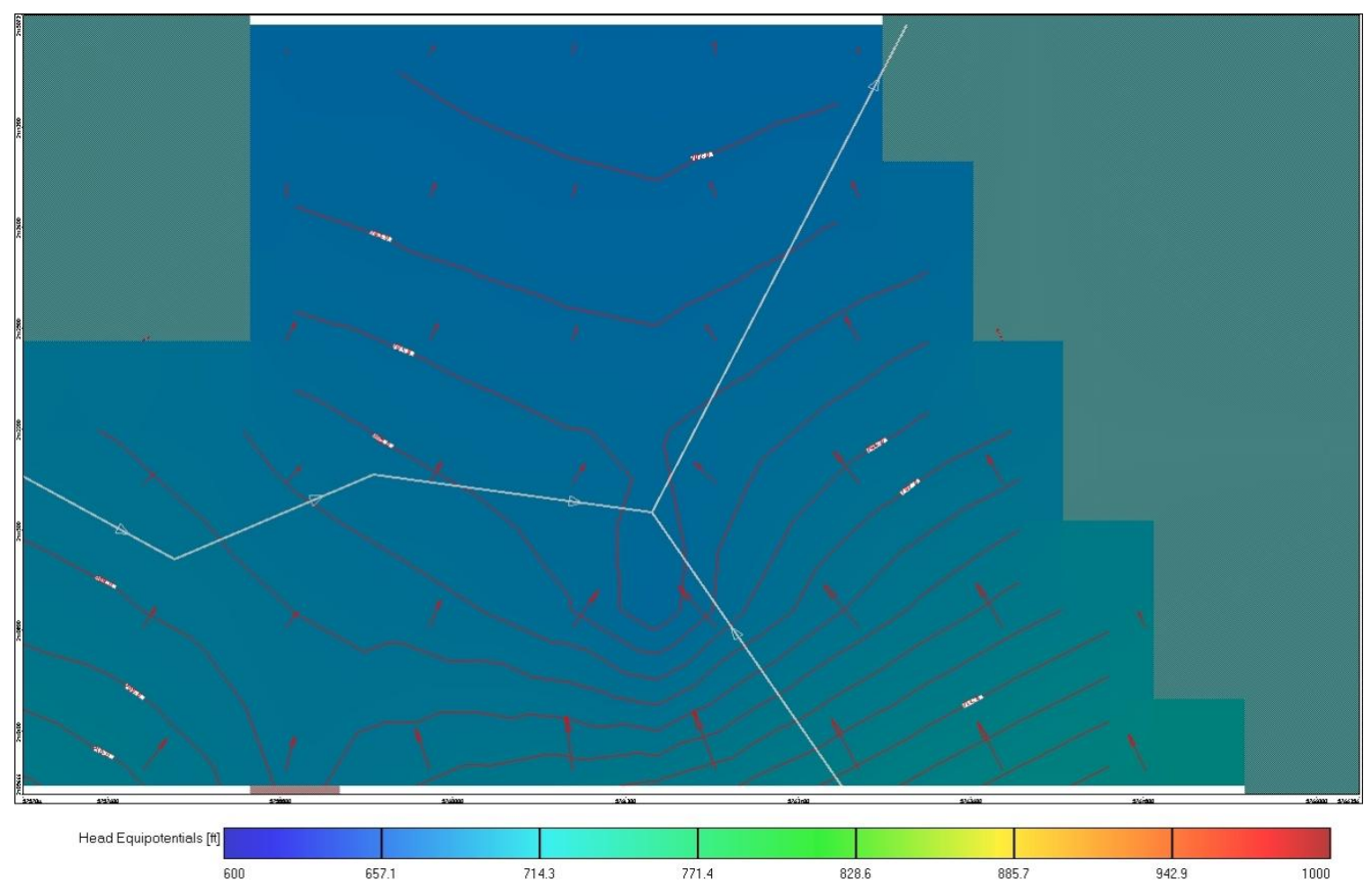

Figure 41. Head contours and flow direction in Layer 3 in Paso Robles in October 2000 (Day 273)

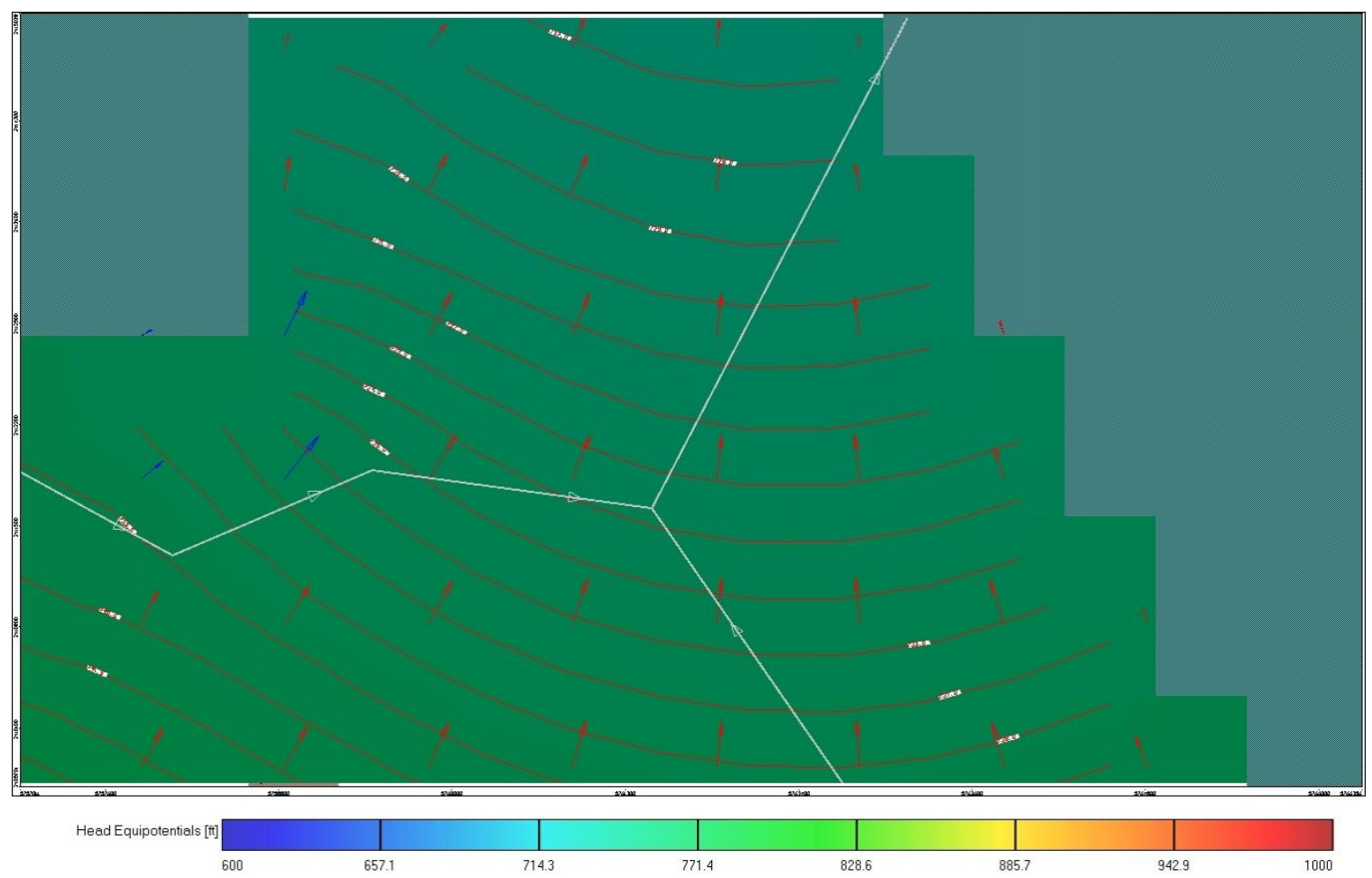

Figure 42. Head contours and flow direction in Layer 3 in Paso Robles in April 2005 (Day 1917) 


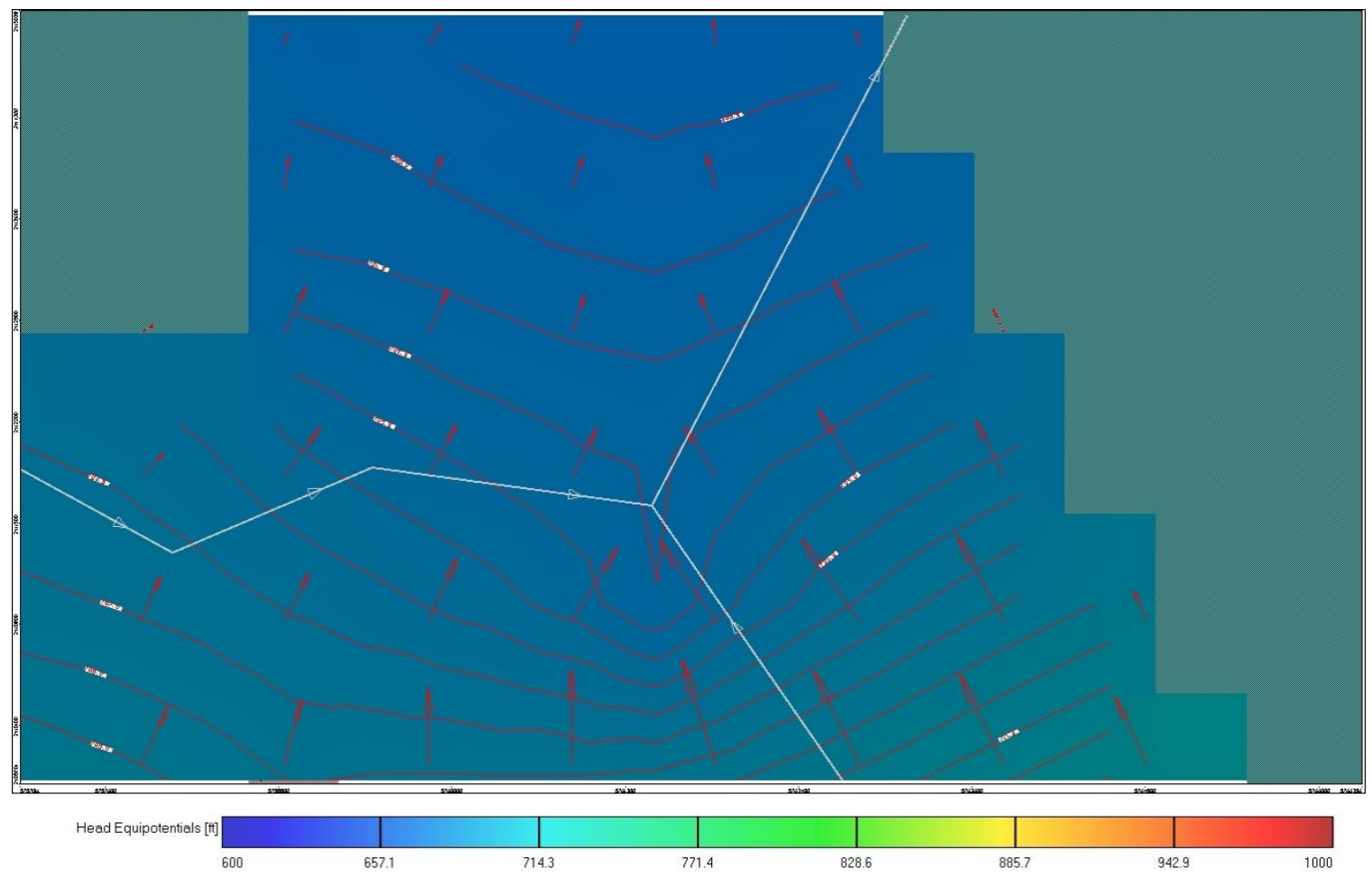

Figure 43. Head contours and flow direction in Layer 3 in Paso Robles in October 2005 (Day 2100)

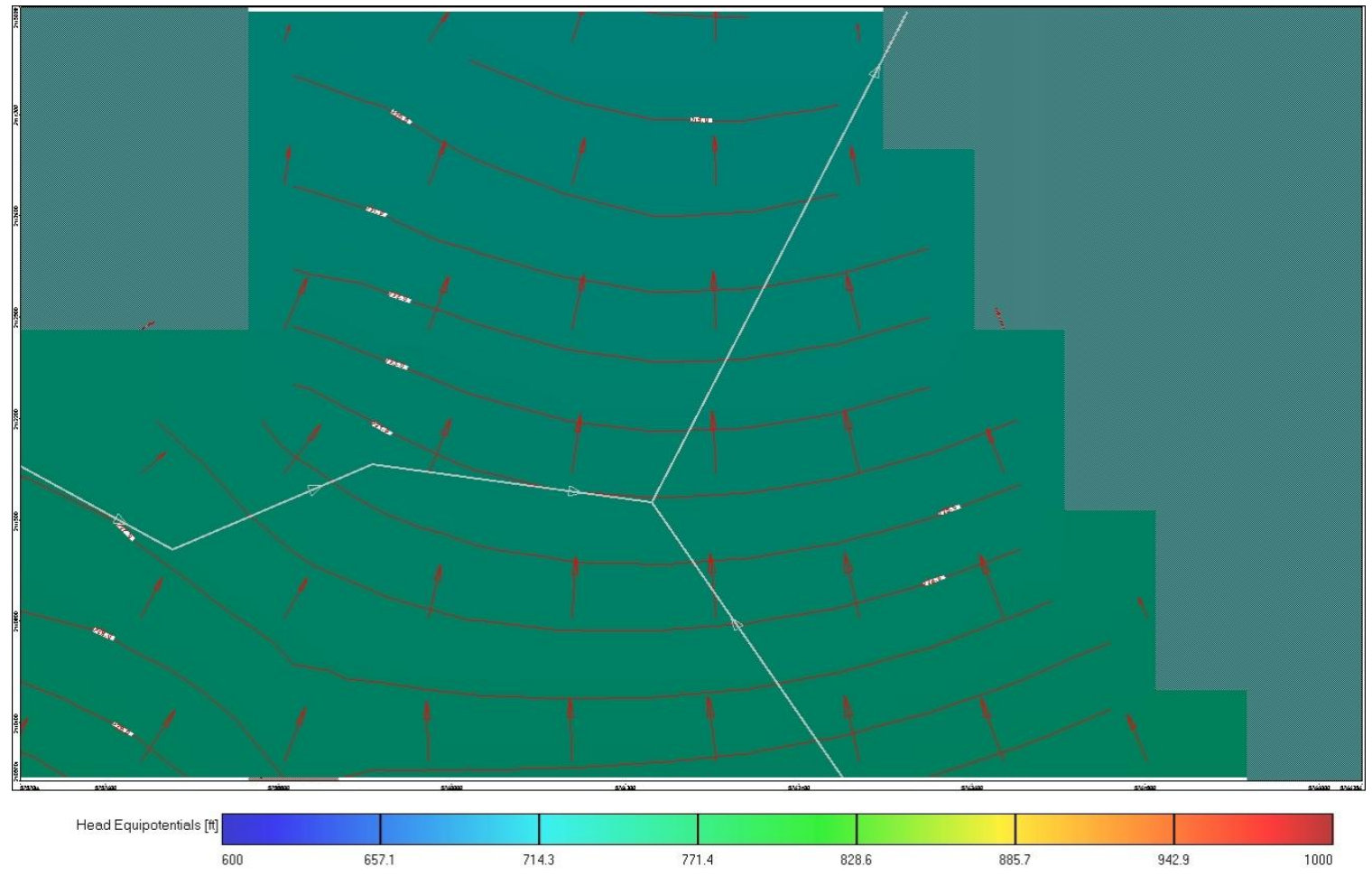

Figure 44. Head contours and flow direction in Layer 3 Paso Robles in April 2009 (Day 3378) 


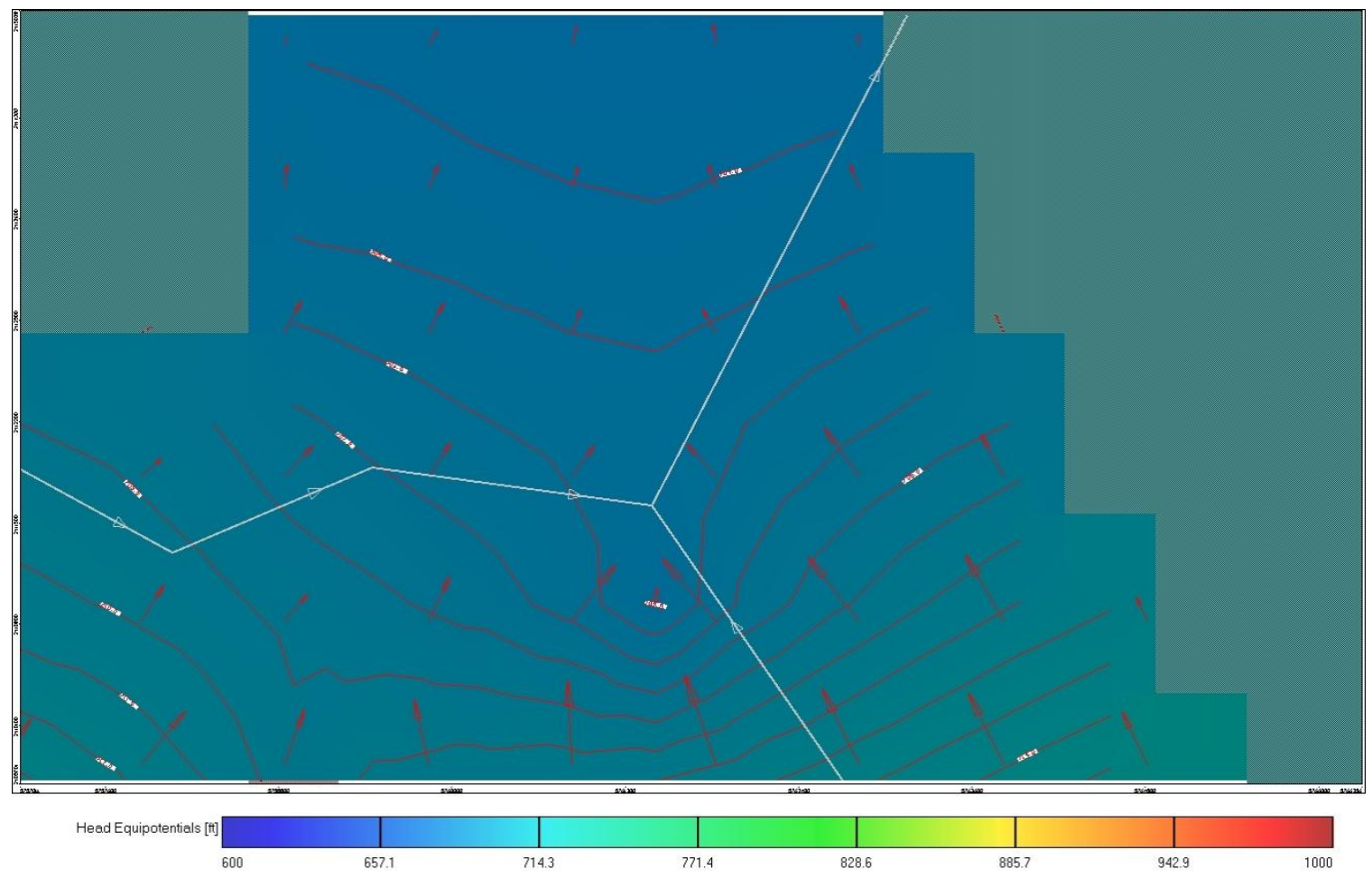

Figure 45. Head contours and flow direction in Layer 3 in Paso Robles in October 2009 (Day 3561)

The second analysis was a review of time series data for representative wells in the area. The wells chosen as representatives were: the AMWC 11 observation well in the Atascadero area, the Davis well in Templeton, and the Platz River well near the Thunderbird wells in Paso Robles. These wells were chosen based upon their location in the Subbasin and the amount of data available at the well. Wells with more data were chosen. All three plots show that the simulated and observed results track reasonably well the first half of the period, but the simulated model is consistently higher than observed data. As observation data decreases with the extended dry period the simulated and observed points begin to become further apart. This suggests that the locations for possible overdraft issues found through the first analysis (in Atascadero and Paso Robles) could be more of a problem with larger decreases in heads and more drastic changes in 
flow direction than what the model is predicting. Plots of head versus time for the 2000 to 2009 period are shown in the following figures.

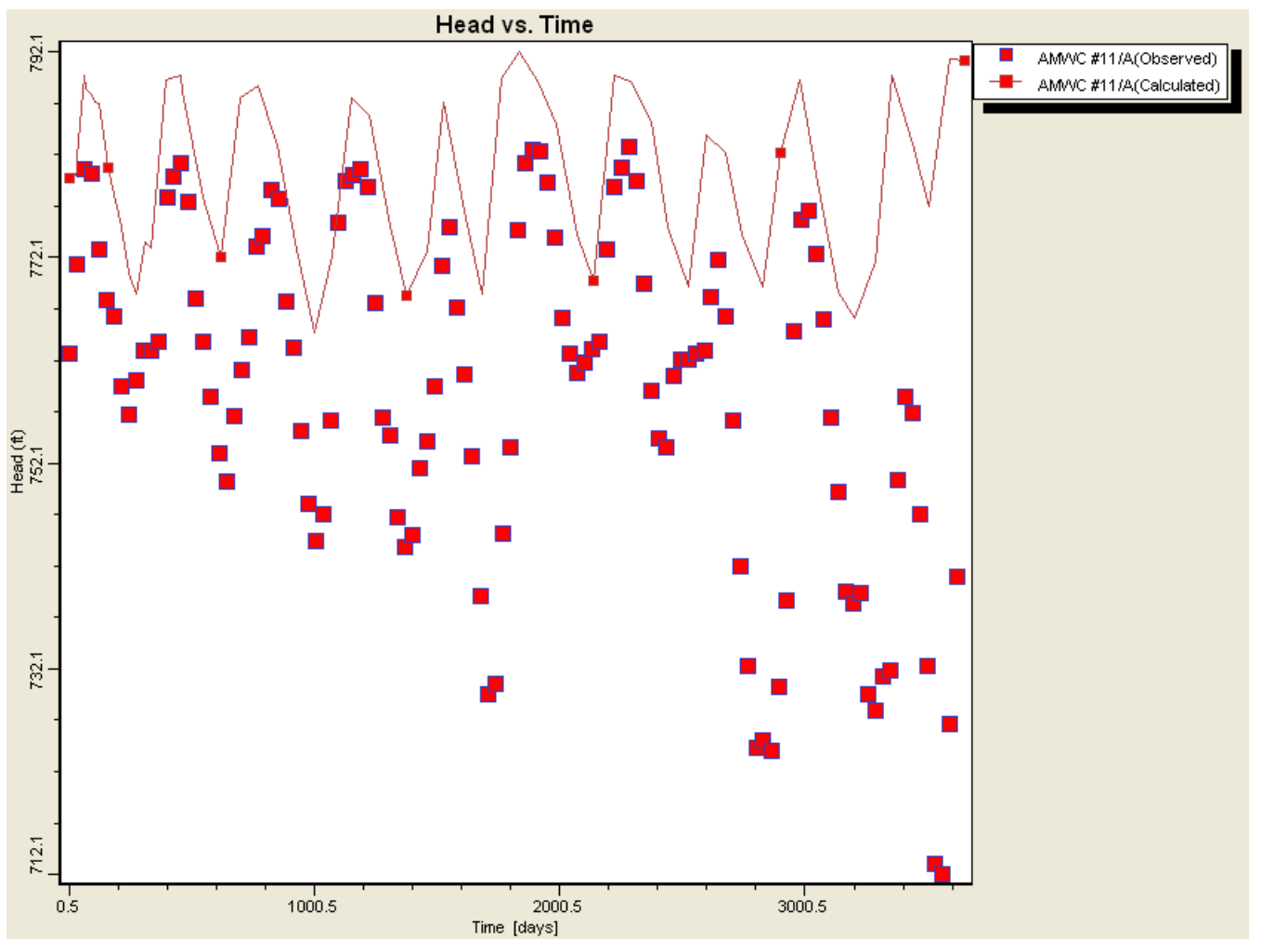

Figure 46. Observed and Simulated head versus time for AMWC 11 


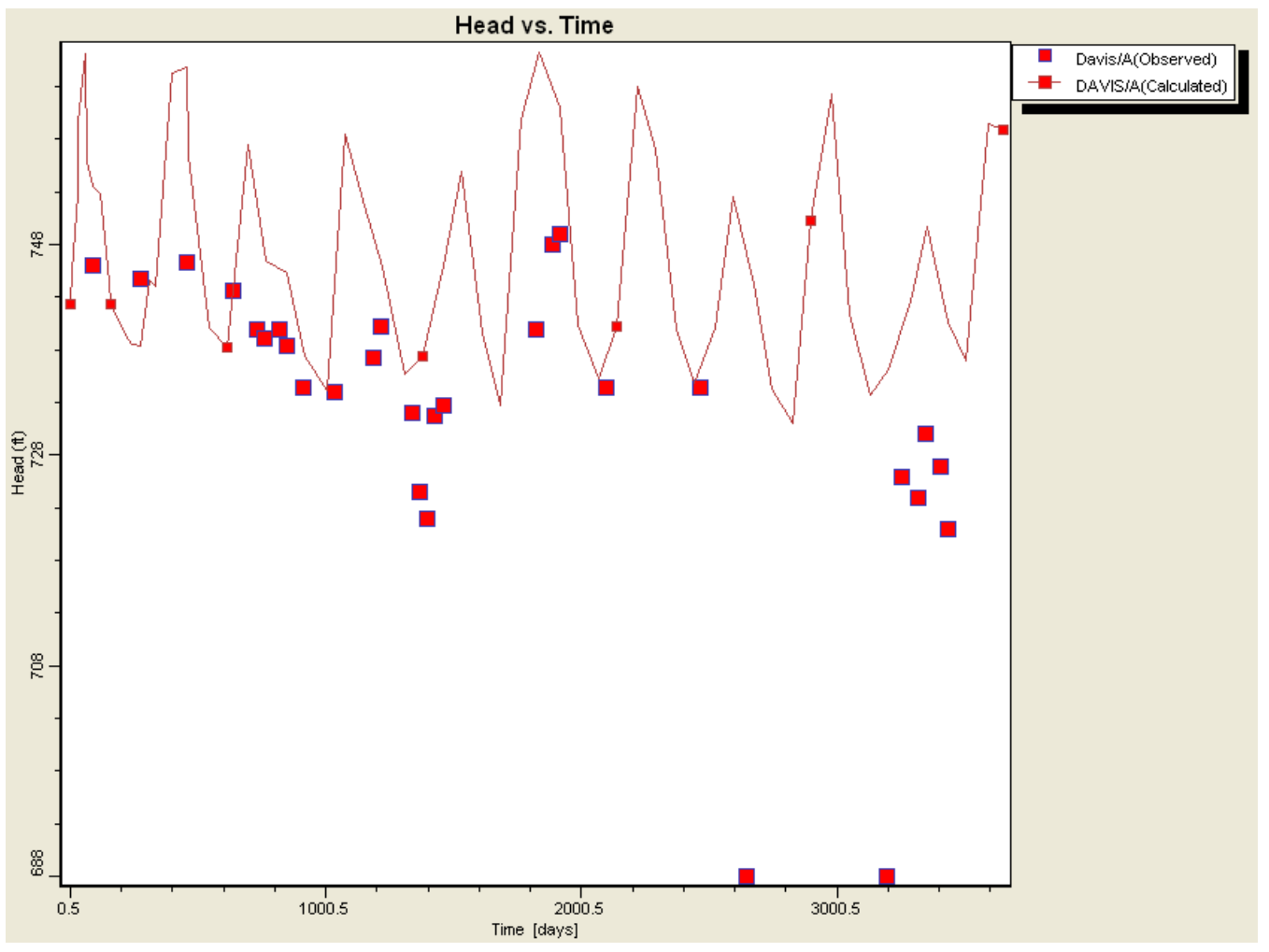

Figure 47. Observed and Simulated head versus time for Davis well 


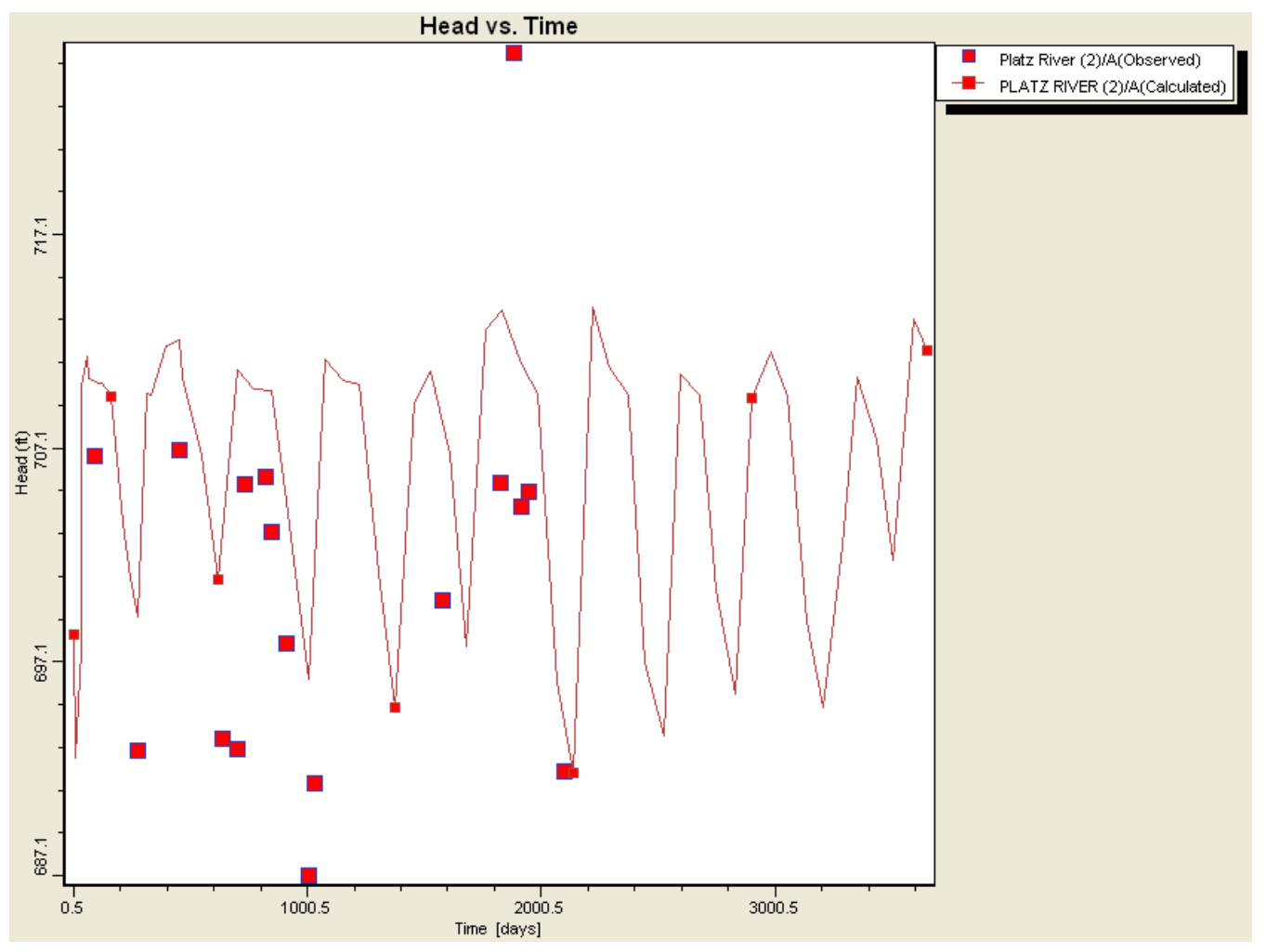

Figure 48. Observed and Simulated head versus time for Platz River well

The third and final analysis performed was to increase the amount of pumping in the Subbasin by $10 \%$ and $20 \%$ to simulate how the Subbasin would react to increases in demand. These increases in pumping can be seen as a simulation of increased demand due to population, industrial or agricultural growth. This analysis will be helpful in determining if the Subbasin can be sustainable with increased pumping assuming the hydrology stays the same.

The results from this analysis showed that as pumping increases a larger area of the aquifer is affected both in depth and areal extent. Overall the drawdown increases as more groundwater is pumped. This is evident in the pumping regions around Atascadero and Paso Robles. In Atascadero drawdown increased approximately five feet with the 
$10 \%$ increase in pumping. During the $20 \%$ increase in pumping drawdown increased to more than ten feet, with the worst case being an additional 15 feet of drawdown in October 2009. The increased pumping also reduced the rebound in wet periods. In April of 2009 , head values were up to eight feet lower with the increases in pumping. Results in the Paso Robles area were similar. Drawdown was increased by over 10 feet in Layer 1 due to pumping increases. The Templeton area resulted in increased drawdown in dry periods but was able to rebound to be near the initial levels at the end of each wet period. Additional drawdown of 10 to 15 feet in the Atascadero and Paso Robles areas is not thought of as a large reduction for overdraft, but with only an additional 10-20\% in well production, drawdown changes up to $50 \%$ in some locations. Along with the additional drawdown the influence these wells have when pumping begins to increase substantially. In both Layers 1 and 3 in the Atascadero region a larger sphere of influence is created as the aquifer tries to satisfy demand. This also occurs in the Paso Robles area, primarily in Layer 1 . The influence creates more seepage from surface water and localized changes in the groundwater movement trend. This becomes more significant during dry periods with less recharge. The following figures show increases in both drawdown and influence for different time periods in the Atascadero and Paso Robles regions. 


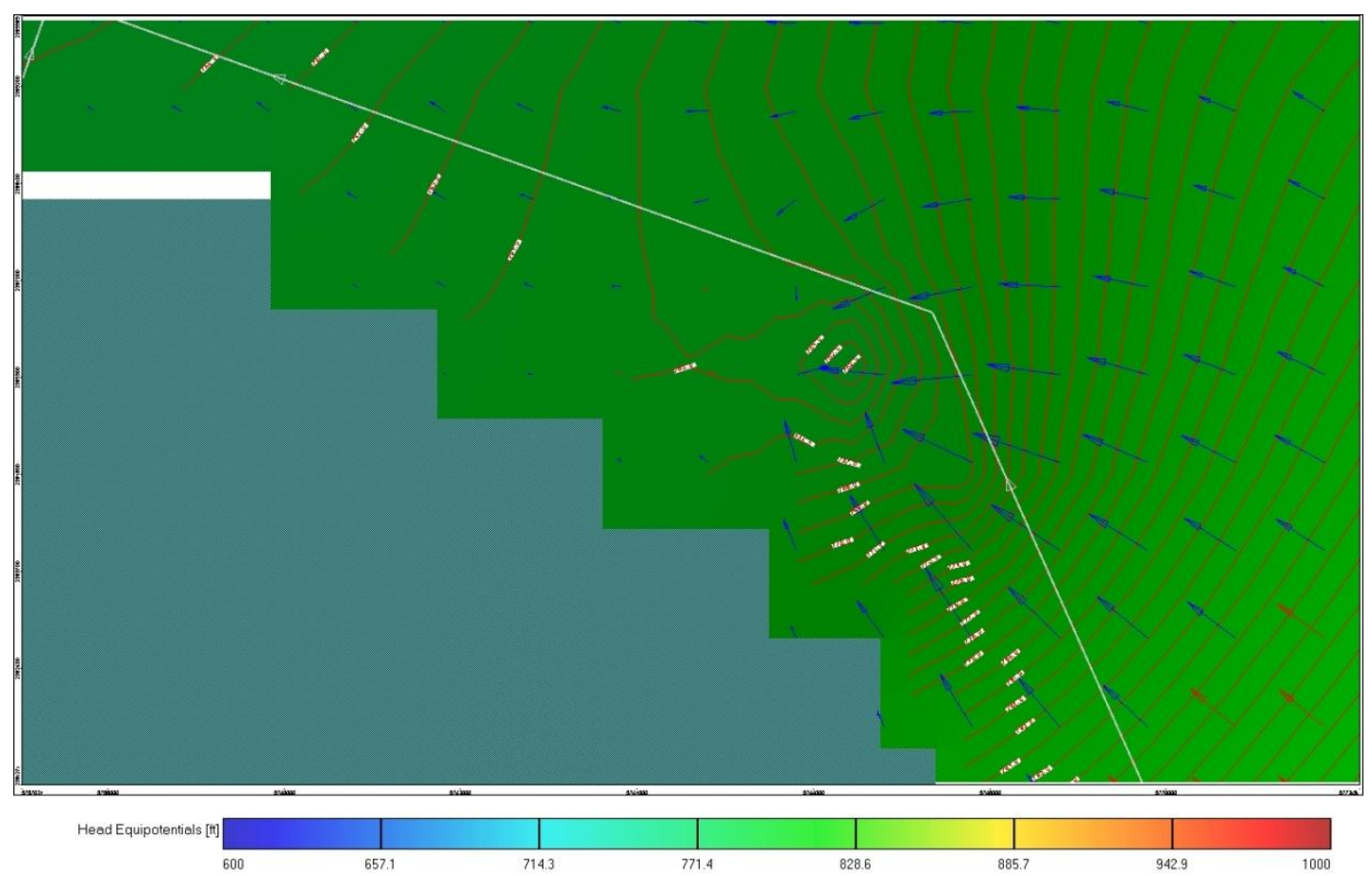

Figure 49. 10\% increase in pumping in October 2000 showing additional drawdown and influence near Atascadero in Layer 3

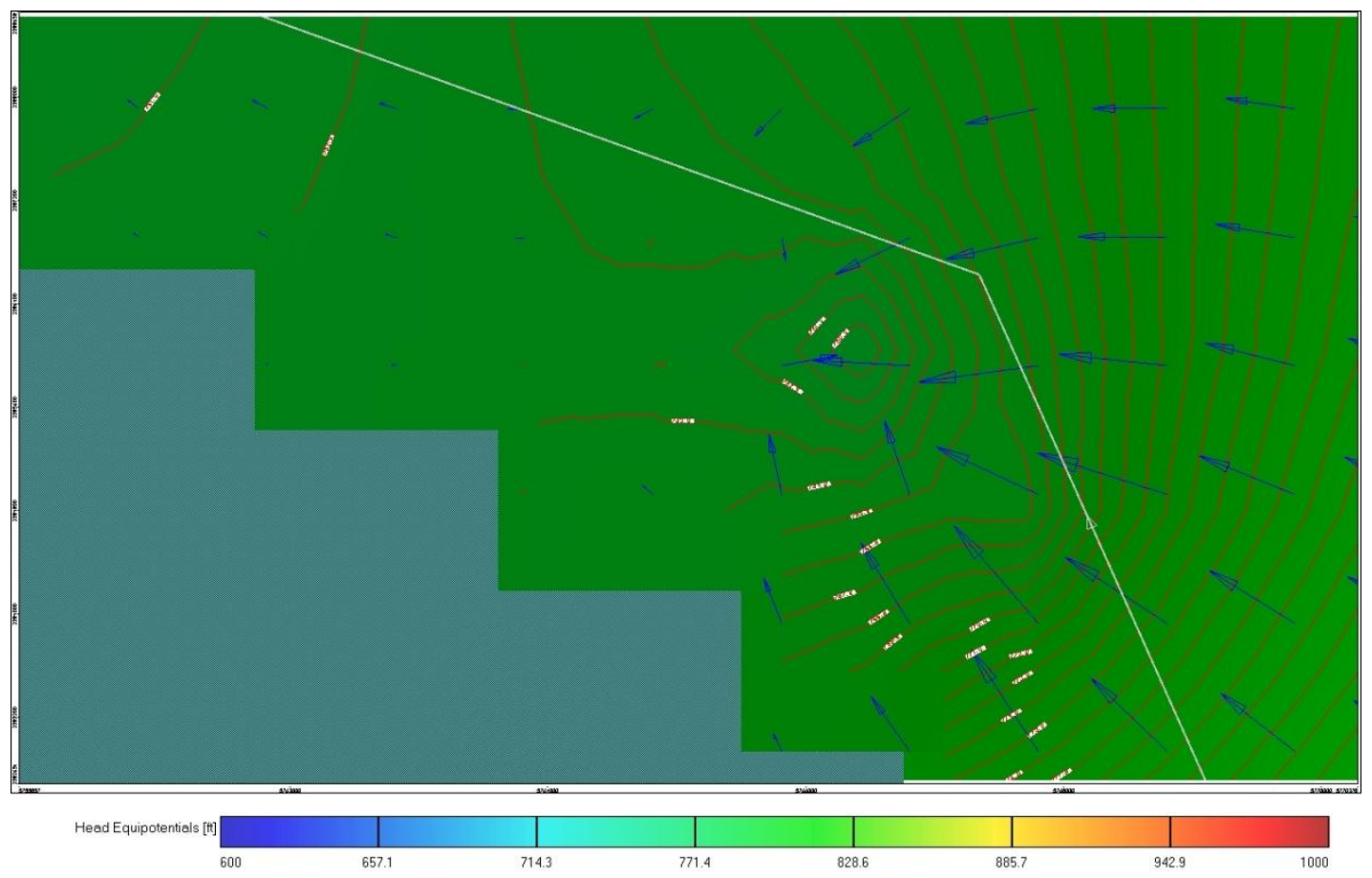

Figure $50.20 \%$ increase in pumping in October 2000 showing additional drawdown and influence near Atascadero in Layer 3 


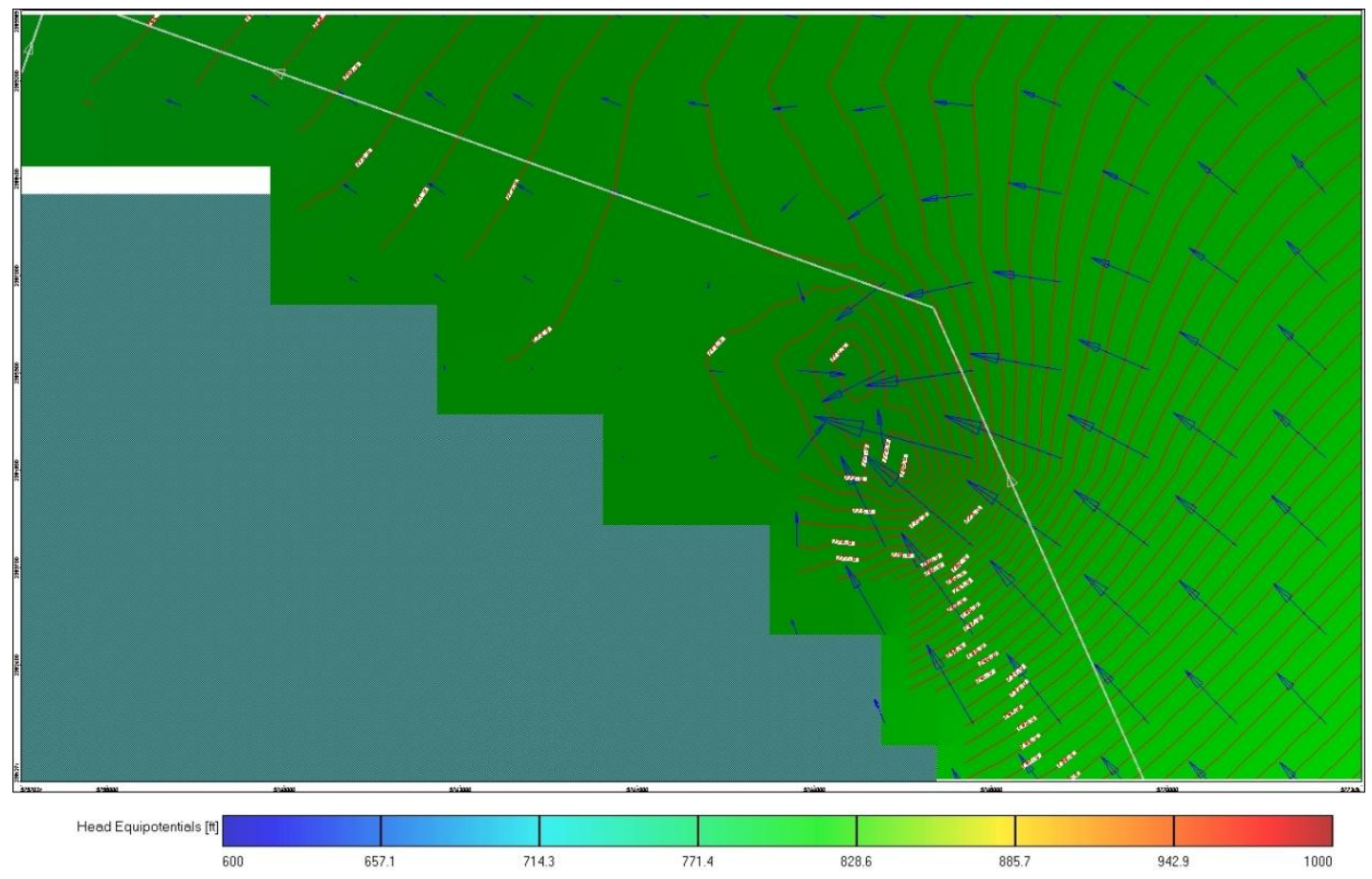

Figure 51. 10\% increase in pumping in April 2009 showing additional drawdown and influence near Atascadero in Layer 3

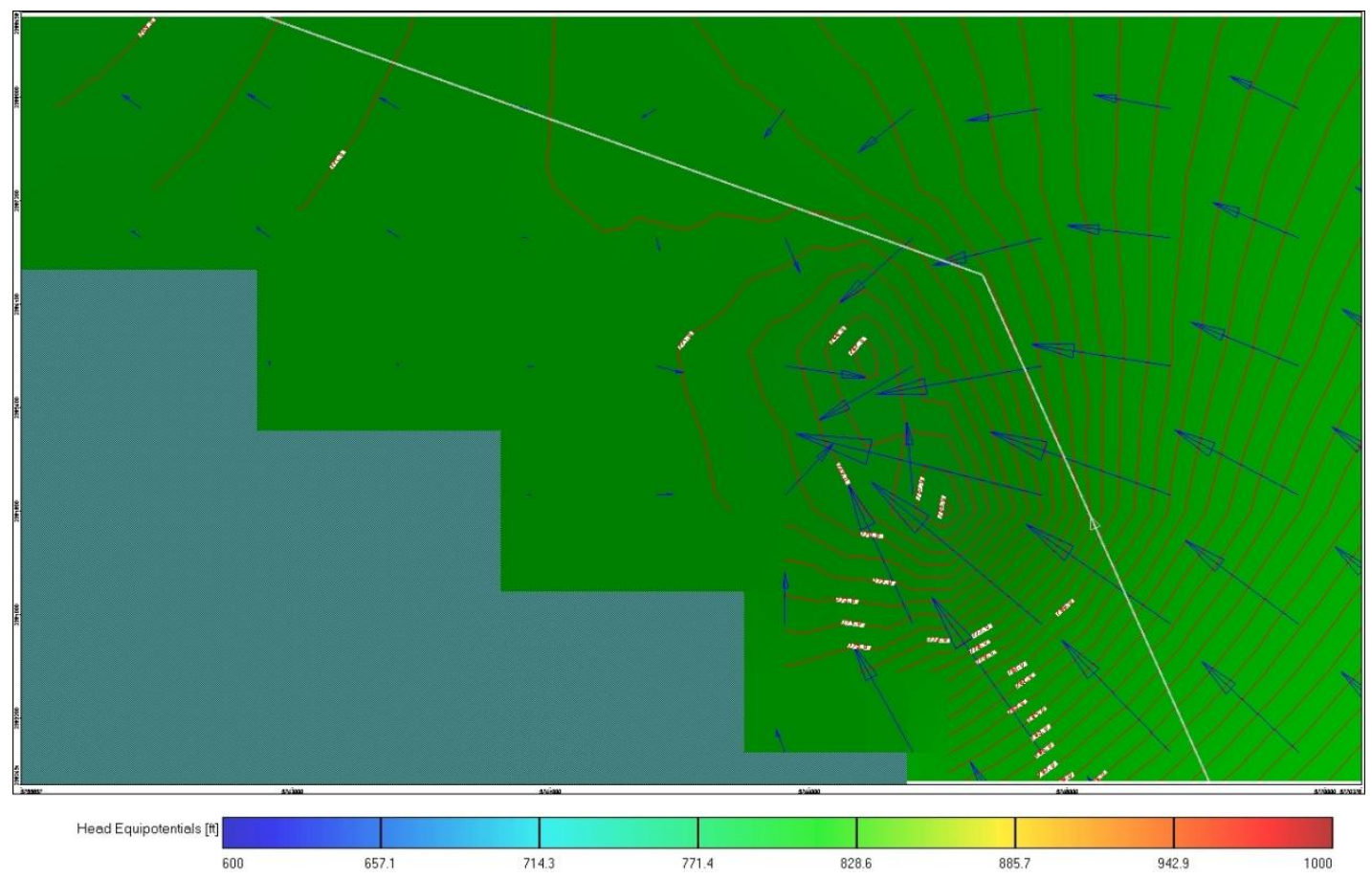

Figure 52. 20\% increase in pumping in April 2009 showing additional drawdown and influence near Atascadero in Layer 3 


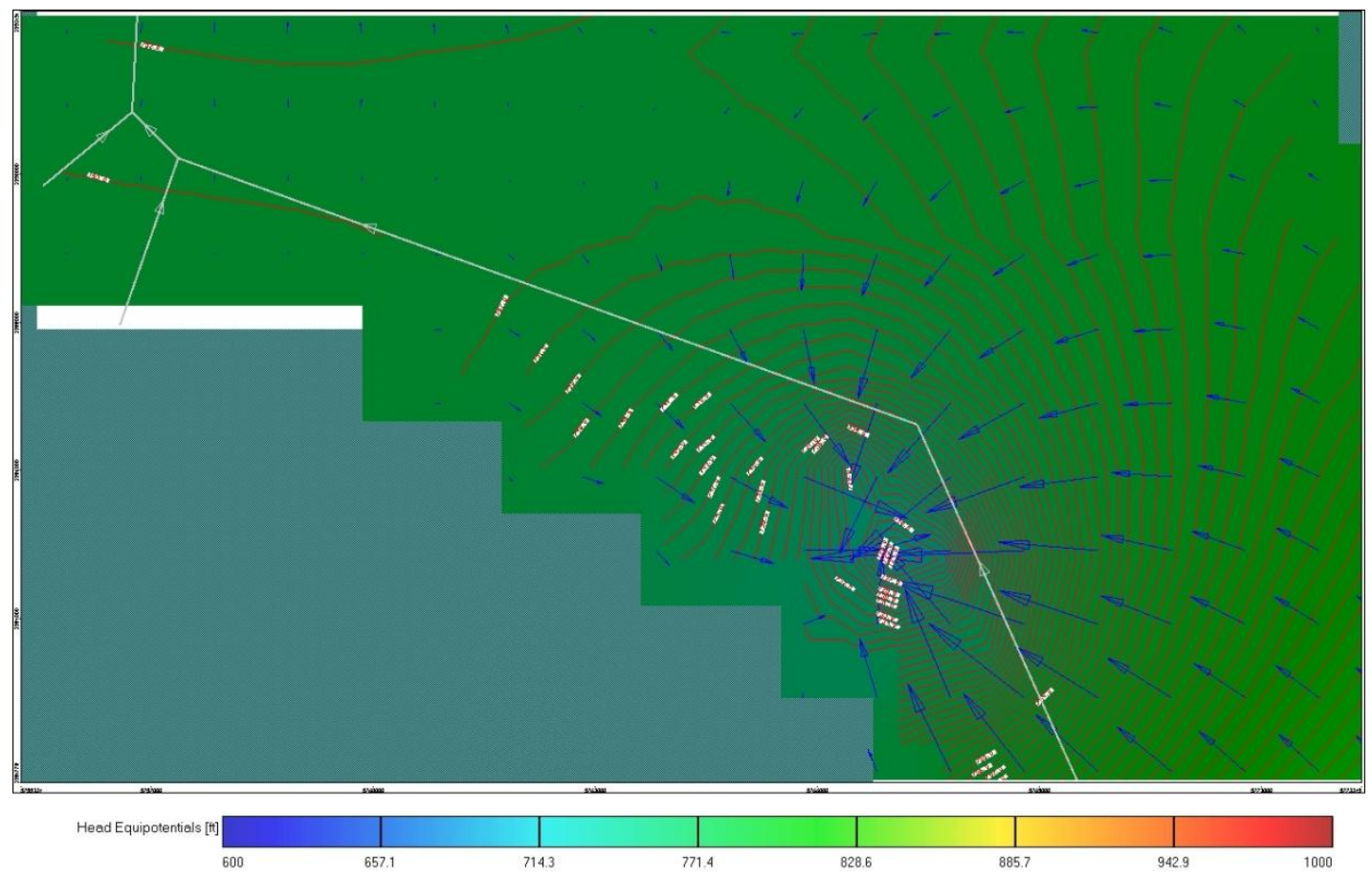

Figure 53. 10\% increase in pumping in October 2009 showing additional drawdown and influence near Atascadero in Layer 3

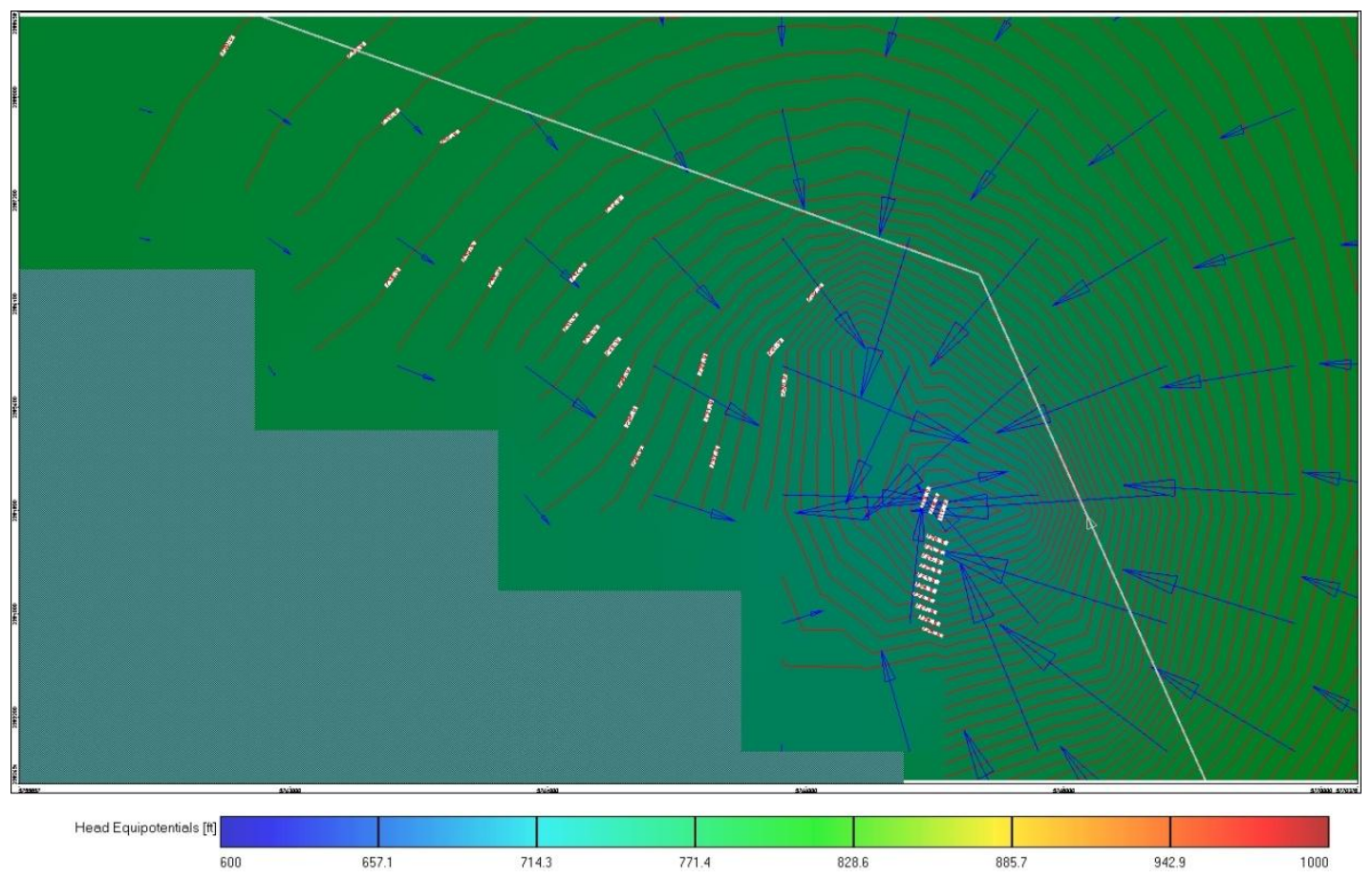

Figure 54. 20\% increase in pumping in October 2009 showing additional drawdown and influences near Atascadero in layer 3 


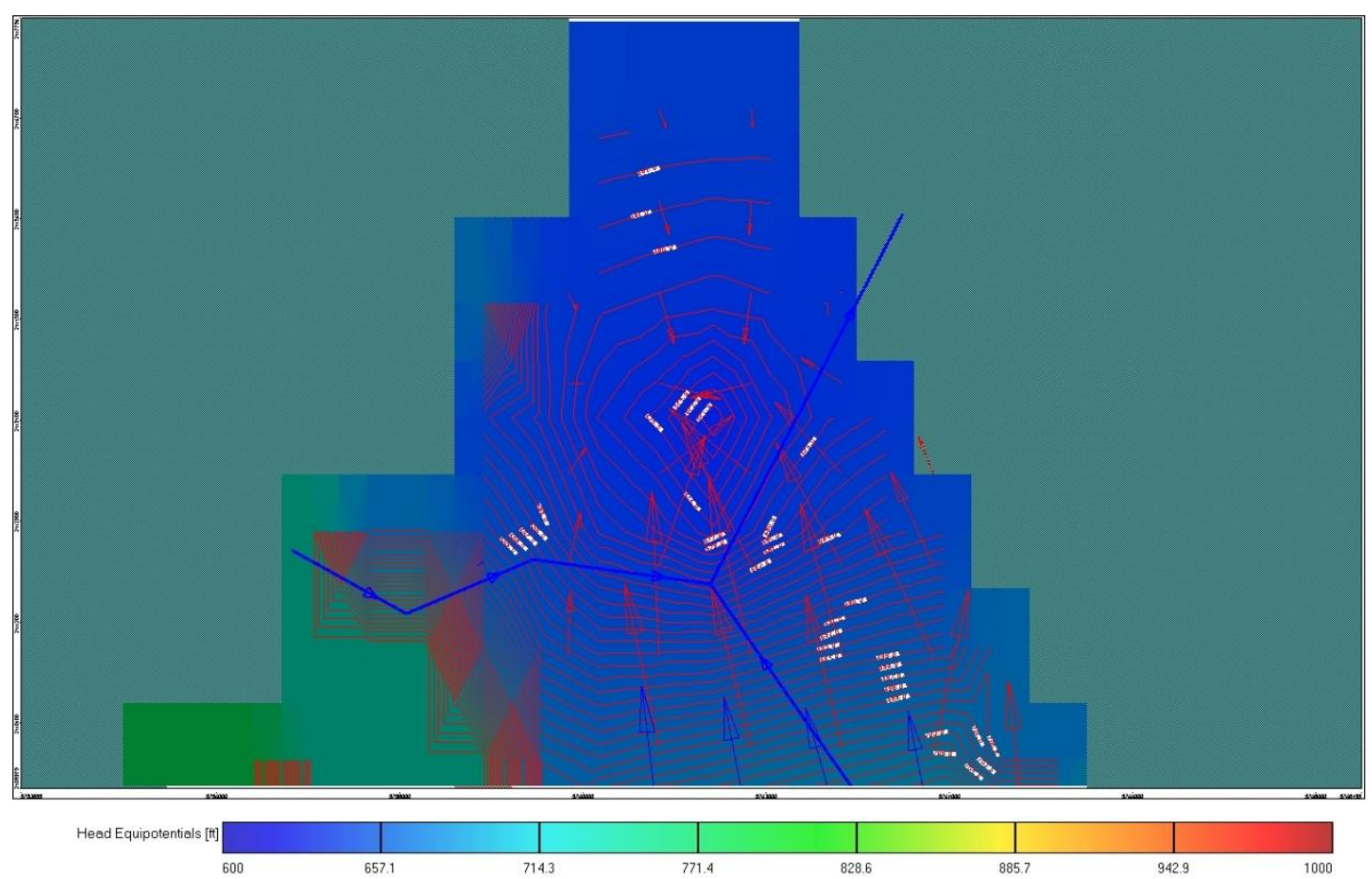

Figure 55. 10\% increase in pumping in October 2005 showing additional drawdown and influence near Paso Robles in Layer 1

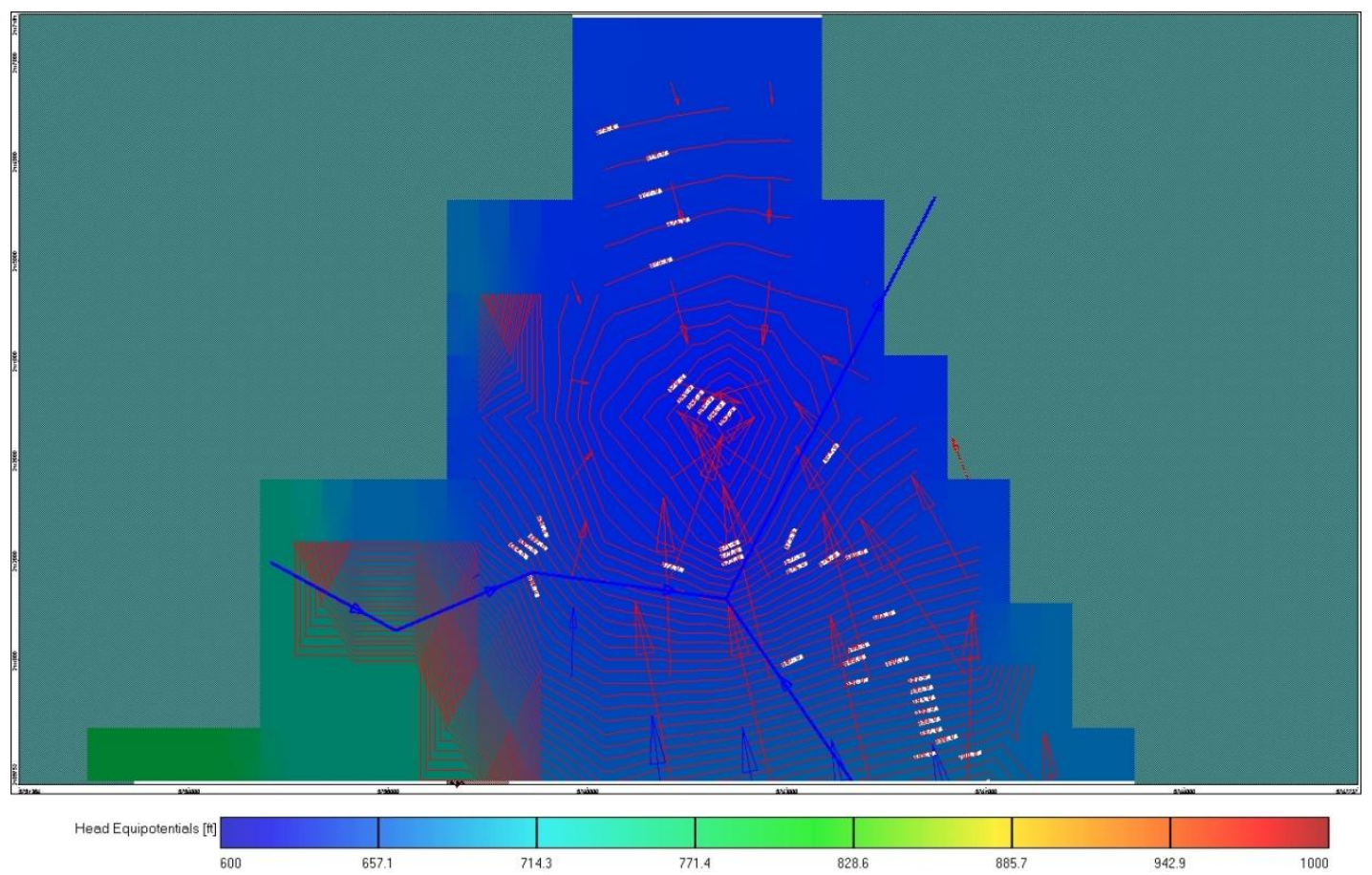

Figure 56. 20\% increase in pumping in October 2005 showing additional drawdown and influence near Paso Robles in Layer 1 


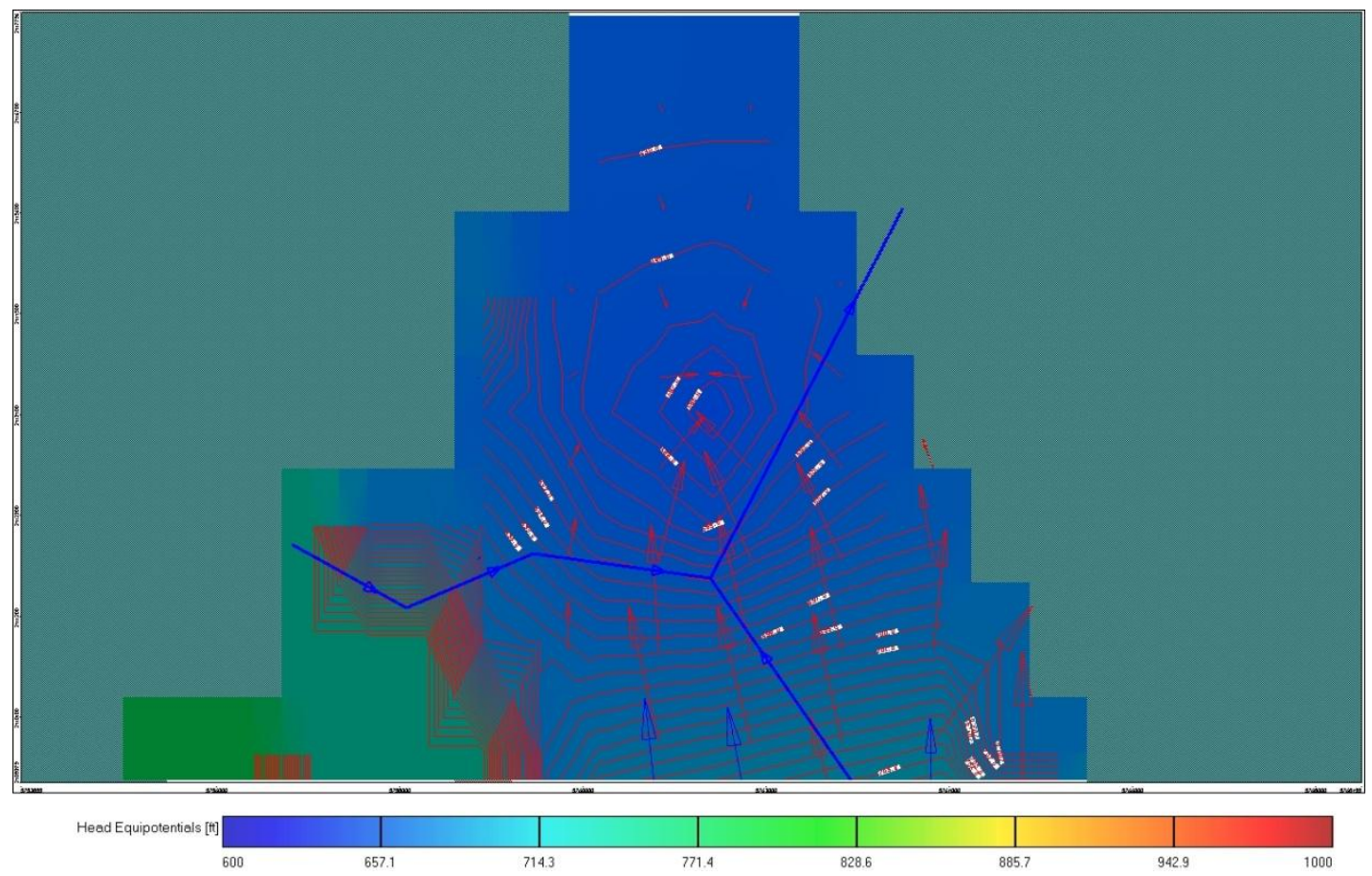

Figure $57.10 \%$ increase in pumping in October 2009 showing additional drawdown and influence near Paso Robles in Layer 1

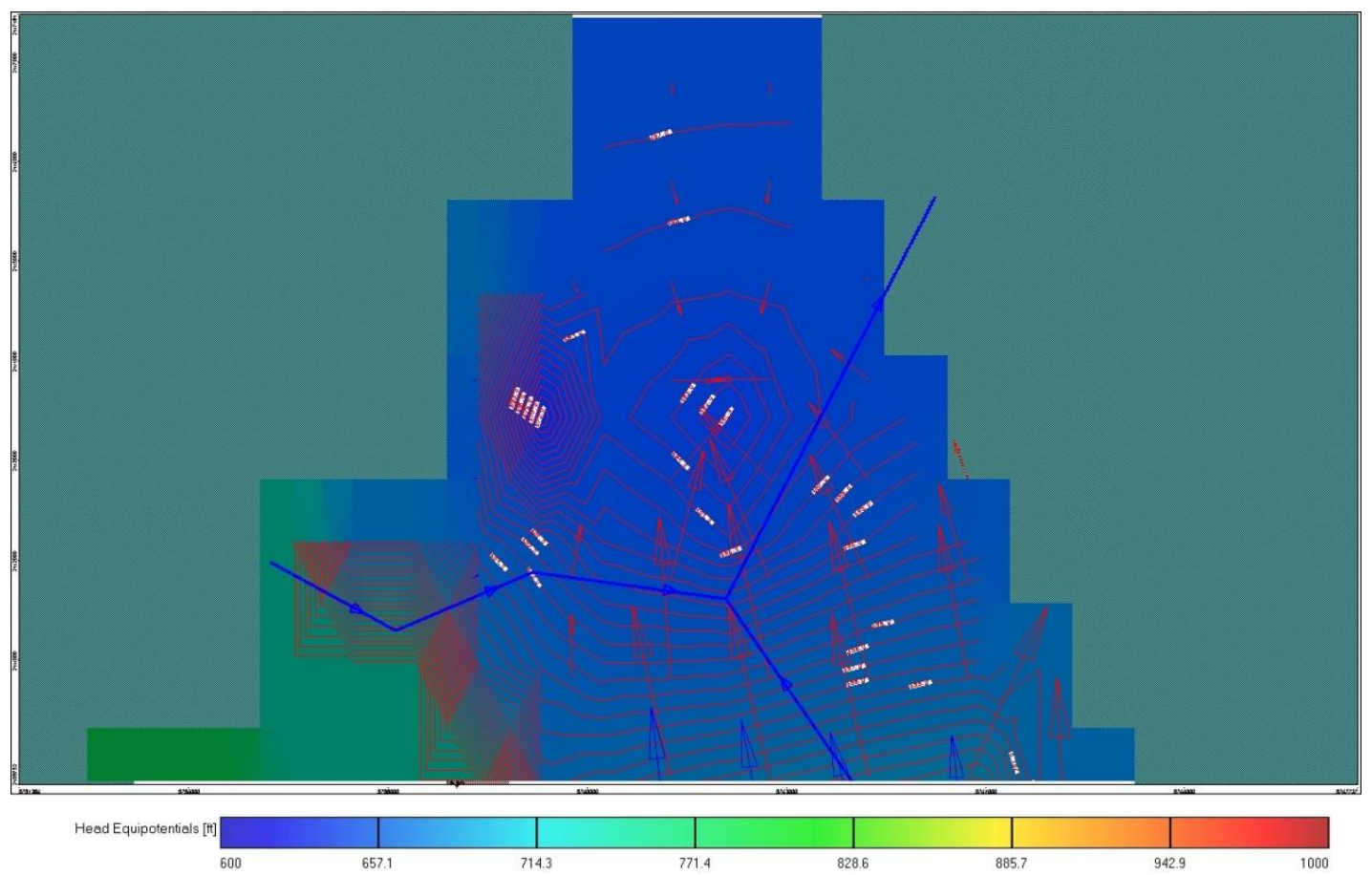

Figure 58. 20\% increase in pumping in October 2009 showing additional drawdown and influence near Paso Robles in Layer 1 


\section{Implication of Results}

The results of the groundwater model show that some locations of the Atascadero Subbasin appear to be in a sustainable state of pumping, while other areas show significant impacts to the groundwater aquifer. The model shows that the Subbasin was in an annual cycle of high and low periods for the first half of the period, but as less recharge is available during extended dry periods in the second half of the study period, some locations began to show depressions in the groundwater table. This issue was confirmed when pumping rates were increased by $10 \%$ and $20 \%$. However, not all areas saw significant increases in either drawdown or recharge. Instead the model is showing portions of the Atascadero Subbasin to be fairly consistent with some higher heads resulting in the wet winter of 2005 and slightly lower heads after the dry period from 2007 to 2009.

In the shallow alluvium, direction of groundwater flow followed the path of the Salinas River, which is typical of river underflow. In low or non-pumping areas or in wet periods this flow direction was uninterrupted. During dry periods, the flow gradient was directed towards wells in areas along the Salinas River, confirming that the shallow wells near the Salinas River do pump river underflow.

The change in head contours between the alluvium layer (1) and the Paso Robles Formation layer (3) are very similar in most of the model with the exception of the area around the city of Paso Robles. With heads to both layers changing similar amounts over a period, and the heads being larger in the alluvium than the Paso Robles Formation, it is believed there is a connection between the two layers and that some recharge occurs to the deeper aquifer. In the case of the Paso Robles area, where the head in the deeper 
aquifer is larger than the head in the alluvium, there are two possible explanations regarding the interaction. The first is that the deeper aquifer is truly confined and its recharge comes from sources higher in the hills surrounding the valley instead of from the alluvium above, and the second is the two aquifers are connected and when significant pumping occurs in the area, the shallow wells may produce both river underflow and deeper groundwater, if confining pressure creates a vertically upward groundwater gradient..

These results lead to the conclusion that currently the Atascadero Subbasin is not in a state of overdraft from pumping by the City of Paso Robles, Templeton CSD, and AMWC, as significant amounts of water pumped in the alluvium appear to originate from the Salinas River underflow. However, some localized regions may be pumped at unsustainable levels which can affect the status of the Subbasin with changes in recharge and/or production quantities. Even with some regions appearing to be sustainable, finding and implementing a surface water source (such as the Nacimiento Project referred to in the Furgo \& Cleath Report) is recommended to allow for a larger and more reliable water supply for the area 


\section{CHAPTER 7: CONCLUSIONS \& RECOMMENDATIONS}

In concluding the analysis, this groundwater model shows that portions of the Atascadero Subbasin are not in a state of overdraft, but some regions may be beginning to reach unsustainable levels. In determining this outcome, surface and groundwater models were coupled to address two goals.

The first goal of this study was to determine and model the interaction between the Salinas River alluvium and Paso Robles Formation. Head contours were compared between the two layers. In a large portion of the Subbasin head contours were larger in the alluvium than in the Formation below and their change at different periods were very similar, which lead to the conclusion that there is an interaction between the two geologic layers and generally it tends to be the alluvium recharging the Paso Robles Formation. In some regions, however, there appears to be more disconnect between the unconfined and confined aquifers.

The second goal of the study was to determine what impact the shallow pumping wells had on the groundwater aquifer. Head contours and groundwater flow direction for both the alluvium (Layer 1) and Paso Robles Formation (Layer 3) were analyzed in locations that had pumping near the Salinas River. Flow directions in the alluvium confirmed that shallow wells pumped river underflow. The magnitude depends on whether pumping is occurring in a wet or dry period, but flow direction arrows show flow into the layer from the Salinas River towards a pumping well. This model shows that the shallow wells do not pump from the deeper groundwater aquifer or draw water up to the 
alluvium to meet pumping needs. Head contours confirmed the conclusions made by the flow direction arrows. Groundwater flows from higher levels to lower and at pumping wells, the heads were lower than those surrounding them, thus creating a direction of flow to the well. With this result, it is suggested that future water budgets for the Subbasin may need to account for shallow pumping wells differently than the pumping wells that penetrate to the deeper aquifer in the Paso Robles Formation.

Overall, this study shows success in coupling a surface water model with a groundwater model to achieve an analysis of groundwater pumping near a river. Although limitations did arise in the modeling software used, a framework for coupled models has been formed and improvements can be made in future analyses. Different model parameters, input data or coupling models with different techniques can be used to further examine the Atascadero Subbasin or any other locations that have both groundwater pumping with nearby influence from a lake, river, or stream.

\section{Recommendation for Future Work}

Given the conclusions from this model, future analysis is still recommended for the Atascadero Subbasin. While this model had acceptable fits to the observed data, several assumptions were made and available data are lacking for the entire Subbasin.

First, this analysis should be repeated every few years as a check on the sustainable status of the Subbasin as the population grows and newer and larger water supply wells are installed and brought into operation. In these future analyses it is also suggested to use a smaller study period to allow for more stress periods within that time. Limiting the model to a couple years could allow for daily or weekly stress periods that would allow for better simulation of peak flows from the Salinas River. In this model the 
flows are averaged by month which reduces the contrast of large flows in the river. If a better analysis of the river interaction is desired then smaller stress periods would be preferred.

Several assumptions were made to account for the lack of monitoring well data. Finding more monitoring well data would help to improve the calibration process as the model would have a better understanding of the existing conditions it is trying to match. Also better coverage with these monitoring wells would allow for analysis to be done on the entire Atascadero Subbasin instead of the portion from Atascadero north. Additional stream monitoring by building new stream gages would help the river analysis. Having data to calibrate the flows generated by HEC-HMS would create more reliability in the runoff flows produced.

A new package or model software that can account for drawdown at a well could be beneficial. If a model could understand when a well was pumping and account for drawdown at the well, the issue of needing observation data only at non-pumping wells could be alleviated. This would also generate a better picture of where drawdown is at its worst and analyze how much each well influences one another, especially since several of the wells in the current model are very close together.

Finally, it is recommended that the percolation rate given from the HEC-HMS model be studied further. The 10 inch average amount of precipitation that makes it to recharge appears to be high. This is approximately $65 \%$ of the precipitation. $10-20 \%$ tends to be the expected percentage range. 


\section{BIBLIOGRAPHY}

American Water Works Association. "Your Water Utility." Water Use Statistics. 1999. Web. Spring 2012. <http://www.drinktap.org/>.

Braaten, R., and G. Gates. "Groundwater-surface Water Interaction in Inland New South Wales: A Scoping Study." Water Science and Technology 48.7 (2003): 215-24. Print.

California Data Exchange Center. California Department of Water Resources. Web. 5 Feb. 2011. <http://cdec.water.ca.gov/>.

California Department of Water Resources. California's Groundwater Update 2003. Rep. California Department of Water Resources, 2003. Web. Spring 2012.

CIMIS - California Irrigation Management Information System. California Department of Water Resources. Web. 20 Feb. 2011. $\langle$ http://wwwcimis.water.ca.gov/cimis/welcome.jsp>.

Eslamian, Saeid. "A Review on Interaction of Groundwater and Surface Water." International Journal of Water 5.2 (2009): 89-99. Print.

Fleming, Matthew J., and James H. Doan. HEC-GeoHMS Geospatial Hydrologic Modeling Extension. Rep. V. 4.2 ed. Davis: U.S. Army Corps of Engineers, 2009. Print.

Fleming, Matt, and Vincent Neary. "Continuous Hydrologic Modeling Study with the Hydrologic Modeling System." Journal of Hydrologic Engineering 9.3 (2004): 175-83. Print.

Fugro West, INC. Paso Robles Groundwater Basin Water Balance Review and Update. Rep. 2010. Print.

Fugro West, INC. and Cleath and Associates. Paso Robles Groundwater Basin Study Phase 1. Rep. 2002. Print.

Fugro West, INC. and Cleath and Associates. Paso Robles Groundwater Basin Study Phase 2. Rep. 2005. Print.

GEOSCIENCE Support Services, Inc. Ground Water Flow and Solute Transport Model for a Portion of the Atascadero Subbasin. Rep. 2009. Print.

Graton, Kari. "SLO County Department of Public Works - Salinas Stream Gage." Fall 2010. E-mail. 
"Groundwater Use in the United States." Groundwater Use, the USGS Water Science School. Web. Spring 2012. <http://ga.water.usgs.gov/edu/wugw.html>.

Harbaugh, A. W. MODFLOW-2005, the U.S. Geological Survey Modular Ground-Water Model - the Ground-Water Flow Process. U.S. Geological Survey Techniques and Methods 6-A16. Reston, Virginia. U.S. Geological Survey, 2005.

Langhoff, Jesper H., Keld R. Rasmussen, and Steen Christiensen. "Quantification and Regionalization of Groundwater-surface Water Interaction along an Alluvial Stream." Journal of Hydrology 320 (2006): 342-58. Print.

Muleta, Misgana. "HEC-HMS." CE 536. Cal Poly, San Luis Obispo, CA. Jan.-Feb. 2011. Lecture.

Muleta, Misgana K. "Improving Model Performance Using Season Based Evaluation." (2011). Print.

Neil, John. Atascadero Pumping Information.” Personal Interview. Feb. 2011.

Owor, M., R. Taylor, J. Thompson, C. Mukwaya, and C. Tindimugaya. "Monitoring Groundwater-surface Water Interaction in the Upper Nile Basin of Uganda." Groundwater and Climate in Africa 334.334 (2009): 68-75. Print.

Ruud, Nels. "Paso Robles Groundwater Basin Information Gathering." Phone Interview. Feb. 2011.

Scharffenberg, William A., and Matthew J. Fleming. Hydrologic Modeling System HECHMS User's Manual. Rep. V. 3.5 ed. Washington D.C.: U.S. Army Corps of Engineers, 2010. Print.

Schuldt, Carol. “GIS Layer Help.” Personal Interview. Oct. 2010.

Seamless Data Warehouse. Web. 6 Feb. 2011. <http://seamless.usgs.gov/>.

SLO County Water. Web. Jan. 2011. <http://www.slocountywater.org/>.

Soil Data Mart - Home. U.S. Geological Survey. Web. 15 Jan. 2011. $<$ http://soildatamart.nrcs.usda.gov/>.

Sorensen, Paul. "Paso Robles Groundwater Basin Information Gathering." Personal interviews. Summer 2010.

USGS. "USGS Circular 1344: Estimated Use of Water in the United States in 2005." USGS Circular 1344: Estimated Use of Water in the United States in 2005. N.p., n.d. Web. Spring 2012. <http://pubs.usgs.gov/circ/1344/>. 
"USGS Water Resources: USGS Water Data Discovery." USGS Water Resources of the United States. Web. 8 Feb. 2011. <http://water.usgs.gov/data/>.

Visual Modflow Pro User's Manual: The Industry Standard for 3D Groundwater Flow and Contaminant Transport Modelling. [S.1.]: Waterloo Hydrogeologic, 2004. Print.

WinPest User's Manual: Non-linear Parameter Estimation and Predictive Analysis Program. [S.1.]: Watermark Numerical Computing \& Waterloo Hydrogeologic, 1999. Print.

Zhang, Yingqi, Susan Hubbard, and Stefan Finsterle. "Factors Governing Sustainable Groundwater Pumping near a River." Groundwater 49.3 (2011): 432-44. Print. 


\section{APPENDICES}

Example Streamflow input for Stream Boundary Condition in Visual MODFLOW.

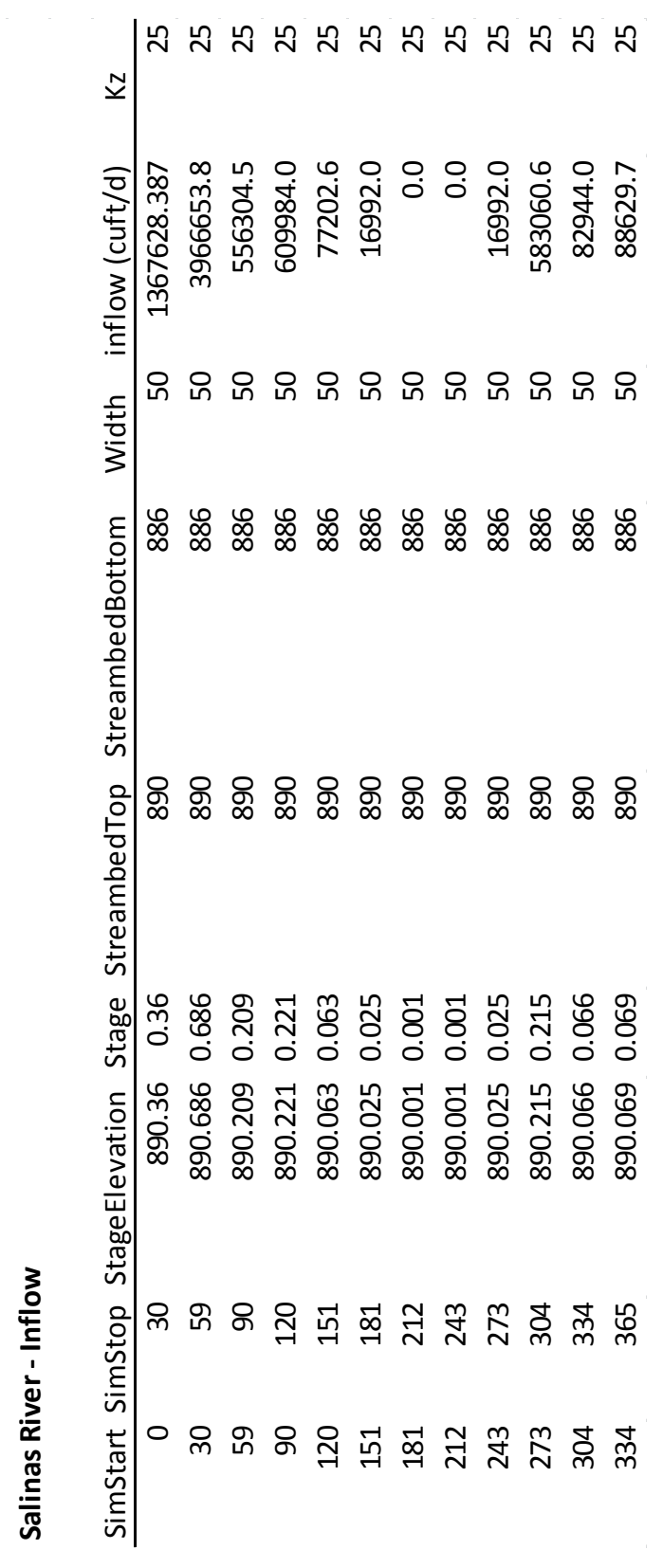

